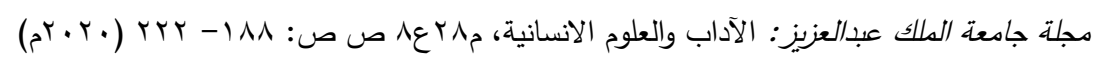

DOI:10.4197/Art.28-8.7

\title{
المقامة البغداديّة لبديع الزمان الهمذاني دراسة نقديّة تطبيقيّة في ضوء نظريّة الاتصّال الأدبي
}

\author{
د. ساري بن محمد الزهراني

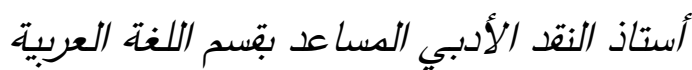

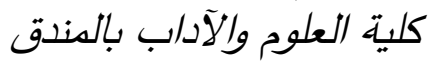 \\ جامعة الباحة
}

مستخلص. يناقش هذا البحث بالنّّد والتّحليل نص "المقامة البغدادية" لبديع الزمان الهمذاني، في ضوء نظرية

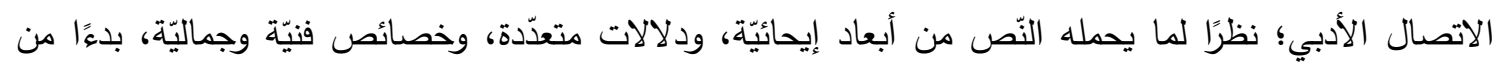

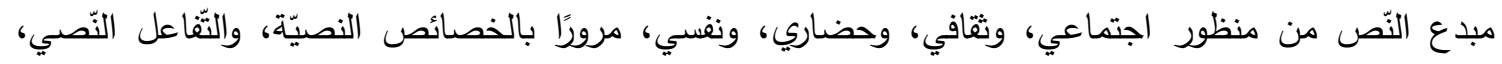

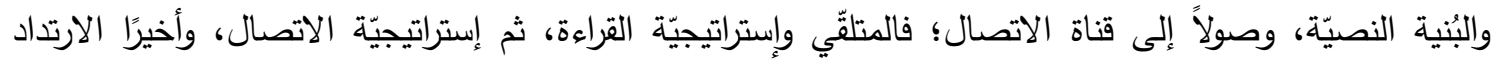

كما يناقش هذا البحث العلاقة القائمة ما بين المؤلف بوصفه منتج النّص، والنّص باعتباره مرآة للواقع الاجتماعي في منتصف القرن الرابع الهجري، وذلك وفقًا لمعايير نظرية الاتصال الأدبي؛ نظرًا لاهتمادها بالمبدع، والنّص، والمتلقّي. وخلص البحث إلى وجود علاقة قويّة ما بين الرؤية التكوينيّة لبديع الزمان الهمذاني، والبينينة النصيّة والاجتماعيّة

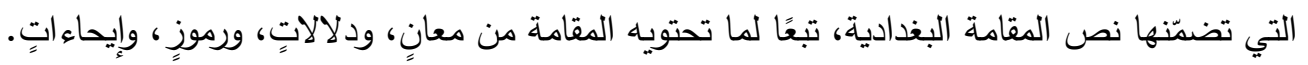

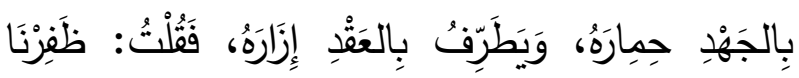

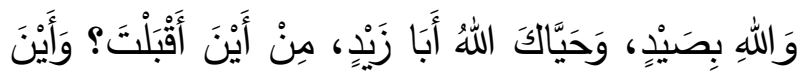

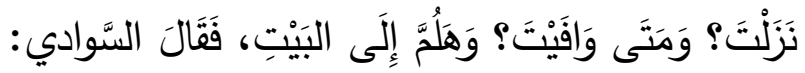

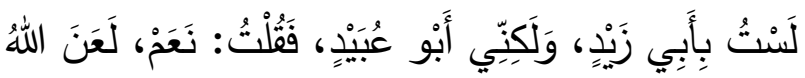

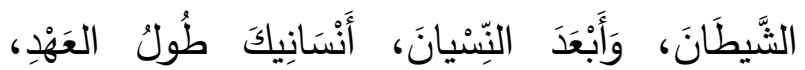

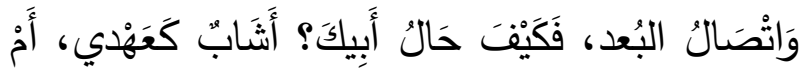

المقامة البغداديّة (1)

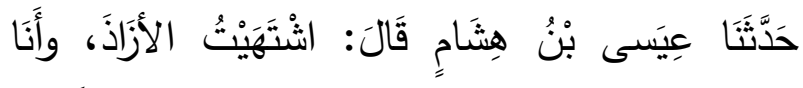

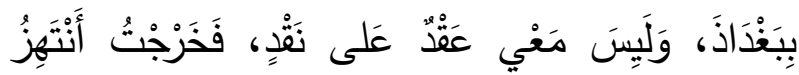

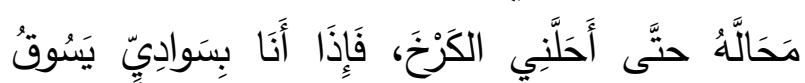

د) (1) محمد عبده، مقامات بديع الزمان الهمذاني، (القاهرة: دار الفضيلة، 


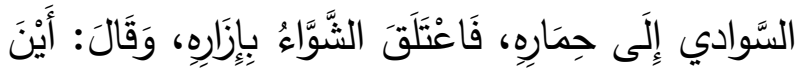

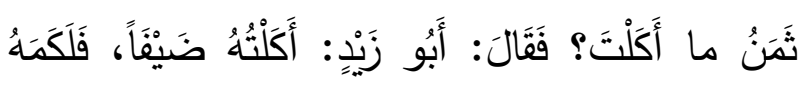

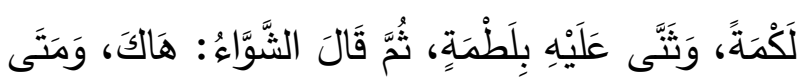

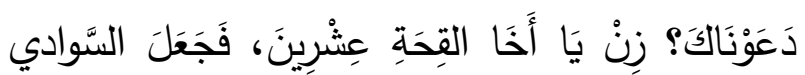

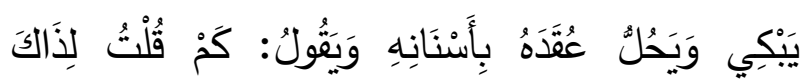

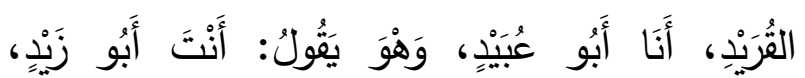
فَأَنَشَنْتُ :

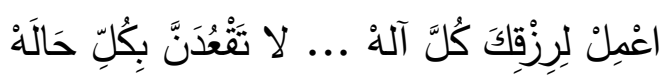

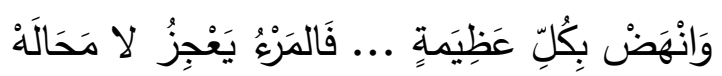

\section{المقدّمة}

تعتبر المقامة فنَّا أدبيَّا يتّذذ من البناء الحكائي

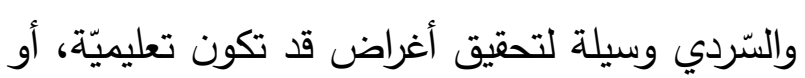
اجتماعيّة، أو سياسيّة، وتمتاز عادة بينيتها الفنيّة

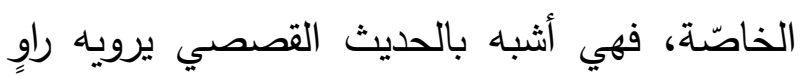
بليغ، ظريف، يتوسّل الاحتيال، ويتقن الخداع؛ باعِ

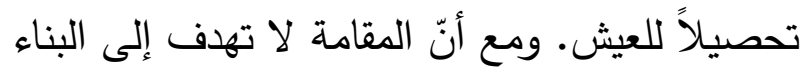

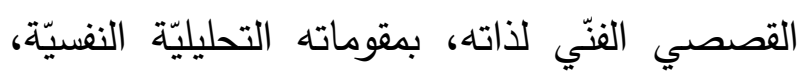

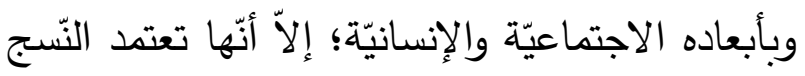

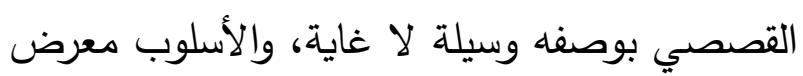

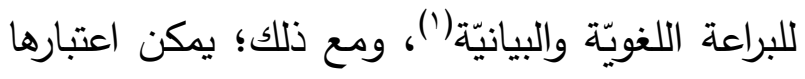

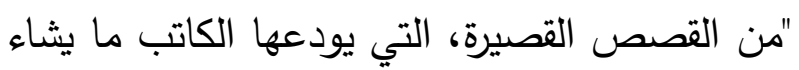
من فكرة أدبية أو فلسفية أو نظرة وجدانية أو لمحة

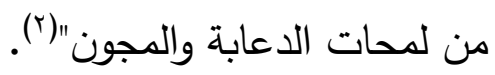

(1) بنظر : إميل بديع يعقوب، المعجم المفصل في اللغة والأدب، (بيروت:

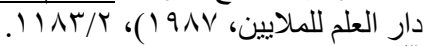

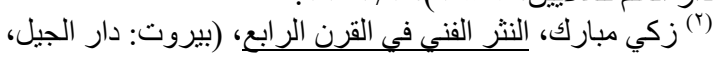

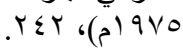

شَابَ بَعْدِي؟ فَفَالَ: قَدْ نَبَتَ الرَّبِيعُ عَلَى دِمْنَتِهِ، وَأَرْجُو

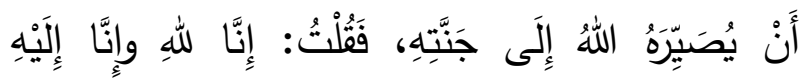

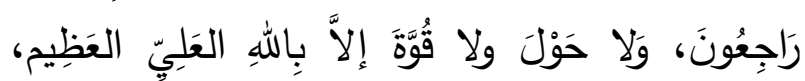

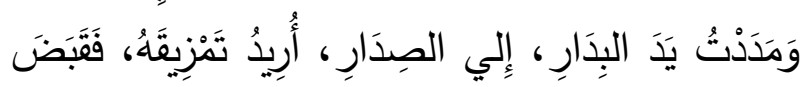

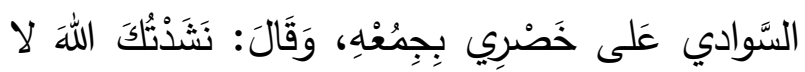

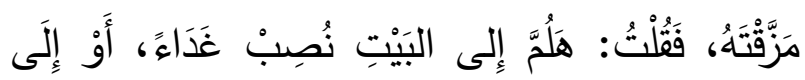

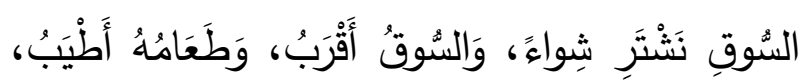

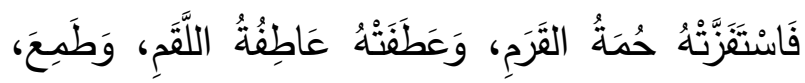

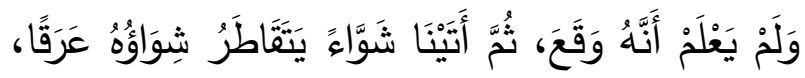

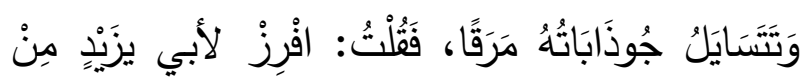

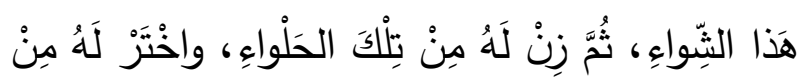

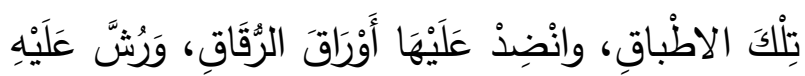

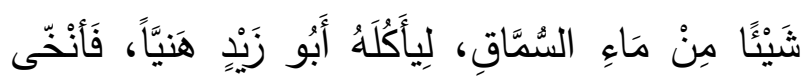

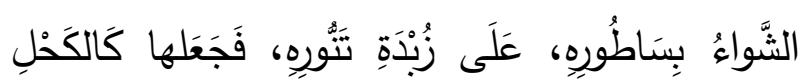

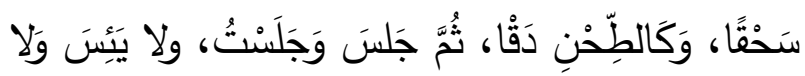

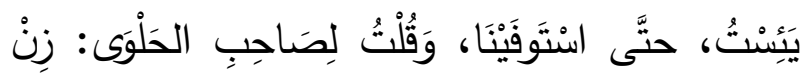

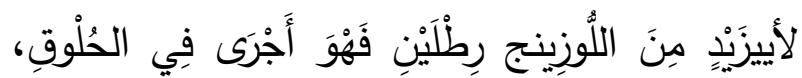

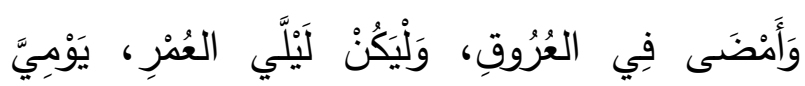

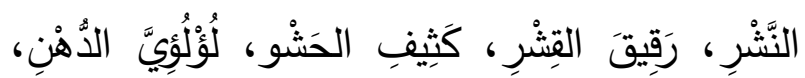

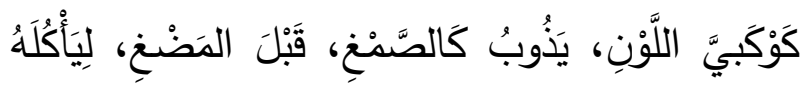

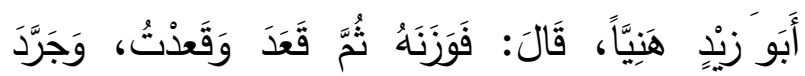

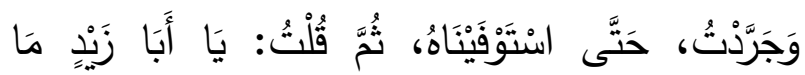

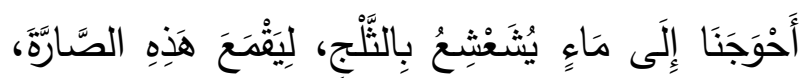

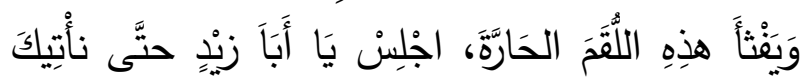

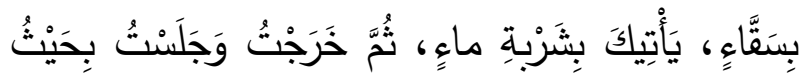

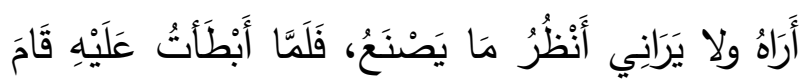


ولعلّ مشكلة الدراسة تكمن في قلّة الدراسات النقديّة التي عنيت بالنّص النثري عمومًا، وبفنّ المقامة

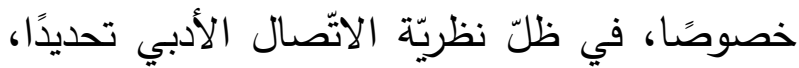
ولهذا يسعى البحث إلى دراسة نص المقامة البغداديّة

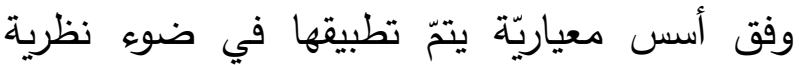

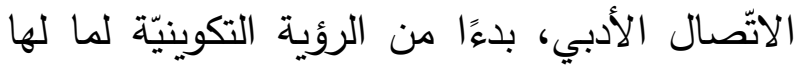

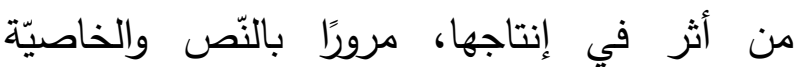
النوعيّة، فالتقاعل النّصي، ثِّ الوسيلة الاتصاليّة،

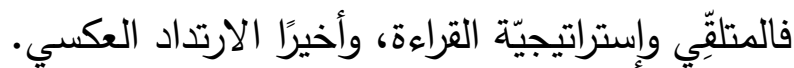

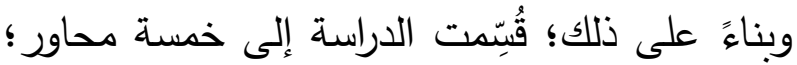

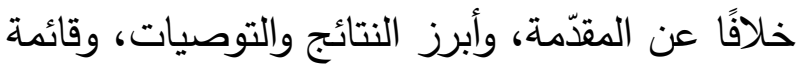

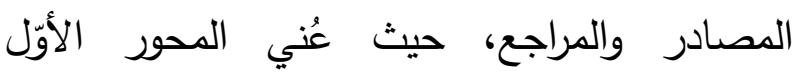
بالمبدع من حيث الرؤية التكوينيّة، أمّا المحور الثاني

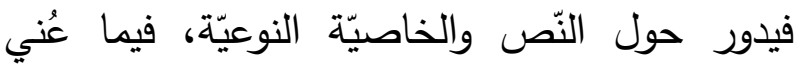
المحور الثالث بالوسيلة الاتِّصاليّة، في حين يرتبط

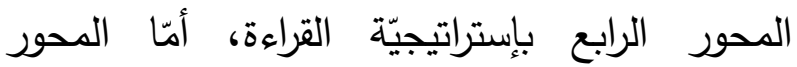
الخامس فيدور حول الارتداد العكسي.

\section{1- المباع والرؤية التكوينيّة}

يُعدُّ المبدع، أو المؤلّف، أو منتج النّص هو مركز

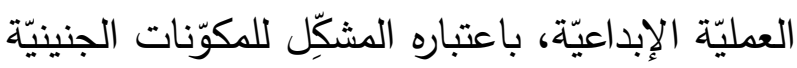
للنّص حتى يصل إلى المتلقّي؛ لأنّه المسؤول الأوّل

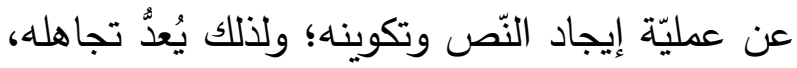
أو تجاوزه إلى النّص بمعزلٍ عن السّياق الذي تولّّد

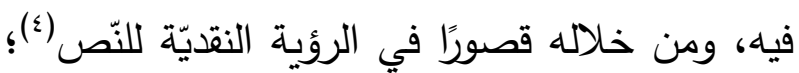

(\$) ينظر: مبروك، عبدالله، ضباب، نظرية الاتصال الأدبي بين التنظير

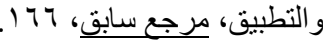

ونظرًا لما تتمتّع به المقامة من مقومات إبداعيّة،

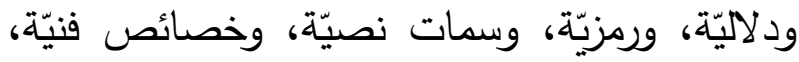
فقد اختار الباحث أن يتّجه إلى دراسة إحدى المقامات، وبالتحديد المقامة البغداديّة لبديع الزمان الهذاني، دراسة نقديّة تطبيقيّة في ضوء نظرية

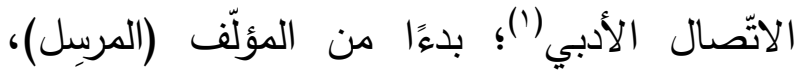

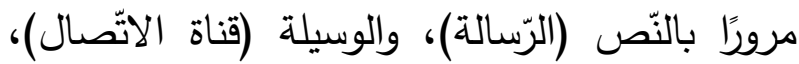
والقارئ (المرسَل إليه)، ونهاية بالارتداد العكسي،

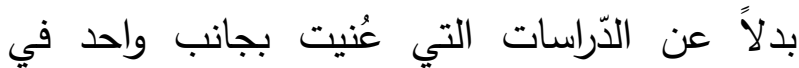
دراسة النّص، كتلك التي درست النّص بعيدًا عن محتواه، وعزلته عن التّراكيب الاجتماعيّة التي لتي

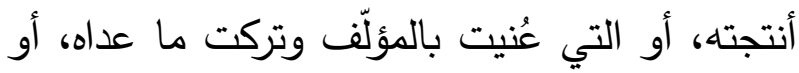

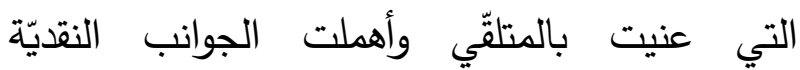

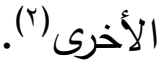

إنّ نظرية الاتصال الأدبي لا تستتد إلى المؤلّف فحسب، مثلما جنحت إلى ذلك المناهج والنظريّات النقديّة التقليديّة، ولا إلى النّص فحسب، مثلما لجأت لذلك البنيويّة الشكلانيّة بشتّى أنواعها، التي تتطلق من النّص بعيدًا عن المؤثّرات والعوامل الخارجيّة التي أثّرت في تكوينه، ولا إلى القارئ فحسب، مثلما لجأ إلى ذلك أصحاب نظريّات التلقي، والتأويل، واستجابة القارئ(r).

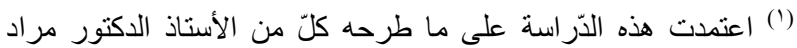

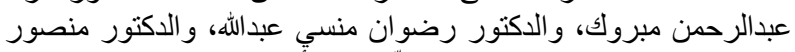

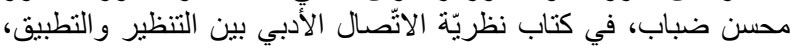

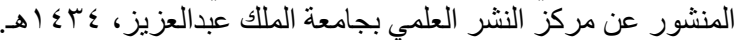

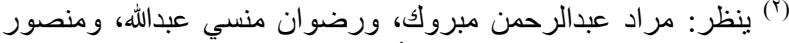

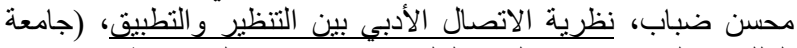

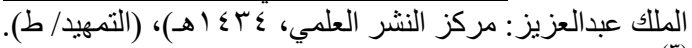
(") ينظر : الدصدر الستّابق، (التمهيد/ط). 
في وعيه المعرفي، وفي نتاجه الأدبي. ولعلّ نشأته

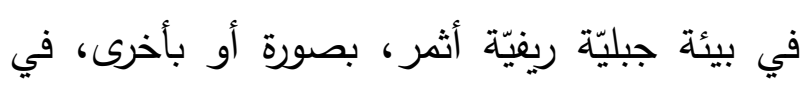
تشكيل شخصيته، وهو ما انعكس على مسيرته الحياتيّة مستقبلاً. ولعلّ أوّل ملحوظة قد تصادف الباحث، ذلك التّزامن ما بين ولادة بديع الزمان وقيام دولة البويهيين؛ عطفًا

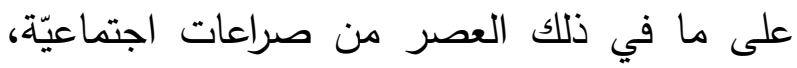

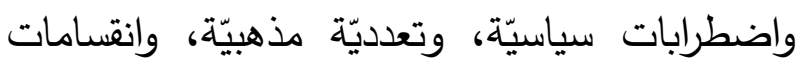
طائفيّة، إضافة إلى حضور الكثير من الأفكار، والمعتقدات، والنّزعات ما بين الولاة، وكلّ ذلك كان له أكبر الأثر في تثكيل وعيه المعرفي، والثقافي،

$$
\text { والاجتماعي (r). }
$$

لقد كانت همذان في تلك الفترة التي عاش فيهاعيا الهذذاني مشحونة بالكثير من الأوضاع الاجتماعيّة

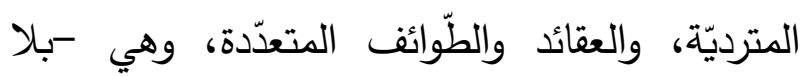

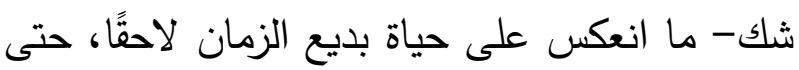

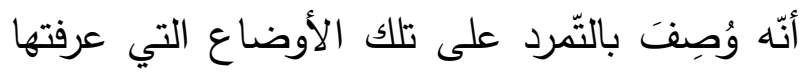
بلدته، وهو ما دفعه إلى الهجرة، وإيثار التتقل من

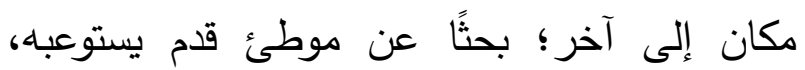

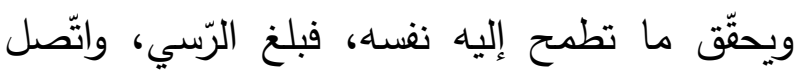

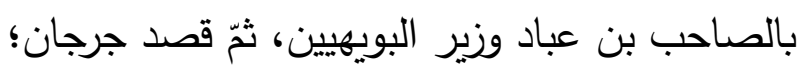
لكن سرعان ما رحل عنها، إذ أوغر بعض الحسّاد على الهذذاني، فاضطرّ إلى مغادرة جرجان قاصدًا

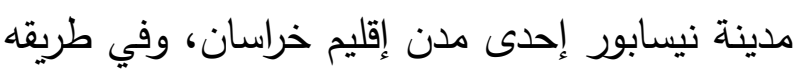

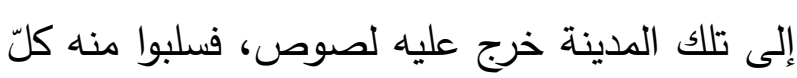

ينظر : (") المرجع السابق، نفس الجزء و الصفحة.
ولذلك يرى ميشال فوكو أنّ المؤلّف وظيفة تساعد على تتظيم عالم الخطاب، وأنّ اسم المؤلّف ينهض لهض بدور العلامة المميزة لصنف الآثار التي ألفها من تلك الآثار، التي تجهل هويّة أصحابها، أو يفتقر

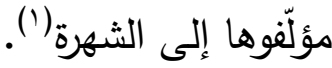
وغالبًا ما تتشكّل الرؤية التكوينيّة من: المكوّن

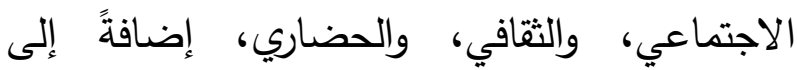
النفسي، والملاحظ أنّ جملة تلك المكوّنات تكاد تكون حاضرة، بصورة أو بأخرى، في نصوص بـ بديع

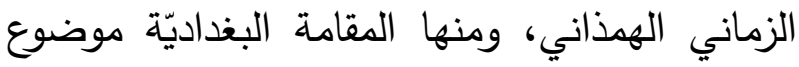
الدراسة؛ لأنّها المسؤولة عن خلق النّص وإيجاده؛ فضلاً عن أنّها تشكِّل وعي المبدع في الآن ذاته.

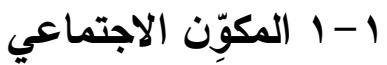

يعدّ المكوِن الاجتماعي من أبرز العوامل المشكِلة

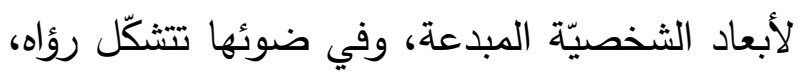
وأفكاره، وتوجّهاته؛ ولذلك يمثّل المكوّن الاجتماعي

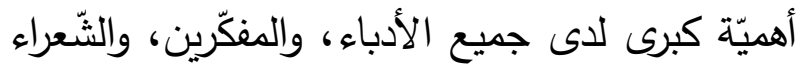
على حدٍ سواء، ومن يتتبّع نتاج هؤلاء يلحظ أنّ أغلبه الغيه كان تعبيرًا عن واقعهم الاجتماعي، وانعكاسًا له بما فيه من أزمات، وصراعات، وتتاقضات.

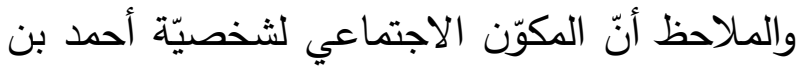
الحسن أبو الفضل، الملقّب ببديع الزمان المولود في الدي

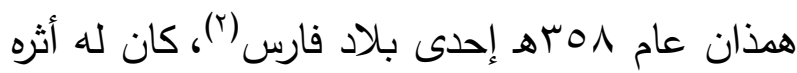

(1) ينظر : محمد القاضي، مجمد الخبو، أحمد السماري، محمد نجيب، علي عبيد، نور الدين بنخوذ، فتحي النصري، محمد آيث ميهوب معجد

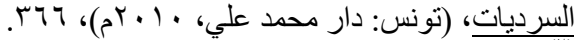

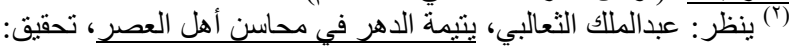

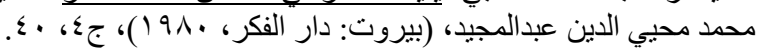


في مقابل ذلك، يذهب الثعالبي إلى وصف الهذذاني

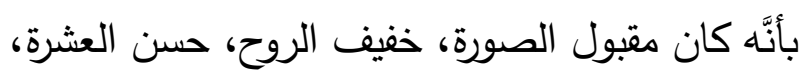

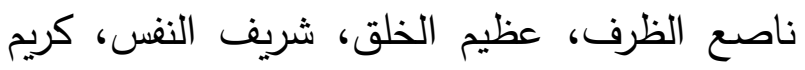

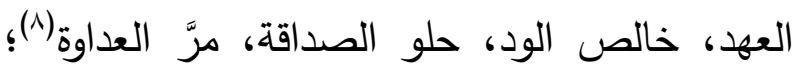

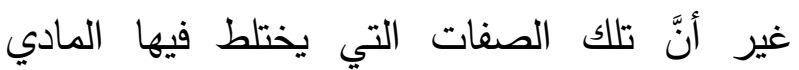
بالمعنوي تواجه بكثير من التحفظ والاعتراض؛ فقد أشار بعض مترجمي حياة الهمذاني إلى أنَّه كان سليط اللسان إلى حدِّ البذاءة، فهو "سبَّاب شتَّام همَّاز

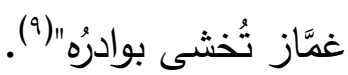

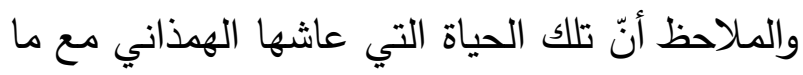
فيها من التّتقل، والتّمرد، والثّّرة، وعدم الاستقرار تكاد

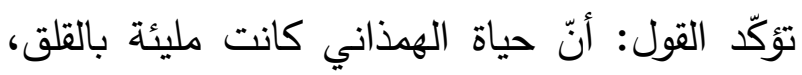
والتوتر سواء على المستوى النفسي أو الاجتماعي، وهو ما انعكس بشكل مباشر على تشكيل شخصيته

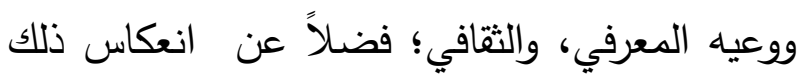
على نتاجه الفكري والأدبي، ومنها مقاماته.

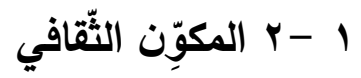
يتشكّل المكوّن الثّقافي والمعرفي لدى بديع الزمان

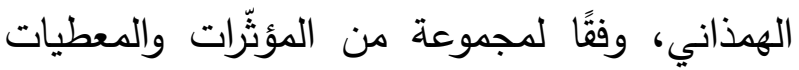

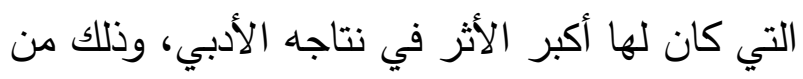

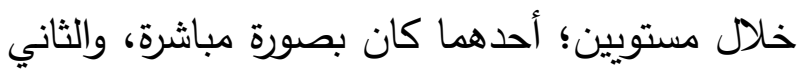
بصورة غير مباشرة. والملاحظ أنّ تأثره بأبي الحسين بن أحمد بن فارس

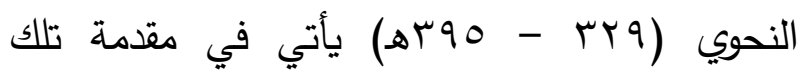

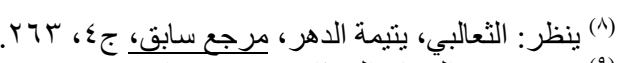

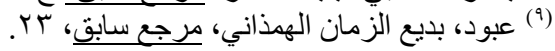

شيڤً، وقد وصف هذه الحادثة في إحدى رسائله

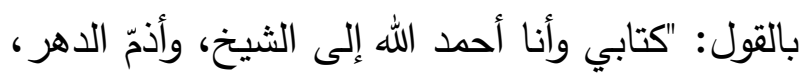

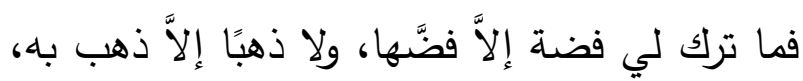

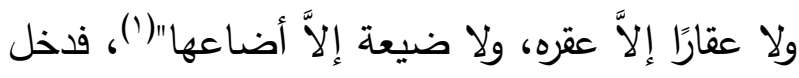
نيسابور وهو كما يقول: "ولا حلية إلاّ الجلدة، ولا بُردة

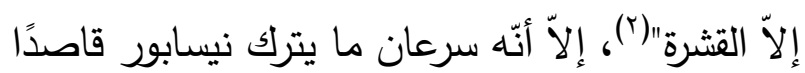
خراسان، ثّ سجستان، وغزنة، وكرمان، متكسيَّا بأدبه

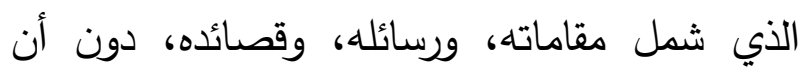
يحرم أُعْطيات أمراء هذه البلدان وحكّامها، فعاش وناث

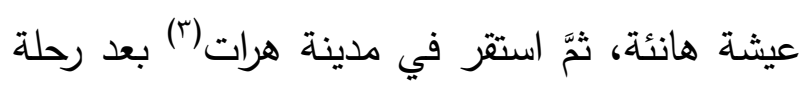

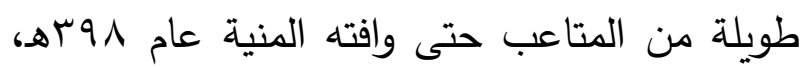
بعد أن تضاربت أسباب وفاته ما بين أصابته بسكتة قلبية) (๕)، أو الموت مسمومًا(0).

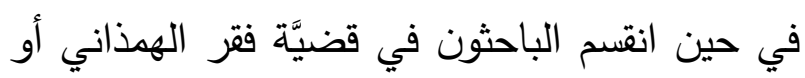

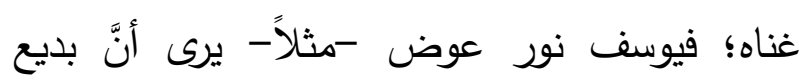

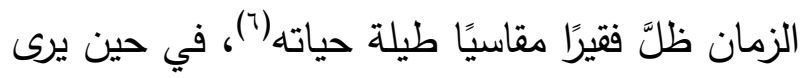

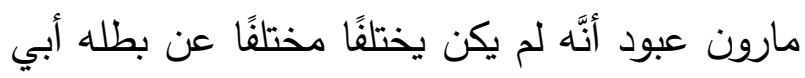

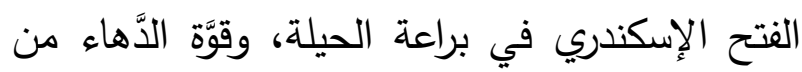
أجل تحصيل المال وكسبه دون الاهتمام بكيفية

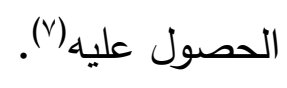

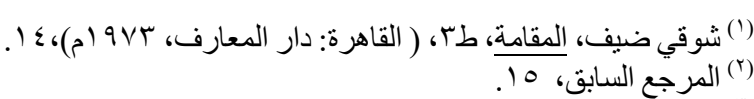
جيظر : الثعالبي، يتيمة الدهر في محاسن أهل العصر، مرجع سابق،

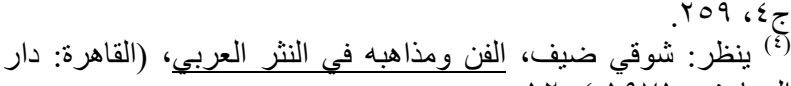

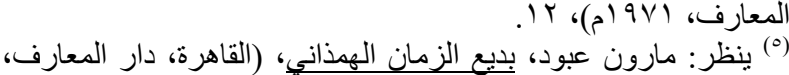

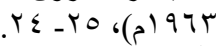

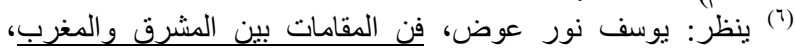

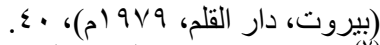

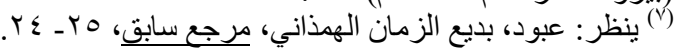


الثعالبي أن يقول عنه: "إنّه متوقد الذهن، قوي الذاكرة" (0). ولا شكَّ أنّ تلك المراحل بمعطياتها المتعدّدة، وما يصاحبها من عمليّة الاتصّال المباشر بالعلماء والأدباء، كانت في الجملة من أبرز العوامل المشكّلة

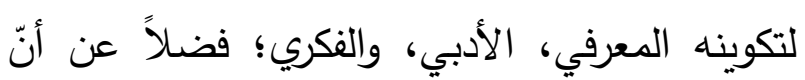
القرن الرابع الهجري نفسه كان هو الأكثر إخصابًا،

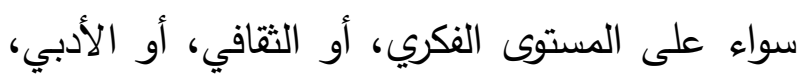
والأغنى بالإنجازات العقليّة، والأثرى في كمية النتاج النياج

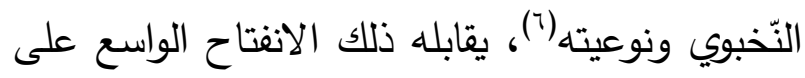

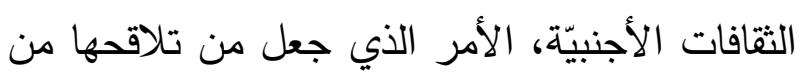

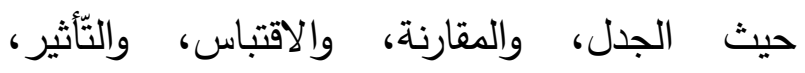
والتّأثر (v)، إضافة إلى نضـج العلوم، واستقرار أبواب

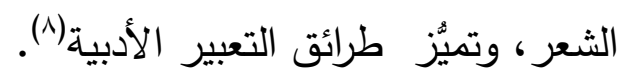

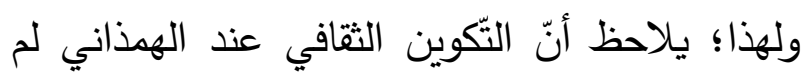
يكن وقفًا على رافد واحد؛ بل من خلال مجموعة من المن

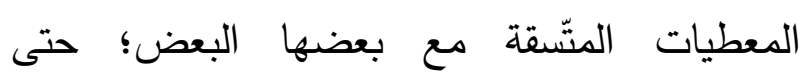

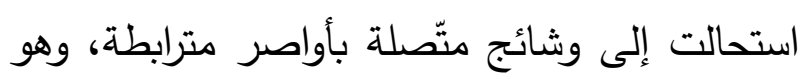
ما أدّى إلى "تميزه وتثكيل وعيه الثقافي والفكري"(9.")

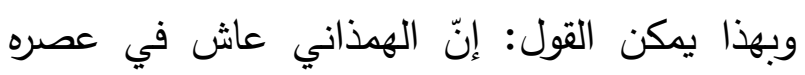
بكل تجلّياته، ومنعطفاته، وصراعاته، وتنوّع ثقافاته؛

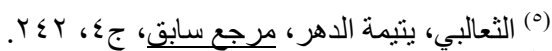

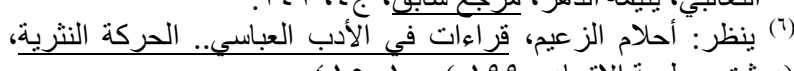

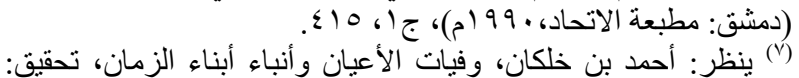

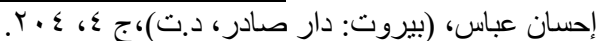

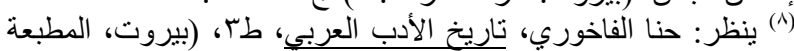

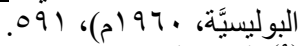

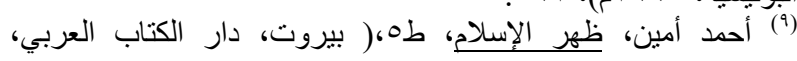

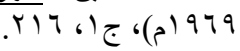

المعطيات المؤثّرة بصورة مباشرة، حيث كان له

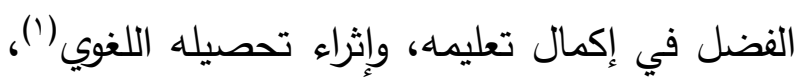
وبذلك يمكن اعتبار هذه المرحلة أولى مراحل تكوينه

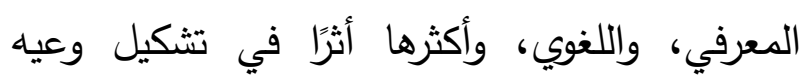
الثقافي.

في حين ترتبط المرحلة الثانية بتثكيل وعيه الأدبي، وذلك من خلال اتصاله بوزير البويهيين الأديب

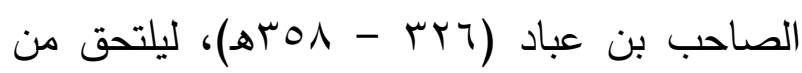

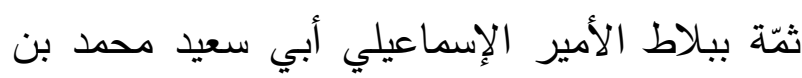

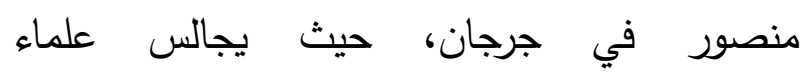
الإسماعيلية، ويعيش في أكنافهج، ويقتبس من لجن

نوادرهم (r).

غير أنّ ارتحاله إلى أبي بكر الخوارزمي (بrادب -

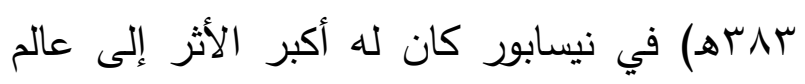

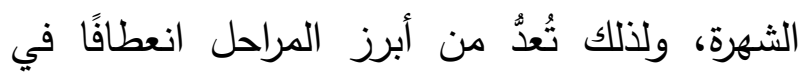

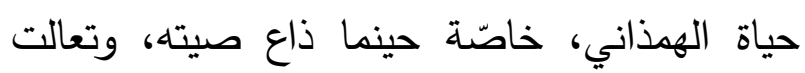

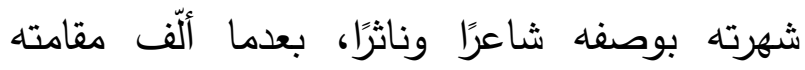

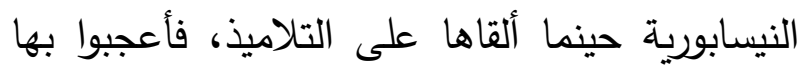

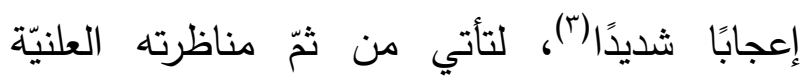
للخوارزمي عند بعض الأمراء، حيث برهن الهذذاني من خلالها على الكثير من مواهبه المتعدّدة، فاستطاع أن يجذب إليه أنظار الحاضرين، خاصصّة

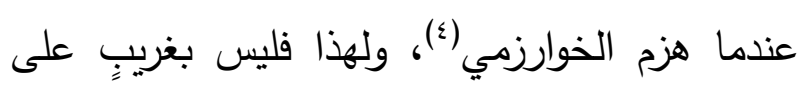

(1) ينظر: جرجي زيدان، تاريخ آداب اللغة العربية، (بيروت: دار الحياة،

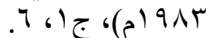

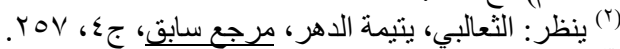

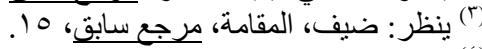

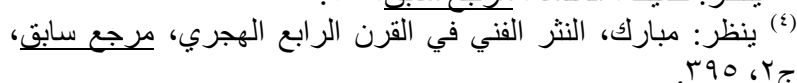


الهمذاني، وتحديدًا مع ولاية الخليفة العباسي المطيع ( )

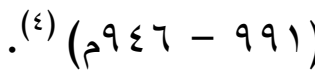

ومع ذلك؛ فقد كانت تلك الفترة التأريخيّة التي عاشها

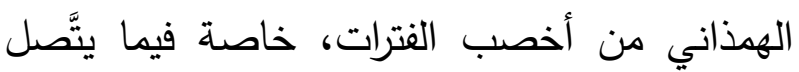
بالاضطرابات السياسيّة، والطائغيّة، والعقائديّة، وهي الدي

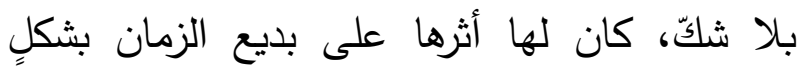

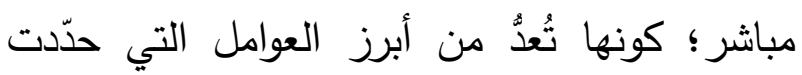
اتجّاهاته الفكريّة، وتوجّهاته الأدبية، ومنطلقًا لأفكاره وممارساته، وطريقة عيشه، خاصة أنّه شهذ قيام الدولة البويقيية بمجدها وقوّتها، كما شهد بقية حياته نهاية الدولة السّامانية على يد الغزنويين. والملاحظ أنّ المكوّن الحضاري بأبعاده السياسيّة،

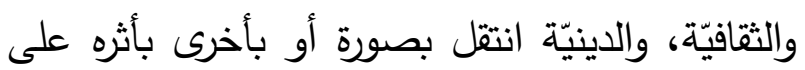

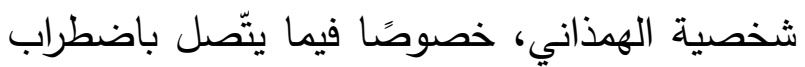

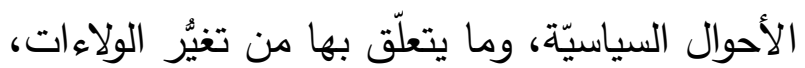

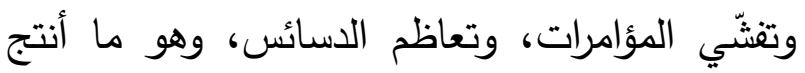
الجفاء من قِبل الحاكم الذي ينزل الهمذاني بساحته،

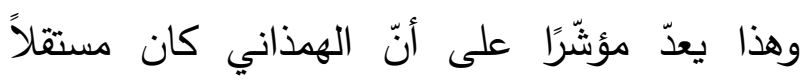

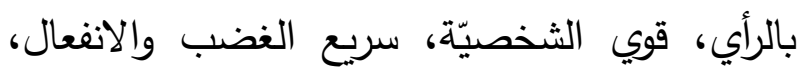
كما يشي -أيضًا- إلى أنّ الههذاني نفسه لم يكن صاحب ولاءات سياسيّة تمنعه من التتقل ما بين

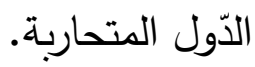

(و) ينظر: فيليب حتي، جبرائيل جبور، إدورد جرجي، تاريخ العرب،

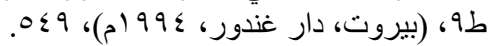

فتأثّر بها وأثّرّ، وأخذ منها وأعطته، ف"تميز بالأسلوب المسجع والمزوق بأنواع البديع"(')، واستطاع، بناءً

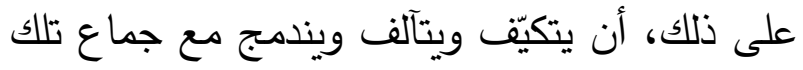
المحصلات والمعطيات؛ ليتحوّل خطابه الأدبي من ون ونه أثر ذلك إلى صورة من واقعه، وشبيه له، وهذا ما

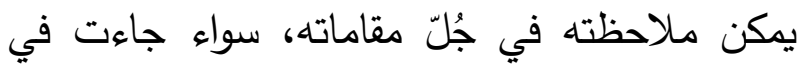
صورة الضّعيف والمحتال، أو الواعظ والداعية، مخلِّفًا وراءه تركة أدبيّة جمعت ما بين الجد والهزل فيما

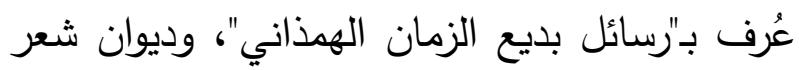
وحيد.

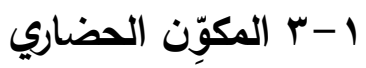

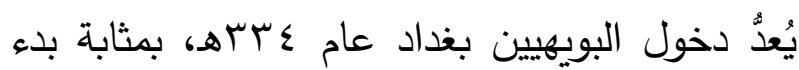

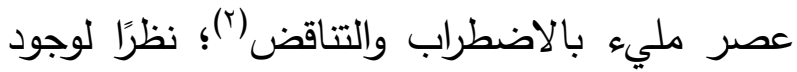
العديد من الصّراعات المذهبيّة والعقديّة، والاحتقانات

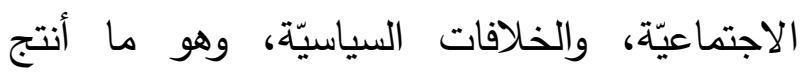

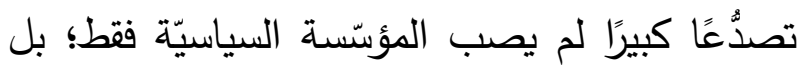
تجاوزها إلى البُنى الاجتماعيّة والاقتصاديّة، إذ فقدت ليّا مؤسّسة الخلافة العباسيّة دورها القيادي تمامًا،

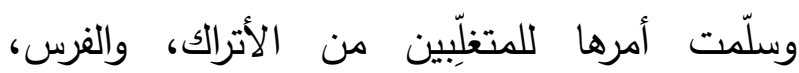

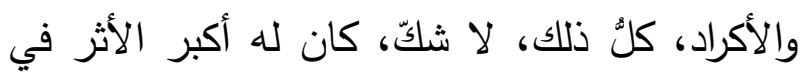

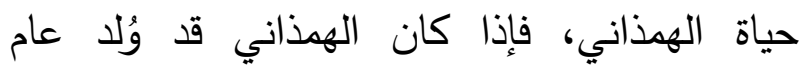

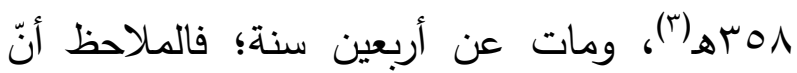

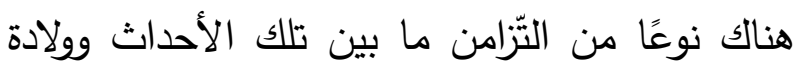

(1) الزعيم، قراءات في الأدب العباسي.. الحركة النثرية، مرجع سابق، (r) بنظر: أحمد حسن الزيات، تاريخ الأدب العربي، (القاهرة، دار

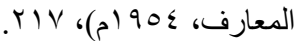

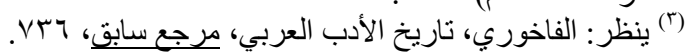


بئست الكتب وما وسقت، والأقلام وما نسقت، والمحابر وما سقت، والأسجاع إذا اتسقت" ('). إنّ رحلة البحث عن الذّات كما يلاحظ على بديع

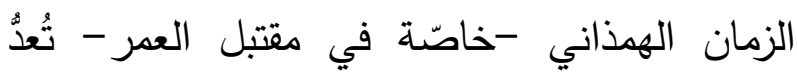
مؤشرَ قلقٍ، وحيرةٍ، واضطرابٍ، وصراع؛ بل دليلاً

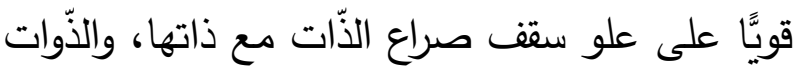

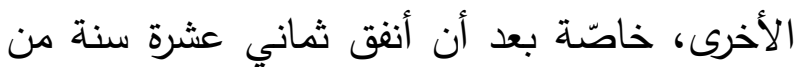
عمره في رحلة لا تعرف السكينة والهدوء.

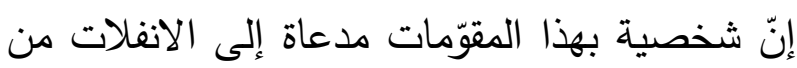
خطام الاستقرار والثّبات، وهذا بدوره ما انعكس بشكلٍ مباشر على شخصيته، وذلك من خلال ما يصدر

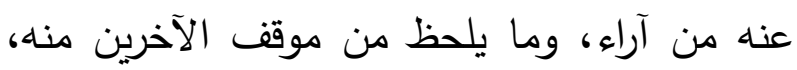
وهذا ما يمكن ملاحظته حينما وصف تارة بالانتهازي، وتارة بأنّه متقلب الرأي، ومرّة بالحسد

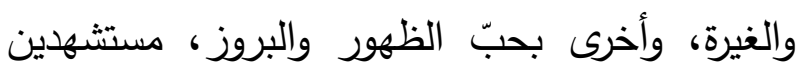

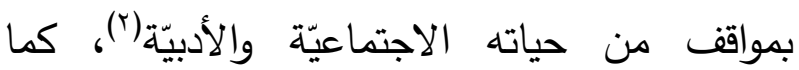
يلاحظ في المقامة الجاحظية حينما وضع نفسه فوق الجاحظ(")، ولذلك ليس بالغريب أن يكون بطله هو نفسه في مقاماته، وأنّ الرجل لم يختلف عمّا

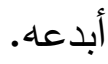

ومع حضور تلك النبّرة التي تقف خصمًا على

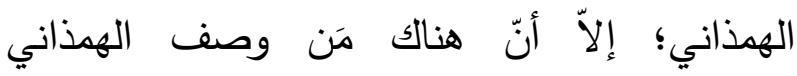
بالحسّاس والمتيقظ الذي لا يطيق أن يخضع لأحدا،

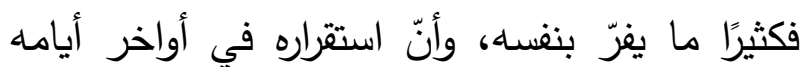

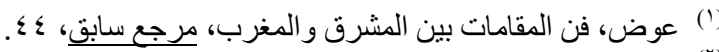

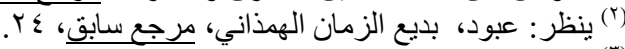

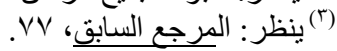

إنّ جملة تلك المكوّنات السياسيّة والحضاريّة كان لها أكبر الأثر في نتاجه الأدبي، وهو ما انعكس على

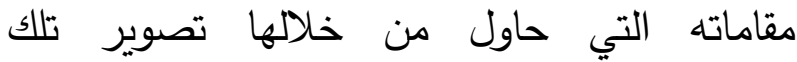
التّاقضات والصّراعات بصورة أكثر سخرة، وقد هند احتشدت بالدّلالات والمعاني، سواء كانت في صورة

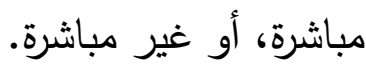

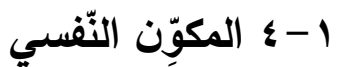
إنّ صراع الذَّات، والزََّّن، والمكان من أبرز العوامل

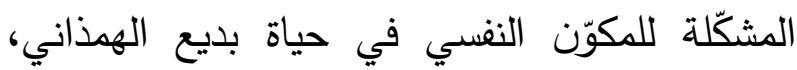

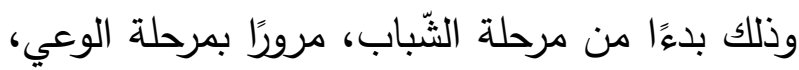
وانتهاءً بمرحلة العودة إلى مسقط رأسه. ولعلّ جملة تلك المنعطفات والتحوّلات بمثابة الأدوات الفاعلة والمؤثّرة في تشكيل الخواص النفسيّة

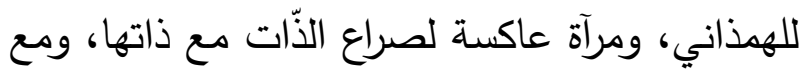
ما يحيط بها في واقعها المعاش.

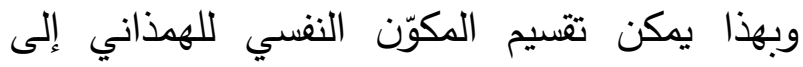
ثلاث مراحل، وكلّ مرحلة منها تتّصل بما قبلها

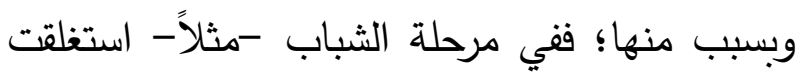
عليه نفسه، فآثر التّرحال عن بلدته، فغلب عليه التّرد والرّربة في التتقل، على اعتبار أنّ رحلات الجسد وتنقلاته مؤشرُ دالُّ على اضطرابات تتّصل بحالة الحيرة الداخليّة التي استولت عليه، ولذلك لكالك فليس بالغريب أن يُرى أثر ذلك في بعض مقولاته

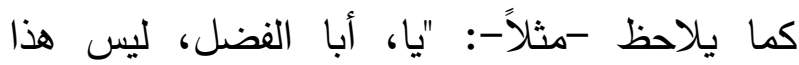
بزمانك، وليست هذه بدارك، ولا السّوق سوق متاعك، ليا 
بهرات البعيدة والنائية تكاد تشي بتلك الأسباب عن عَقْدُ عَلى نَقْدِ"، وكذا "بسَواديٍّ يَسُوقُ بِالجَهْدِ حِمِارَه"

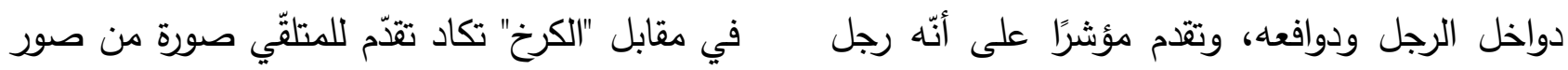

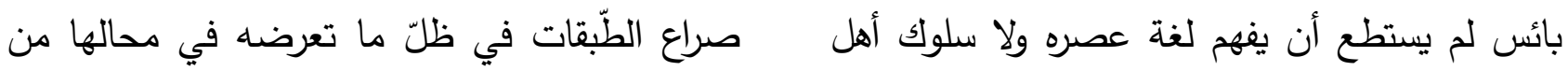

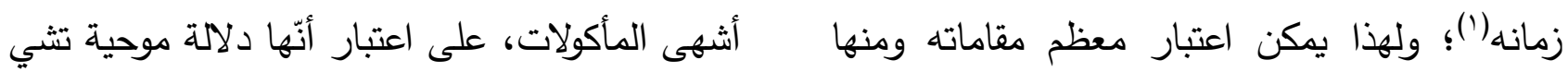

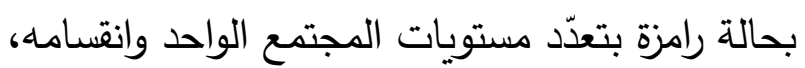
حينما جمع ما بين دلالة الفقر الذي تعيشه مجموعة

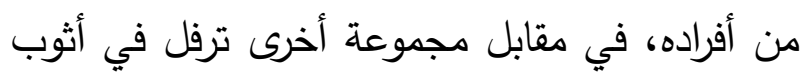

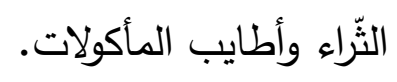

ومع ما في تلك العبارات من دلالات موحية؛ إلاّ أنّ

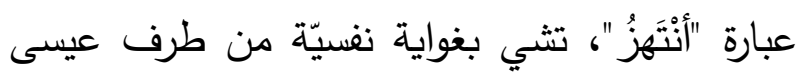

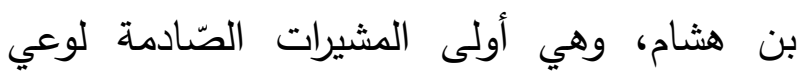
الكتلقّي، كون الدلالة التي توحي بها عبارة الانتهاز تكاد تقدّم للمتلقّي صورة الباحث عن تدبير "حيلة

$$
\text { ما"، في مقابل البحث عن "ضحية ما"! }
$$

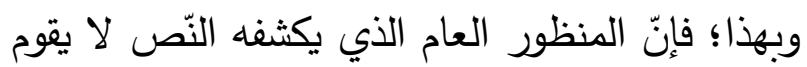

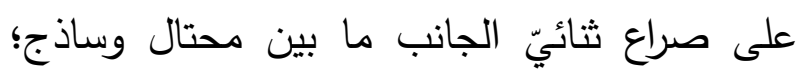

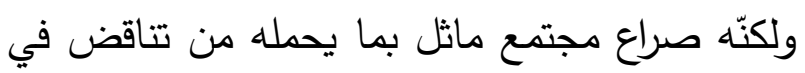

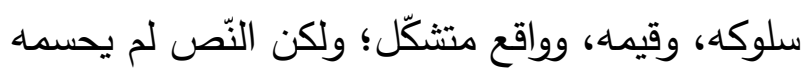
بعد. ومن هنا؛ فإنّ بؤر الصراع لمّا تزل حيّة مثالة في تلك الثنائيّة؛ لأنّ حضور تلكن بؤن الثنائية في بؤرة

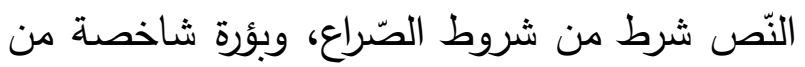

فإذا كانت المقامة تعدّ جزءًا من التراث العربي السّردي؛ فإنّها تقوم على مجموعة من المعطيات

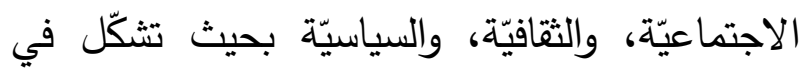
جملتها بؤرة صالحة للدّلالة على ما وصل إليه المقامة البغداديّة مرآة كاشفة عن حالاته النفسيّة والثعوريّة تجاه واقعه، وتعبيرًا عن جماع ذلك بصورة

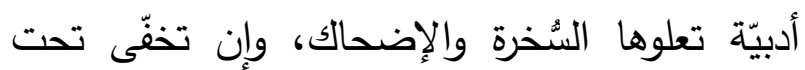
قناع بطله!! r- النَّص والخاصيَّة النوعيَّة

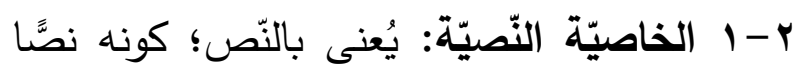

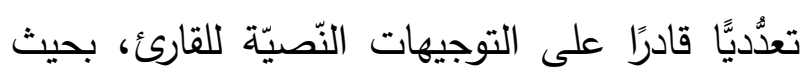

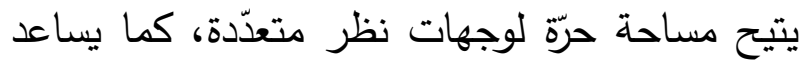

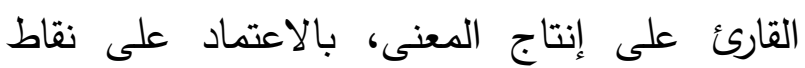
الابهام التي يملؤها المتلقيّي (r).

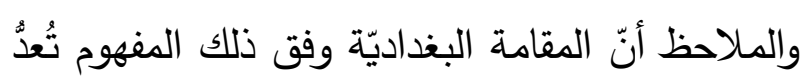
نمَّا متجدِدًا متعدّد القراءة؛ وهذا ما يمكن ملاحظته

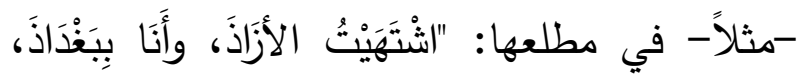

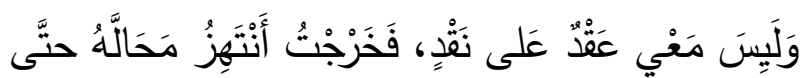

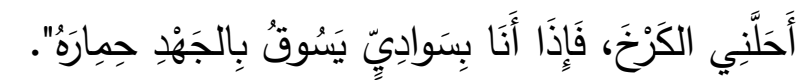

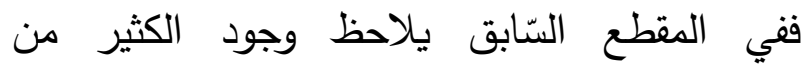
الخصائص النّصيّة قد تحقّتت، سواء من حيث الإيحاء والتّديد وإنتاج المعنى، أو من حيث مله الفراغات التي يقوم المتلقّي بملئها، وفقًا لوجهات التئات

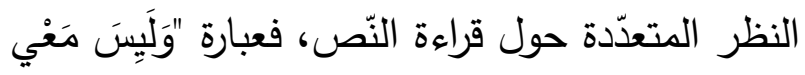


وهذا الاستدعاء الإسنادي يكاد يجعل من فن المقامة وفضائها النّصي بنية متحرّكة ضمن محيط دائري، وذلك من خلال الجمع ما بين أدب الحكاية من لنه

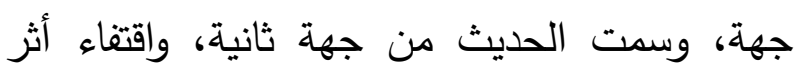
التّاريخ من جهة ثالثة.

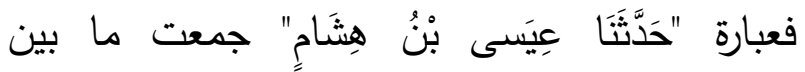
الاستدعاء والتّقاعل، وذلك حينما بنى الهذاني ذلك فئك

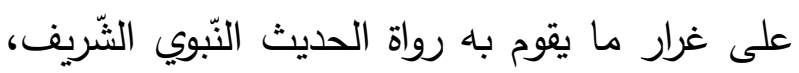

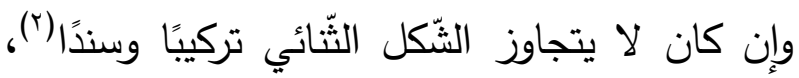
مع أنّ الهذذاني نفسه قد عمد إلى استحضار شخصية عيسى بن هشام بإيراد الاسم مركّبًا من جزء إنه

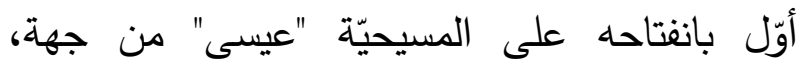
واستدعاء آخر يرتبط بالإسلام "ابن هشام" بوصفه أشهر رواة السّيرة النبويّة من جهة أخرى.

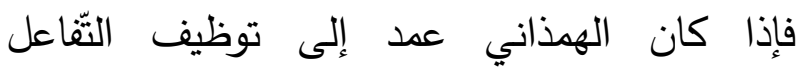
الاخلي، والاستدعاء الباطني بالاحتذاء بالمنهج

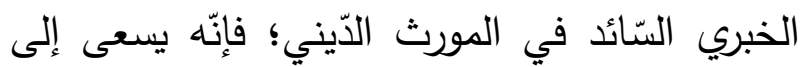
ضمان السّيطرة على المتلقّي، وإحكام القبضة عليه،

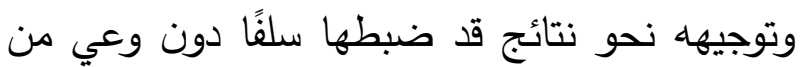

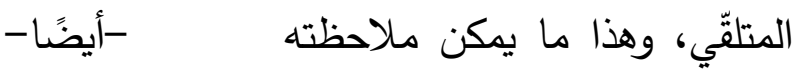

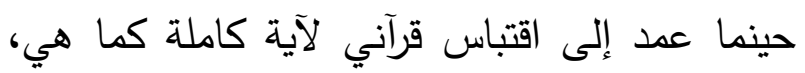
وقد أسبقها بالقول المتّصل بضمير المتكلم :"قُلْتُ:

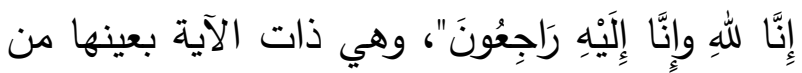

(r) ينظر : محمد نجيب العمامي، مقاربة النص السردي التخييلي من وجهة تداولية: "المقامة البغدادية" للهمذاني البية http://webcache.googleusercontent.com/search?q=cache :mdgdR3Bht4QJ:laamaminajib
العصر العباسي من انقسام في الواقع المعاش خاصّة في منتصف القرن الرابع الهجري، وبهذا يتّضح أنّ الصّورة التي تقدّمها المقامة للبطل المحتال، والثخصيّة السّاذجة تكاد تعرض أنموذجًا

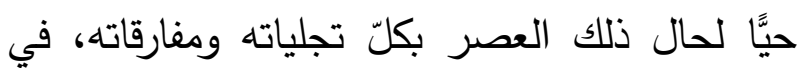
مقابل صورة واصفة للعالم المتخيل، وهذا ما يجعل بله من النّص منفتحًا على دلالات متعدّدة.

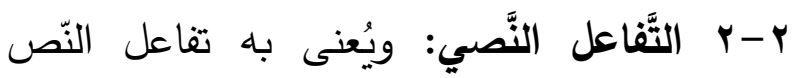
تناعلاً مباشرًا أو غير مباشر ، سواء كان داخليَّا فيما

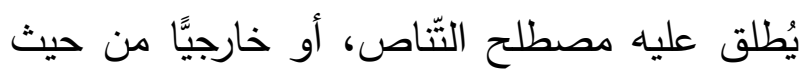
ارتباطه بتفاعل النّص مع القارئ ('). ووفقًا لذلك المفهوم؛ ينبغي الإشارة، إلى أنّ المقامة

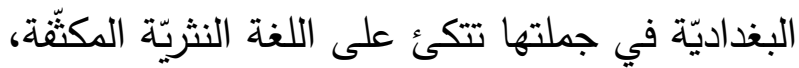

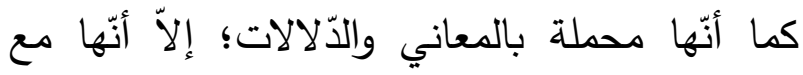
ذلك، تبقى مدعومة بشكلٍ لافتٍ بتنوّع أساليبها؛

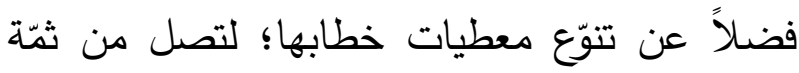
إلى وعي المتلقّي والتّأثير فيه، وبهذا تصبح المقامة نصَّا منفتحًا على فضاءات أوسع من التّاص.

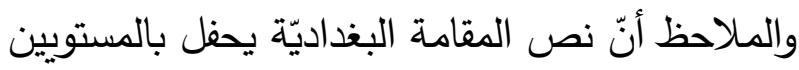

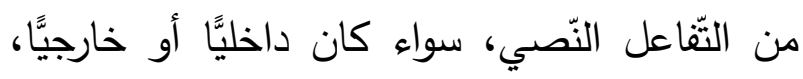
وهذا ما يمكن ملاحظته ابتداءً في مطلع المقامة:

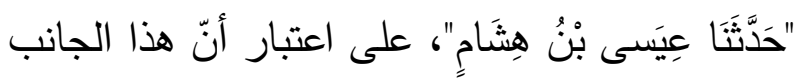
الإسنادي يشي ضمنًا إلى تداخل المقامة وتماهيها سرديًّا مع مجموعة من العلوم والفنون؛ كالحديث لتيثي النّبوي الثّريف، والخبر التّأريخي، والحكاية الشعبيّة. 
لغوي مختلف، فغيّب عنها بناءها الأوَل ليقدّمها للمتلقّي في قالب من السخريّة والتنّدر .

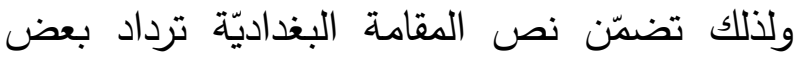

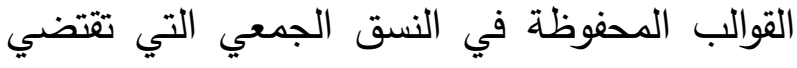
المعرفة المسبقة ما بين الدتخاطبين، عطفًا على الصى ضغط الامتثال للأعراف والتَّاليد الاجتماعيّة؛ كالتّمهيد للآعوة التي تفترض بدورها أسبابًا مقبولة،

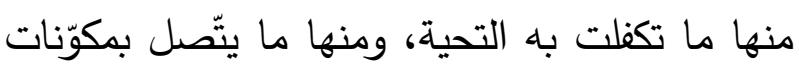

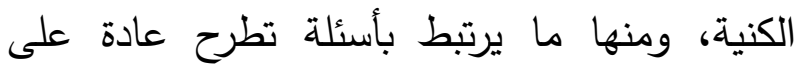
المعارف، ومنها ما يحدّده سياق الحديث والموقف، ئن

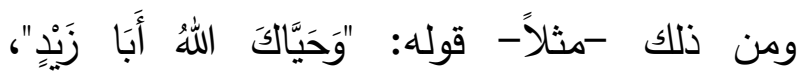

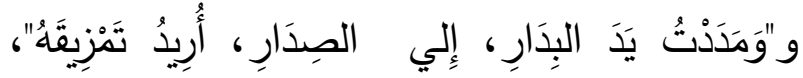

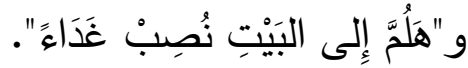

ولهذا؛ فالهذذاني سعى في نصّه إلى محاولة استدعاء حزمة من القوابل المتوارثة بالتّفاعل معها،

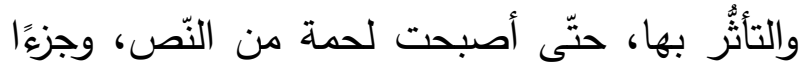
من تكوينه؛ بل تحوّل النَّ إلى حقول دلاليّة

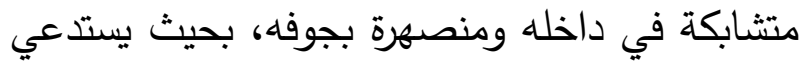

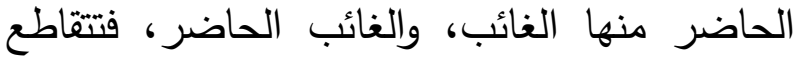
النّصوص في وعي المتلقي بناءً على ثثافته ووعيه الدعرفي، وهو ما يُنتِجِ نوعًا من التَّاعل والتَّواصل

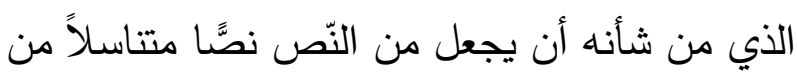
نصوص أخرى تختبر ثنافة المتلقي وموسوعته لمله الفراغات التي يستدعيها النّص. إنّ أهمية التّاص -أيًا كان نوعه ومصدره- تأتي من خلال انفتاح نص الدقامة على عوالم معرفيّة
سورة البقرة آية 104 ، ولأجل تحقيق غاياته عمد إلى توظيف تتاص آخر ؛ ولكنّه وظظّف بطريقة مختلفة من خلال استثمار بعض التّعبيرات القرآنيّة الموحية كما

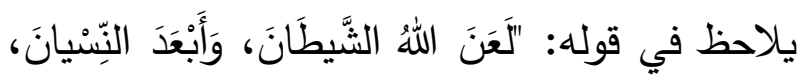

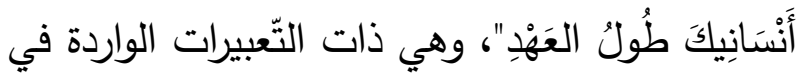
سورة الكهف آية זٓ.

فإذا كان الههذاني قد اعتمد على الاقتباس القرآني

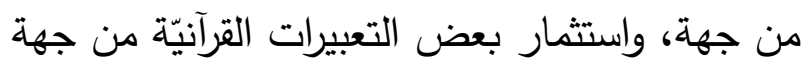
أخرى؛ فإنّه في الدقابل لا يغفل توظيف المثل

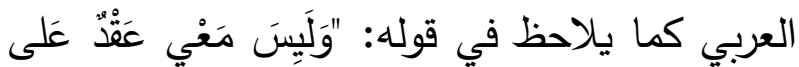
نَّْدِ"؛ كإِثارة موحية على أنّ من معه النقد يعقده في وعاء أو كيس، والفقير يُعدم ذلك كدالة على الفقر

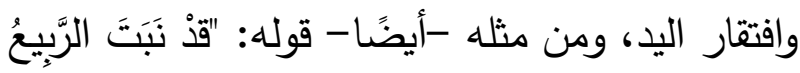

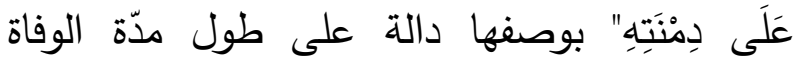
وتقادم زمنها، أو كما يلاحظ في خاتمة المقامة

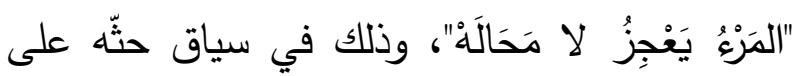
الحيلة من أجل كسب الرزق:

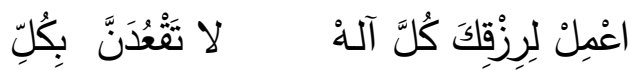
حَالَهُ

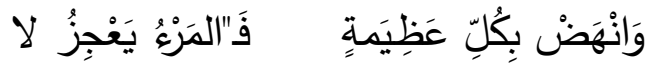
مَحَالَهُ"

والملاحظ أنّ المقامة البغداديّة تزخر بالتنّاص مع نصوص نثرية متعدَّة من جهة، ومختلفة المصادر من جهة ثانية، بعد أن أخضعها الهمذاني للغته الخاصّة، فأصبحت منزاحة عن بنية بنيتها اللغويّة الأساس بعد أن أعاد تكوينها وصياغتها في قالب 
r-r- البنية السسيونصيّة: تشكّل البنية السسيونصيّة كجزء من لُحمة النّص، ولذلك لا يكاد

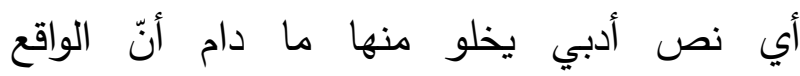
الاجتماعي يشكّل فيها بنية حيّة من بنى النّص.

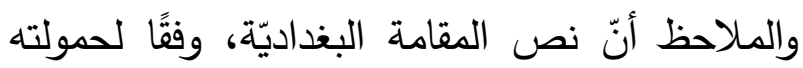

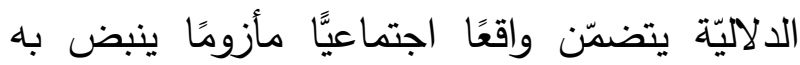
مجرى النّص وبنيته، وهذا ما يتّضح من خلال ثنائية

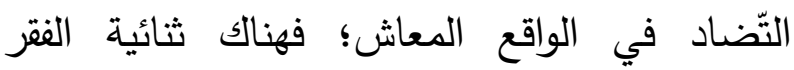
والغنى، والاحتيال والطّيبة، وحياة القرية والمدينة.

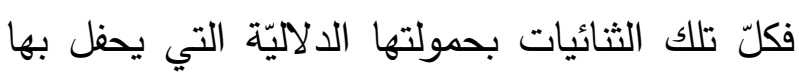
نص المقامة تقدّم وصفًا يكاد يكثف عن حالة الصّراع والانقسام في داخل البنية الاجتماعيّة، والتركيبة السياسيّة التي يعيشها إنسان القرن الرابع الهجري وتحديدًا منتصفه.

ولعلّ اللجوء لهذا النّوع من الكتابة جاء وفق معطيات

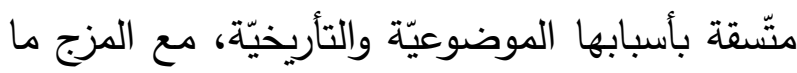
بين الواقع من جهة، والمتخيل من جهة ثانية، بهذا استطاعت المقامة الكثف عن عمق التجربة التي يحملها بديع الزمان الهمذاني، وفق حمولات تضمّنها النّص، وهو ما يوحي بالصور الواقعيّة التي قاربها

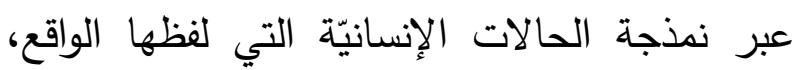
وأعاد إنتاجها في صورة أدبيّة. إنّ البنية النّصيّة تتطوي على ثنائية متضادّة ومتتاقضة في الآن ذاته، وذلك من خلال بؤرة متصارعة ما بين عالمين: عالم الثّراء والفقر ، وعالم

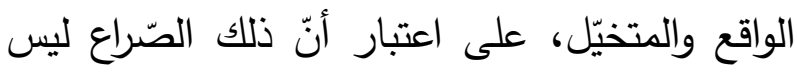

ومرجعيّة ثقافيّة، وذلك بتعدّدها وانشطارها، وتشابك

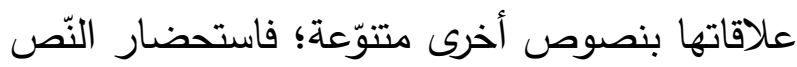

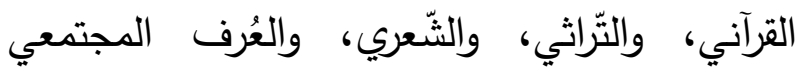
يفرض على المتلقّي أن يستدعى سياقًا حضاريًّا، وثقافيًا، واجتماعيًا لا يقف عند حدود العصر الذي لني نشأ فيه الهمذاني وأنثأ فيه مقامته؛ وإنّما يتجاوزهما لهاء إلى ما قبلهما من عصور مع ما فيها من حمولات

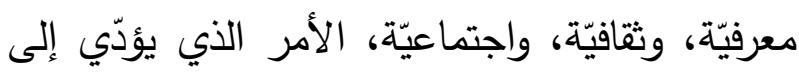
تحقيق أعلى درجة من فاعلية عمليّة التلقي

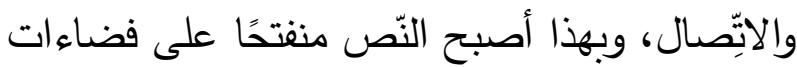

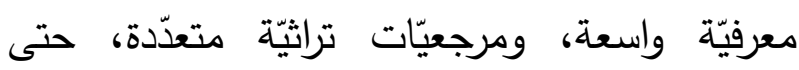
استحالت المقامة وفق هذا المنظور مشرعة على عرديات ترايه عوالم تتجاوز إطارها الزماني والمكاني؛ بل إنّها تتجاوز تجربة الهمذاني الذاتيّة، وهذا ما يؤكّدِ أنّ عمليّة الإبداع لا تتشأ من الفضاء، ولا تولد من فراغ،

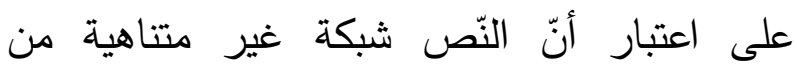

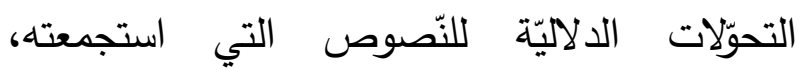
وتناصّت به، وتفاعلت معه.

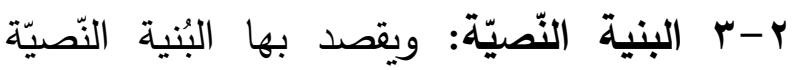
الصّتغرى والكبرى التي تشكّلت في النّص من خلال

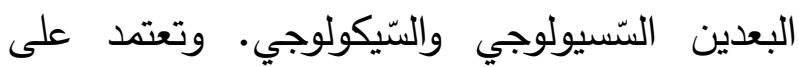
معايشة الكاتب للواقع معايشة اجتماعيّة ونفسيّة. وتتقسم إلى قسمين هما: البنية السيسونصيّة، والبنية السيكولونصيّة (')

(1) ينظر: مبروك، عبدالله، ضباب، نظرية الاتصال الأدبي بين التنظير

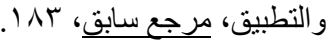




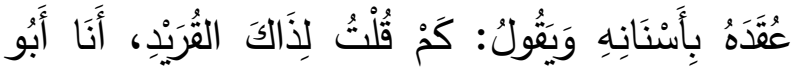

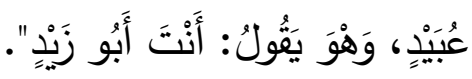

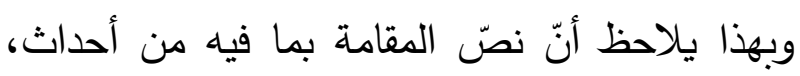

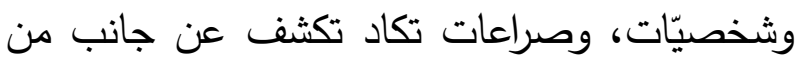
العيوب الاجتماعيّة، وتدلّ على خلل في البنّية

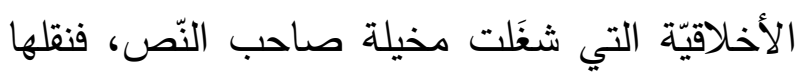
إلى المتلقّي دون أن يقحم نفسه في مجراها، فعكست

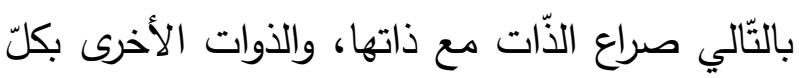

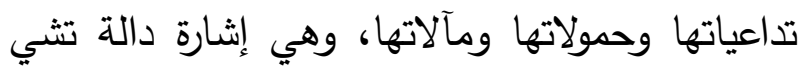

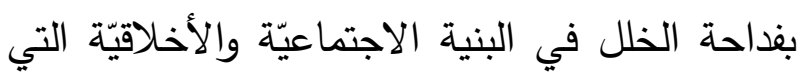
يعشيها إنسان منتصف القرن الرابع الهجري.

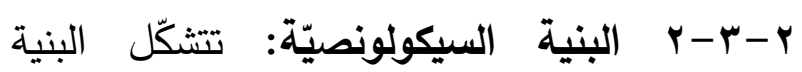
السيكولونصيّة في النّص من خلال العديد المواقف التي تحملها المقامة، على اعتبار أنّ الأحداث مبنية على التسلسل الزمني التقليدي لوقوعها من البداية، إلى الوسط، فالنّهاية، وهذه الطريقة شائعة في بناء الحدث في الموروث القصصي العربي، وترتبط البنية السيكولونصيّة بالبنية السسيونصيّة؛ لأنّ البنية السيكولوجيّة تتشكّل نتيجة للبنية الاجتماعيّة التي لاليه يدل عليها النّص('). والملاحظ أنّ الزّمان والمكان في المقامة البغداديّة جاءا مقترنين معًا من غير انفصال، باعتبارهما صنو الحياة التي يعيشها الإنسان، فشخصيّة سارد المقامة يتحدّث عن عالمه القصصي الذي لم يدعه لهـي معلقًا بأرض مجهولة، ولا بأزمان بعيدة؛ بل جعلهما
صراعًا بين محتال يُدعى عيسى بن هشام من جهة،

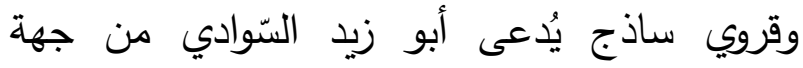
أخرى؛ بل هو صراع مثال في البنية المجتمعيّة القائمة، ولهذا فهو مرآة كاشفة عن واقع حياتي مأزوم

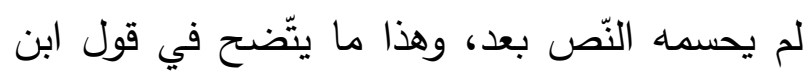

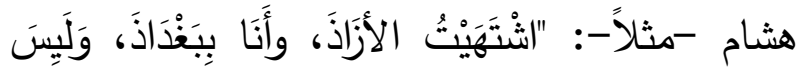

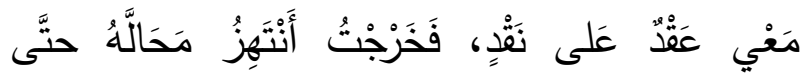

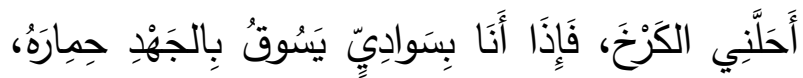

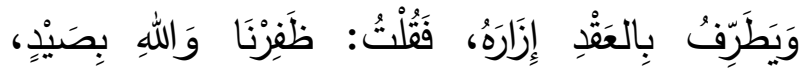

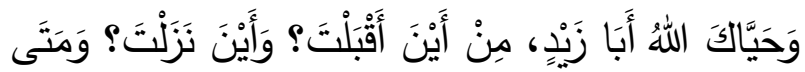

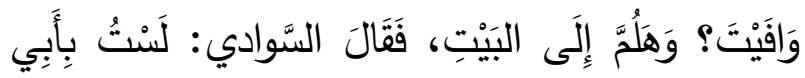

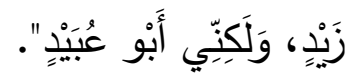
فالصّورة التي تقدّمها المقامة لشخصيّة السّوادي تكثف عن مدى قدرة ابن هشام في تخيُر ضحاياها، واصطيادهم، والتّغرير بهم، خاصّّة عندما عمد الهذذاني إلى تصوير ذلك بألفاظ موحية، وصور متلاحقة يشدّ لُحمتها الإيجاز في التّعبير ، والترّشاقة في التّصوير، مصحوبة بطرافة في رسم جُلّ لإئل التصصيلات المرتبطة بالحدث وتتابعه، يرافقها حواراتٍ موجزة، ولغة سلسة ومتصاعدة تكسر عنها رتابة السّرد أو توقفه، وتدفع به نحو موطن العقدة واحتدام

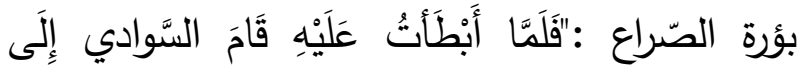

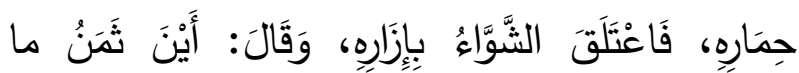

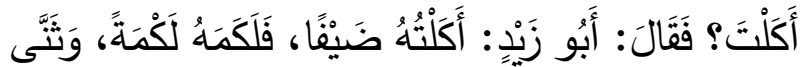

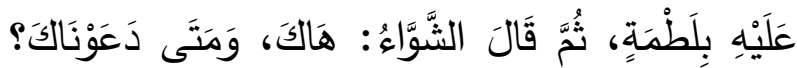

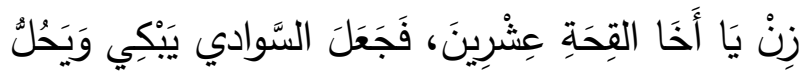


اللافت أنّ زمن المقامة الواقعي زمن قصير قد لا

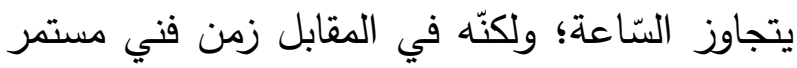

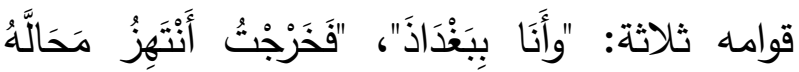

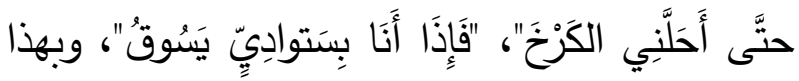

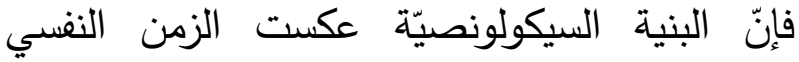
للشخصيّة، إلى جانب الزمن الواقعي، وذلك من النيك خلال الشعور بمرارة الواقع المعاش؛ نظير ما يحمله

من صراعات وتتاقضات طالت البنية الاجتماعيّة. والملاحظ أنّ اللغة الواصفة -التي احتواها النّص-

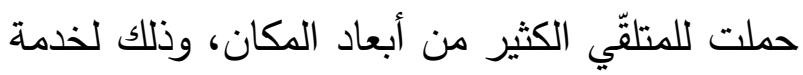

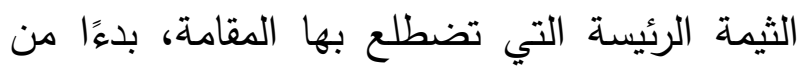

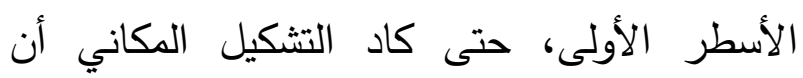
يتحوّل إلى صورة حيّة لدائرة أكبر للمكان، فمن قول الآل

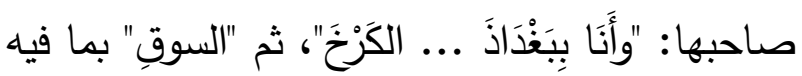

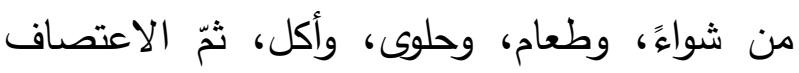

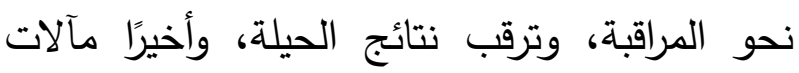

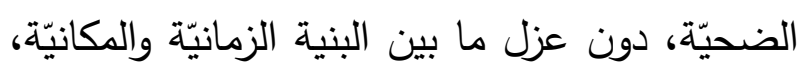

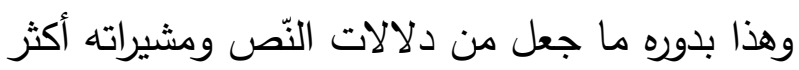

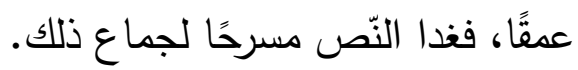
إنّ اللعبة السرديّة، والمقاطع الوصفيّة التي يزخر بهان التها

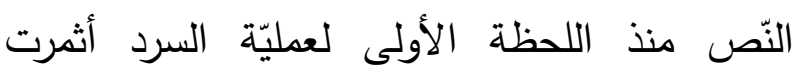
للمتلقّي خطابين غير منفصلين؛ أحدهما فنّي يتّصل باللغة الجماليّة التي قامت علينها المقامةتهات والآخر سردي يتعلّق بآليّات تقديم النّص؛ حتى استحالت لمات المقامة بنية نصيّة كبرى ذات دلالات وأبعاد موحية.

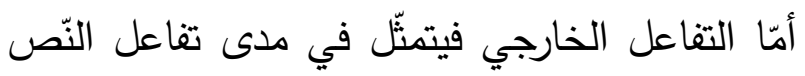

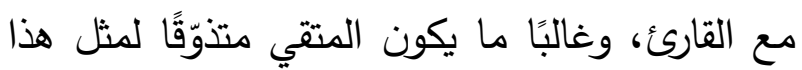

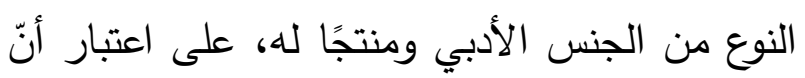

مرتبطين أيّما ترابط بشخصيته السرديّة والإسناديّة:

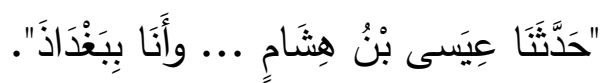

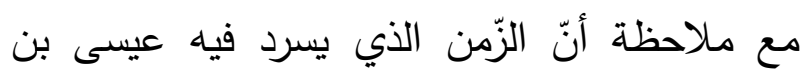

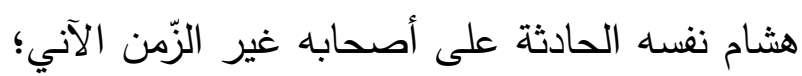
لأنّ الأحداث التي يسردها هي أحداث مسترجعة

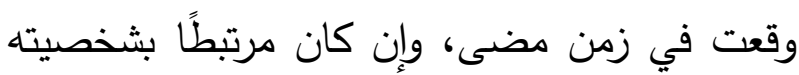

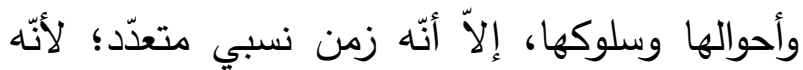

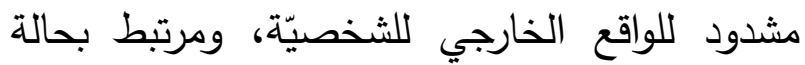
النفسيّة والثعوريّة، إنّه زمن متخلص من فكرة التأريخ بمفهومه الدّقيق للحدث النفسي أو الواقعي، ومرتبطُ

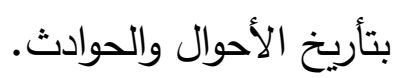

فالهمذاني نفسه عمد إلى الاشتغال على الثخصيّة التي لا تعبأ بالتدقيق في ساعات الزّمن، على اعتبار أنّ الزمن مأخوذ بقيمته من وقعه على بلى شخصيّة الإنسان، وارتباطه بمواقفه وبتجاربه وما تتركه من ان

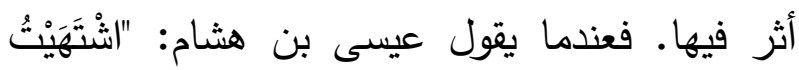

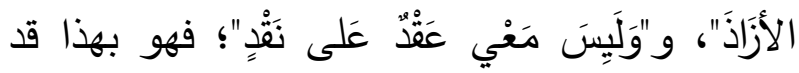

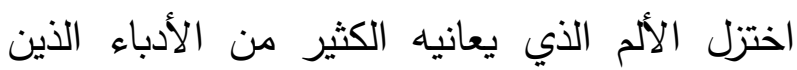
يحيون في ذلك العصر، وهو ما يكثف عن خلل متراكم في البنى الاجتماعيّة؛ بل هون هو لهيّة المعادل

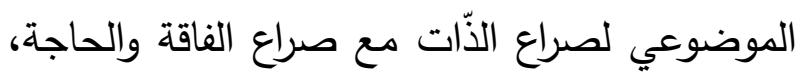
وكذا الحال عندما عمد إلى وصف حال السّوادي

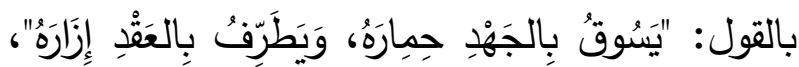
فهو بهذا التّبعير قد اختزل -أيضًا- واقعًا مرًا مكسوَّا بالفقر ، والفاقة، والحاجة برمزيّة ذلك السّوادي.

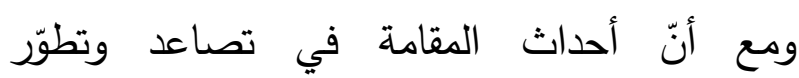
مستمرين، سواء على مستوى الزّمان والمكان جريًا نحو دفع الحدث الأخير إلى نهاية القصة؛ إلاّ أنّ الّيّا 
خصائصها التقنيّة التي تؤثِّر تأثيرًا معينًا في في النّص الذي ينتجه القارئ هو نتيجة تفاعله مع النّص المتلقيّي (') ذاته. والنّص المعني بالدراسة وصل إلينا مطبوعًا في ب- الوسيلة الاتِّاليّة كتاب ضمن مجموعة المقامات، تحت عنوان "مقامات بديع الزمان الهمذاني"، ويقع في صفحة من القطع المتوسّط، وحوى إحدى وخمسين مقامة، احتلت المقامة البغداديّة المرتبة الثالثة عشرة، بشرح مقتضب لبعض مفرداتها من قِبل العلامة

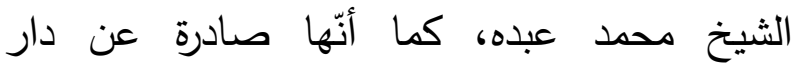
الفضيلة/ القاهرة، وقد خلا الكتاب من تأريخ النشر •

(1) ينظر: إيمانول فريس، قضايا أدبية عامة؛ آفاق جديدة في نظرية

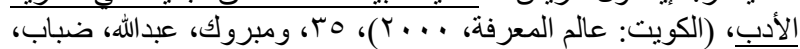

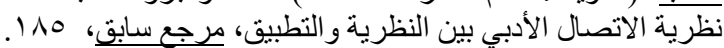

\begin{tabular}{|c|}
\hline 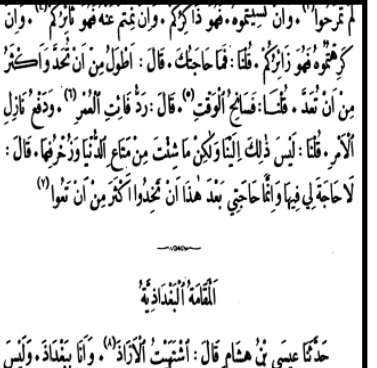 \\
\hline
\end{tabular}

\section{صورة ضوئية من الداخل}

رسم في أسفله تضمّن شكلاً تراثيَّا قديمًا يحمل بعدًا تقليديًا، تتوسّطه ريشة مائلة باللون الأخضر المتدرّج. في حين جاء عنوان الكتاب بصيغة ثنائية، أي يقوم على دالّين تجمع بينهما علاقة الإضافة، وذلك

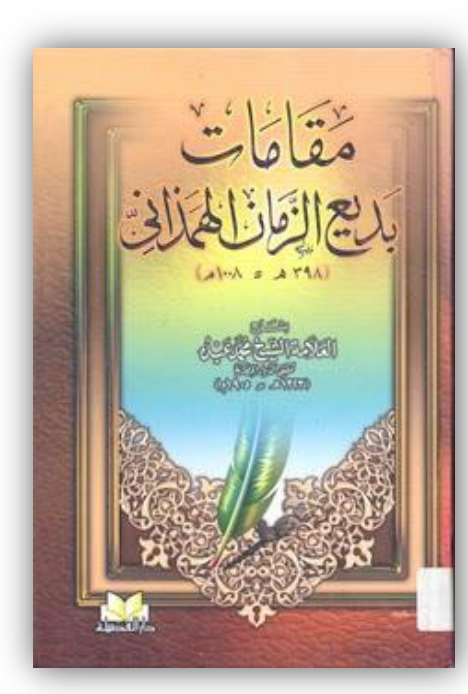

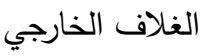

والماحظ أنّ عتبات الكتاب بدعًا من الغلاف قد افتقدت لعناصر الجذب، والإثارة، والإغراء، نظرًا لما ما يتطلّبه الغلاف عادة من خاصيتيّ التّاسب والثقافة البصريّة، حيث جاء في أكثر من لون، مع 
فكلّ نصّ يرد القارئ إلى وقائع ومفاهيم وقيم يكون

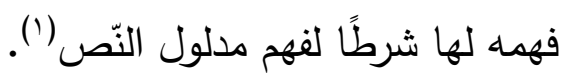
وبناءً على ذلك؛ ويمكن أن تتمّ معالجة هذا المحور

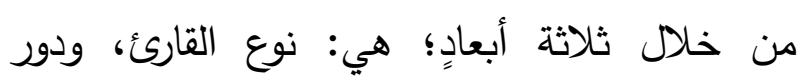
القارئ، وإستراتيجيّة الآِّصال. ع - ا نوع القارئ

ويقصد به متلقّي النّص الأدبي، سواء كان قارئًا مقصودًا أو ضننيَّا، وفي أغلب النّصوص الأدبيّة

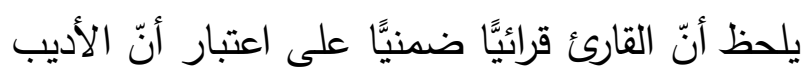
لا يتوجّه بنصّه إلى قارئ محدّد؛ ولكنّه يتوجّه إلى الى الى

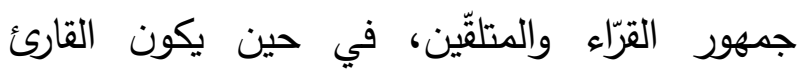
القصدي هو ذاك القارئ الذي يقصده الأديب بعينه، ويوجّه إليه نصّّه.

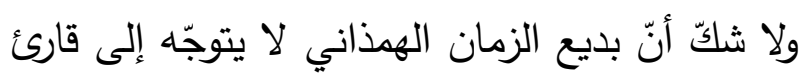

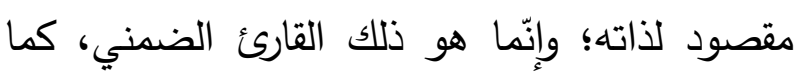

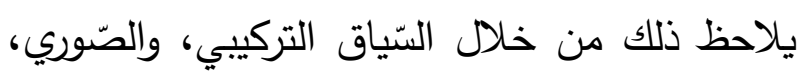
والدّلالي. وبهذا؛ فإنّ القارئ في هذه الحالة يعتبر

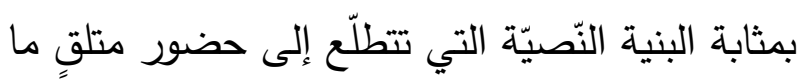
دون أن تحدّده بالضّرورة، فهو الذي يقوم بعمليّة

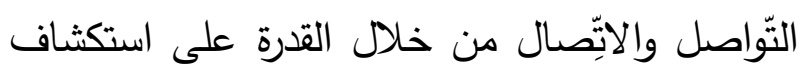
الثّفرة الكامنة في النّص، التي هي بمثابة المعنى غير المألوف من المألوف؛ لأنّ المعنى المألوف في لأني

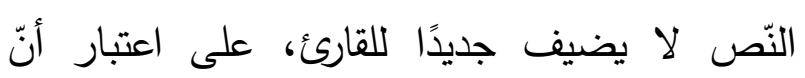

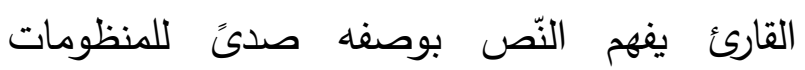

(1) ينظر : مبروك، عبدالله، ضباب، نظرية الاتصال الأدبي بين التنظير

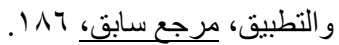

بإضافة مقامات إلى بديع الزمان الههذاني، وكأنّ المضاف والدضاف إليه بمنزلة الثّيء الواحد. وفي منتصف الغلاف، وبسمك خط أصغر ، وردت الصناف

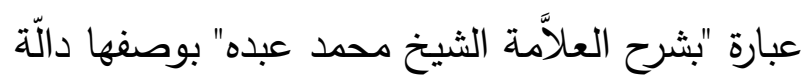

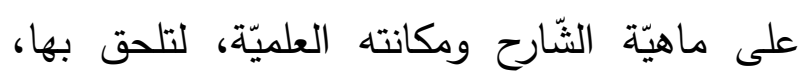
وبخطٍ أقل سمكّا "فتى الديار الدصرية"، كأنّما هي إيحاء بالتوجَه الأيديولوجي للشّارح. أمتا عناوين المقامات -ومنها الدقامة البغاديّة- فقدائد جاءت متساوية تمامًا مع سمك خط المتن، ما أفقدها خصوصيّة العنوان، ودوره الذي يلعبه طبقًا لتحوّلات

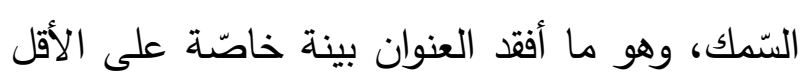

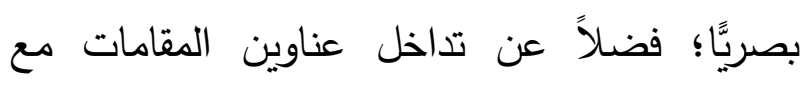
بعضها البعض داخل الصَّحات، فلا يعرف انتهاء

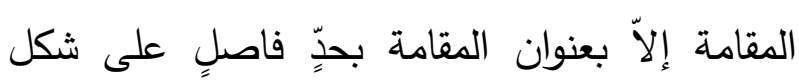
هندسي بسمك صغير جذًا.

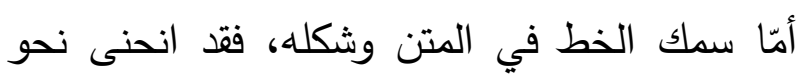
التوسط متِذًا الضّبط سمة لازمة في كلَ الكتاب،

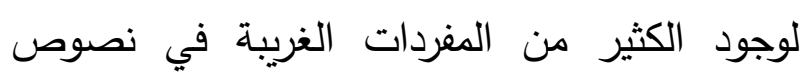

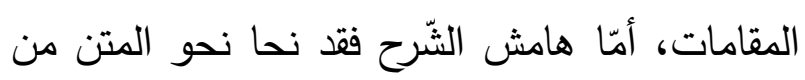

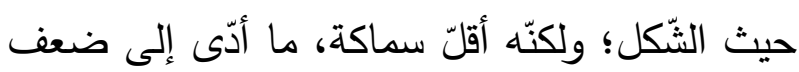
الإفادة منه.

\section{ع - المتلقّي وإستراتيجيّة القراءة}

ويقصد به بالمتلقّي القارئ للنّص سواءً أكان قصديًا أم ضمنيًا؛ ولهذا ويفترض الآتصّال الأدبي أن يكون

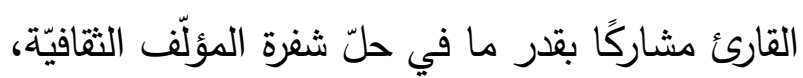


ع-r دور القارئ

إذا كان متلقيّي النّص هو المسؤول الأوّل عن فلكّ شفرته وفتح مغاليقه؛ فإنّ له كذلك العديد من الأدوار المتكاملة؛ لتتمّ بها "الرؤية الموضوعية والثمولية للنص من حيث معالجة أبعاده ومستوياته"('). ومن أهم تلك الأدوار التي ينبني أن يتمثّلها قارئ النّص وفقًا لنظرية الآِّصال الأدبي؛ هي:

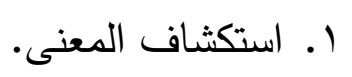$$
\text { r. - مله الفراغات. }
$$

r. ربط الأجزاء غير المترابطة. ع. ضبط البنى المتحوّلة. 0. تأسيس البُنية النهائيّة.

\section{צ- - 1 - استكشاف المعنى}

أي كثف القارئ للمعاني الإيحائيّة والمتعدّدة في النّص، والتي تتكشف من تتوّع ثقافة المتلقّي، ووعيه المعرفي، وتعدّد قراءاته، ولعلّ استكشاف المعنى يتمّ

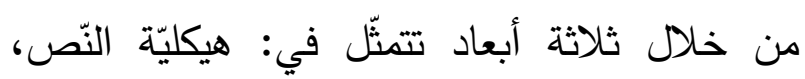
والصورة العقليّة، والبنية الإبلاغيّة(r). أمّا هيكليّة النّص فينبغي من خلالها النّظر إلى النّص على أنّه هيكل عظمي، أو جوانب تخطيطيّة يقوم القارئ بتحقيقها وتجسيدها، أي أنّ القارئ في هذه الحالة يستمدّ وجوده وكينونته من أنّ العمل الأدبي ليس نمَّا تمامًا، وليس ذاتيّة القارئ تمامًا؛ ولكنّه يشملها مجتمعين، أو مندمجين.
الفكريّة، والمعرفيّة، والاجتماعيّة، والسياسيّة التي اختارها وجسّدها في رصيده الخاص. إنّ المقامة البغداديّة لا تتوجّه إلى قارئ محدّد بعينه،

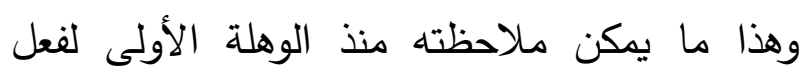
الخطاب؛ بدءًا من عنوان المقامة ذاته، مرورًا بخطاب التّصدير : "حَدَّتًَا عِيَسى بْنُ هِشَّامِ"، وانتهاءً بالبيت الشعري:

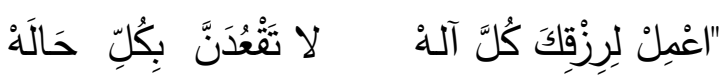
وَانْهَضْ بِكُلِّ عَظِيَمِةٍ

\section{فَالمَرُْْ يَعْجْزُ لا مَحَالَهْه}

ولذلك؛ فإنّ خطاب المقامة لا يتوجّه إلى فئة معيّنة من القرّاء أو لقارئ بعينه؛ ولكنّه موجّه لكلّ متلقّ للأدب في المقام الأوّل، ولكلّ محايث لمثل ذلك الواقع المأزوم في كلّ زمان ومكان؛ نظرًا لما يحمله النّص من سمات فنيّة وجماليّةة، وما يعكسه من جوانب إنسانيّة، واجتماعيّة، وسلوكيّة. والملاحظ أنّ الهمذاني لم يقتصر على الخطاب النثري؛ ولكنّه عمد إلى تضمين نصّه بخطاب شعري على لسان عيسى بن هشام، بطلب أعمال مباشرة جاءت بصيغتي الأمر والنهي: "أَعْمِلْ"، و "لا تَقْعَدَنَّ"، يقابلها عمل غير مباشر ظاهره التّرير، وباطنه الإشادة بالتحيّل والتّحايل والكذية، مدغومًا بصيغة التهنئة بالنّصر التي لا يقصرها لنفسه فحسب، وهي صيغ خطابيّة لا تقف عند حدودها الزمانيّة والمكانيّة ما دام هناك صراعان طبقي واجتماعي، وواقع

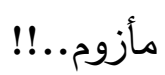


انغماس طبقة واحدة متفرّدة بالمثال، والعيش الرغيد بألوان الطعام، وأنواع المأكولات. أمّا البنية الإبلاغيّة للنّص بوصفها مرحلة من مراحل استكثاف المعنى، فلا يمكن أن تتحقق إلاّ من خلال

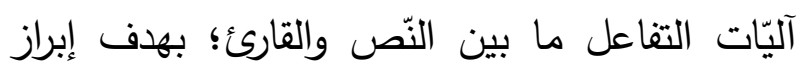

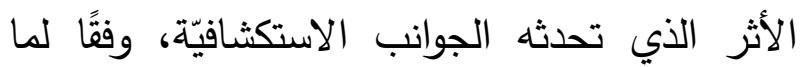
يختزله النّص من دلالة عميقة يشي إليها.

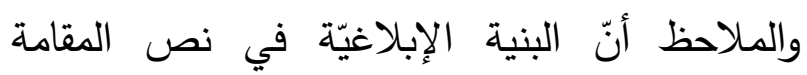

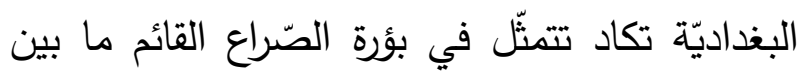
مواهب الأديب، وفطنته، وذكائه، وسلطة أثخنت

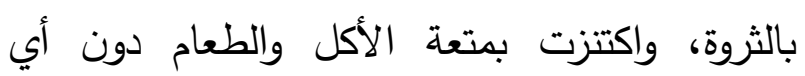

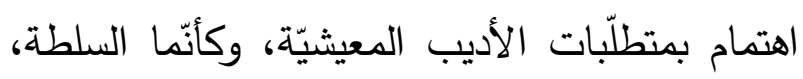
وكذا المجتمع أصبحا خصمين لمواهب الأديب الهيب

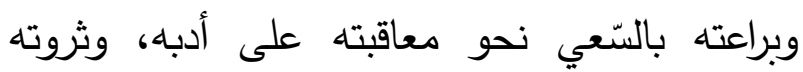

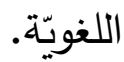

وهذه البنية لا تُلاحظ عادةً إلاّ في من خلال المستوى الدلالي العميق للنّص، ولذلك فلا نكاد فئل فناد نتبينها في العناصر اللغويّة الواحدة، أو التّراكيب

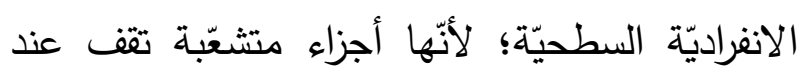
حدود الإثباع والإمتاع؛ ولكنّها في المحصلة النّائية تتنمي إلى ذلك الجذر الدّلالي العميق، وتعود إليه،

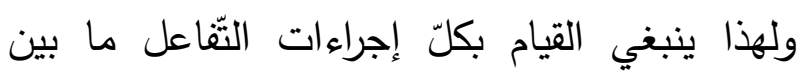
عناصر النّص التي يفيض بها من أساليب لغويّة

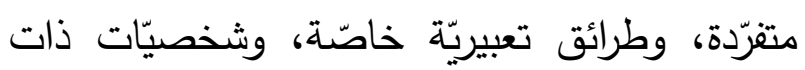
ملامح مختلفة، وسلوكيّات استثنائيّة، وأحداث متفرّدة وفئية

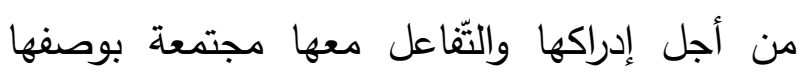

ومن ثٌّ؛ فإنّ النّظر إلى النّص الأدبي بعيدًا عن دور

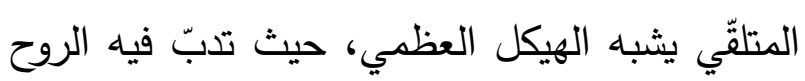
حينما يشرع المتلقّي في فض مغاليقة، وفك شفرته، وإعادة إنتاجه، وتركيبه. والملاحظ أنّ نصّ المقامة البغداديّة في حال استبعاد أي إسقاطات للمتلقي تتعلق بفهم دلالاته ومشيراته،

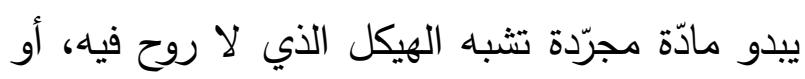

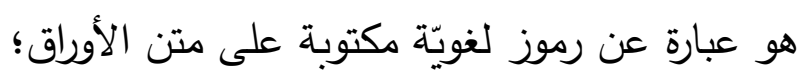

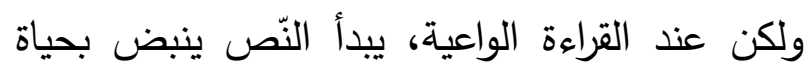
المعاني، ويستجيش بالدلالات، لتأتي المرحلة الثانية من مراحل استكشاف المعنى المرتبطة بالصورة العقليّة التي تتشكّل أثناء فعل القراءة لبناء الموضوع بناءً جماليَّا ودلاليَّا في صورة حيّة ملؤها التّاغم لتاه والتّلاحم. إنّ نصّ المقامة محمّل برسالة ذات مغزى إنسانيّ وثيق الصّلة بحياة البشر في جميع العصور؛ نظرًا لوجود الكثير من الثوابت المتعلّقة بحاجات الإنسان

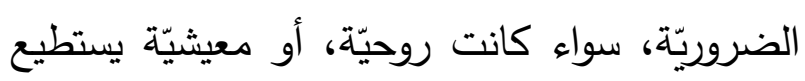
المتلقّي كثفها من خلال معايشته لحياة النّص. فغياب العدالة الاجتماعيّة، واستغراد طبقة محدّدة بالثّروة أورث المجتمع سلسلة من الفقراء والمعدمين، كما أورثه ضياع الكثير من أصحاب المواهب الأدبيّة، وهو ما أدّى بهم إلى اصطن اصناع الحيلة

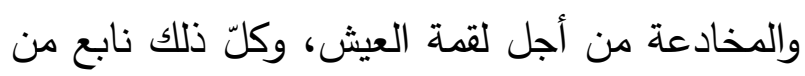

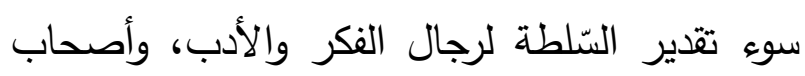
المواهب، فغاب الرقيب، وتلاشى الحساب من خلال 
في منتصفه؛ يقابلها شخصية السّوادي الترّمزة إلى ولى القيم النبيلة، وما يتعلّق بها من طيبة النّّس، وسلامة القلب، خاصّة بعد أن أصبحت الكديّة والاحتيال أداة

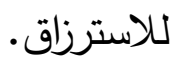

فالقراءة الواعية من قِبل المتلقّي تكشف عن البنية الدالة، على اعتبار أنّ النص الإيحائي كثيرًا ما لئاعل

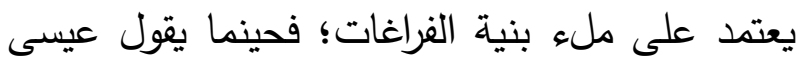

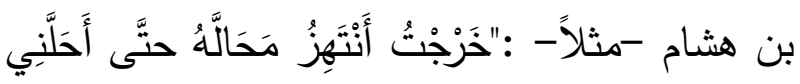

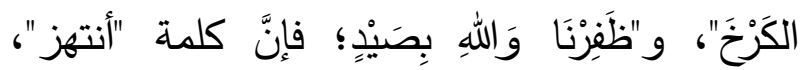
و"ظفرنا.. وصيد"، توحي بدلالتين، الأولى ترتبط بطريقة ما إلى الشّروع في الحيلة، أمّا الثانية فتتعلّق

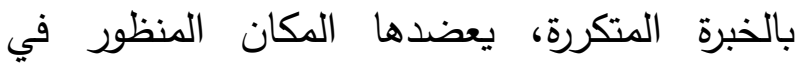
"الكرخ" بوصفه أرقى أحياء بغداد، الذي لا يؤمَّه إلاًّ

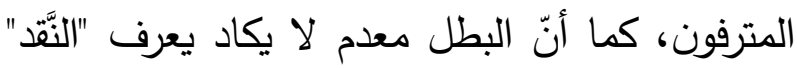

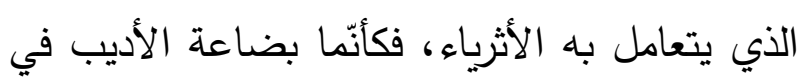

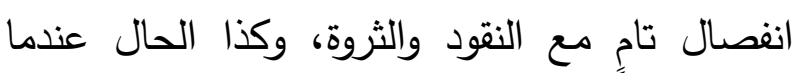

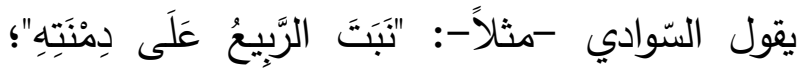
فإنّ دلالة المثل لن تستقيم إلاّ من خلال الترانه

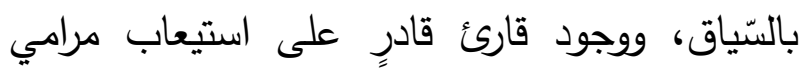
المثل والمغزى من توظيفه في جوف النيان النص، وارتباطه بموقف الثخصيّة، وبهذا يسهم القارئ

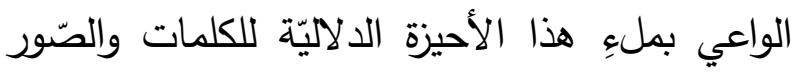
والمعاني في النّص.

\section{ع-r-r ربط الأجزاء غير المترابطة}

في هذا الجانب يقوم القارئ بربط المعاني الداليّة والثعوريّة فيما بينها، فقد يكون النّص غير مترابط بلتيط
أدوات لا تتكرّر - غالبًا - بهذه الكيفيَّة إلآ في نصِّ

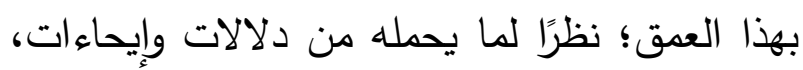
سواء كانت ظاهرة أو مضمرة. צ-r-r

إنّ على القارئ دورًا كبيرًا للوعي بدلالات النّص وفهم التهات مشيراته، ولن يتمكّن من القيام بذلك الدور إلآ من خلال ملء الفراغات التي يحدثها النّص، وذلك وفنًا لللبنية الكليّة المتمثّة فيما لم يقله النّص تصريحًا؛ ولكن السَّاق النّصي عبّر عنه تعبيرًا ضمنيًًا (1). والملاحظ أنّ نصّ المقامة البغداديّة لا يصرّح بماهيّة

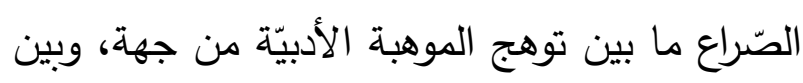
سلبيّة السلطة والواقع الاجتماعي من جهة ثنانية، ورتّما أنّ استعمال التقتية السترديّة "حَدَّنا" ضروريّة في هذا الدقام؛ للكثف عن ماهيّة هذا الصَّراع دون الاستعداء للسلطة القائمة، والهجتمع المثال، ولهذا فما من كلمة، أو تركيب، أو صورة، أو حوار، أو أو الو الوال إشارة لمّاحة مضمَنة في بنية النّص إلاّ كان لها

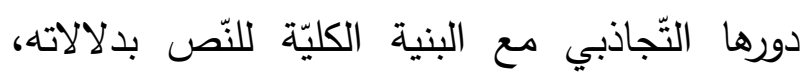

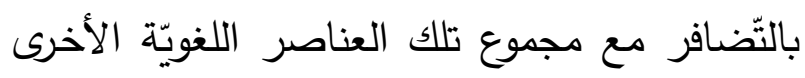

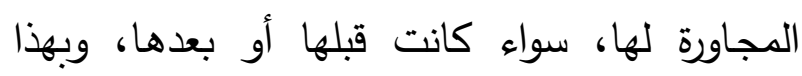
تكون بنية الصّراع ما بين الأديب عيسى بن هشام، وبين موازين القوى في مجتمعه العباسي، وكلَّها مجتمعة تفنّر لنا دالة النّص، والغرض منهـ. فثخصيّة عيسى بن هشام ترمز إلى انقلاب القيم وتدهورها في مجتمع القرن الرابع الهجري، وخاصَّة (1) (بنظر: المرجع السابق، 191. 
المعنى اللغوي للبنية معبّرًا عن الدلالة المعجميّة؛ ولكنّه في سياق النّص يُعبِّر عن الدلالة الإيحائيّة والرمزيّة (r).

والملاحظ أنّ نصّ المقامة البغداديّة يحفل بالعديد من الثّواهد على تحوّل المعنى المعجمي إلى بنية دلاليّة منظورة في السّياق التي ترد به، بحيث تكتسي معنى

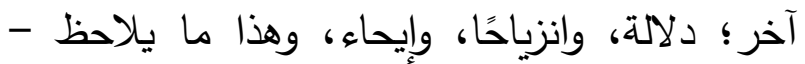

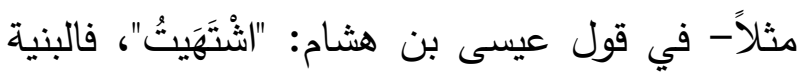

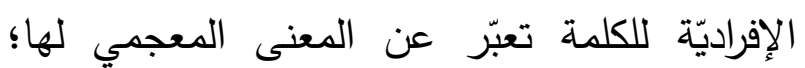

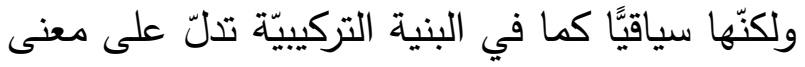
الجوع، والرّغبة الملحّة للأكل، كما قد تشي إلى قلّة ذات اليد التي وصل إليها حال الأدباء والعلماء في

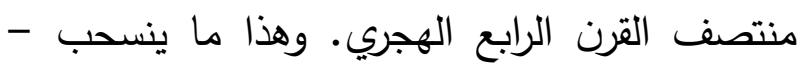

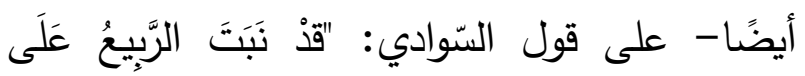
دِنْنَتِه" على اعتبار أنّ كلّ كلمة مفردة لها معناها الخاص بها كبنية إفراديّة تتّصل بمعناها المعجمي

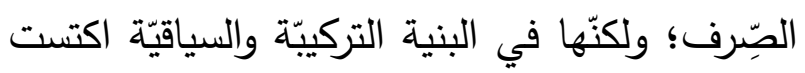

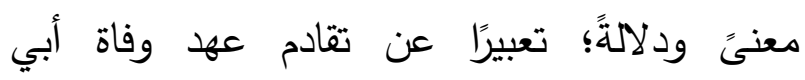

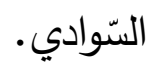

\section{ع - ץ-ه تأسيس البنية النهائيّة}

تتأسّس البنية النهائيّة للنّص من خلال الفراغات البنائيّة التي يتمّ ملؤها والأجزاء الترّكيبيَّة التي تحّة ربطها، والبنى المتحوّلة التي تمّ ضبطها، وكلّها تسهح

في تشكيل البنية النهائيّة للنّص(َ).

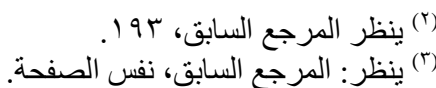

على مستوى التركيب اللغوي المألوف؛ كترتيب الأفعال، والأسماء، والحروف، وذلك وفقًا لسياقاتها المألوفة في التراكيب الإسناديّة، سواء كانت اسميّة والتي وفعليّة؛ لكنّه قد يكون مترابطًا على المستوى الفني

والثعوري (') وبناءً على ذلك؛ يمكن القول: إنّ المقامة البغداديّة

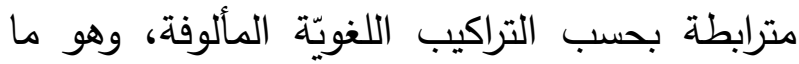
يجعل من البعد الدلالي، وكذا الفّي والثّعوري مترابطين بحسب السّياق الذي قيلت فيه، وذلك ولك بالنّظر إلى مدى قدرة المتلقّي على التّفاعل مع النّص ووعيه به، ومن ذلك على سبيل التمثيل قول

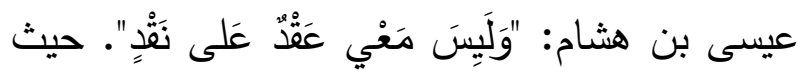
يلاحظ في المثل السابق أنّ هناك ترابطًا تركيبيَّا بالمعنى المألوف لهذا التركيب؛ ولكن في المقابل غير مترابط دلاليًّا إلاّ من خلال وعي المتلقّي بأبعاد المثل، وفهم المغزى الدّلالي من توظيفه، والمّياق

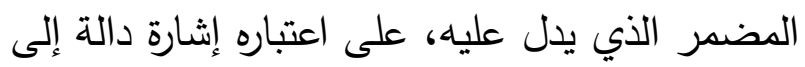
قلّة ذات اليد من ناحية، وإضمار الحيلة والكديّة سياقيَّا من ناحية أخرى، ومثله مثل الوصف المتعلّق

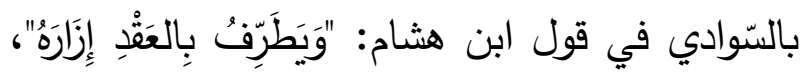

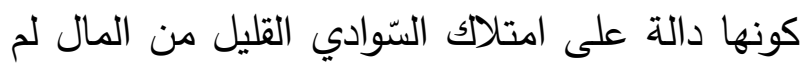
يصبه إلاّ بالكثير من الجهد والعناء. ع - r - ـ ضبط البنى المتحوِّلة يقوم القارئ في النَّص -أيضًا - بضبط البنى اللغويَّة والسياقيّة التي تتحوّل عن دلالاتها النّصيّة، فقد يكون ليّن 
ع-ب-1 البعد الذّاتي: يعدّ أحد الأبعاد الرئيسة في إستراتيجيّة القراءة، من خلال "تعميق الوعي الذاتي لتصدي من خلال انفصال الذات عن ذاتها أثناء عملية

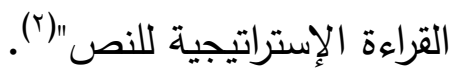

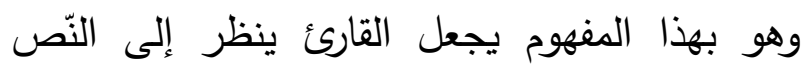
بمعزلٍ عن ذوات الآخرين، أو عن أي مؤثِّرات أخرى؛ بل ينبغي عليه عزل تجاربه الخاصّة وتتحيتها جانبًا، بحيث يتعامل مع النّص تعاملاً حياديًّا بعيدًا عن أي تجربة ذاتيّة أو غيريّة(؟).

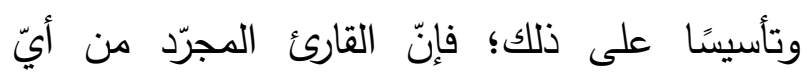
مؤثرّات، أو تجارب أخرى، يرى أنّ المقامة البغداديّة

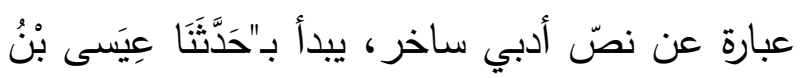

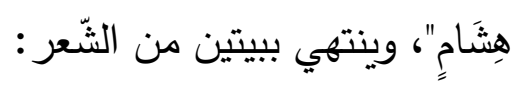

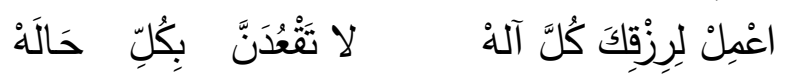

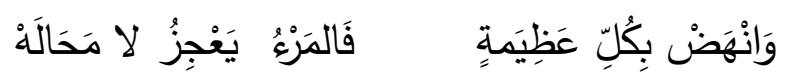
وما بين البداية والنهاية تتشكّل مجموعة من الأحداث

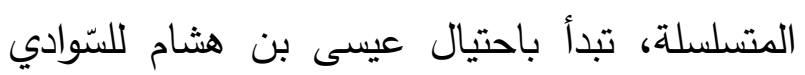

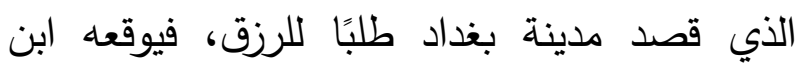

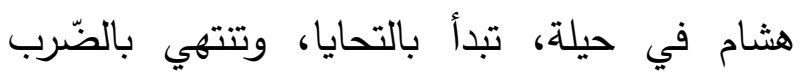

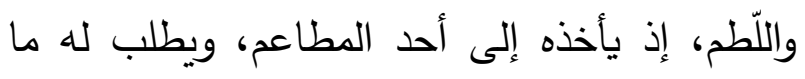

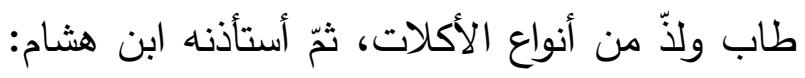

(r) (المرجع السابق، نفس الصفحة.

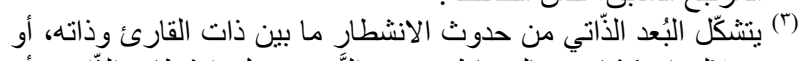

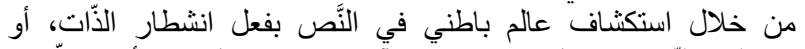

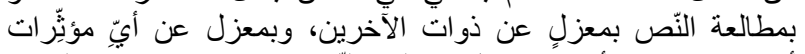

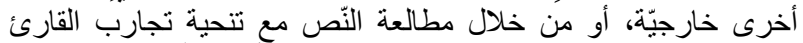

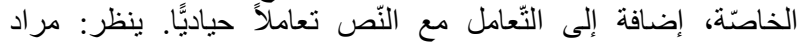

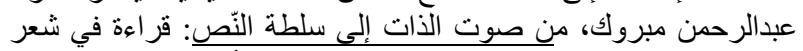

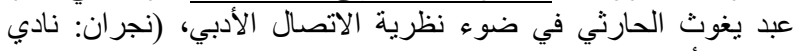

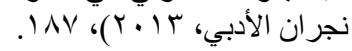

وتأسيسًا على ذلك يمكن ملاحظة أنّ البنية النهائيّة للنّص تتمحور حول: ا ـ غياب العدالة المجتمعيّة في ظلّ ضعف ضلف مركز

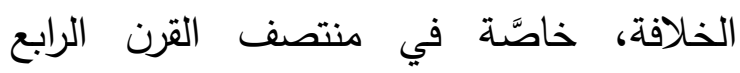
الهجري تحديدًا، وهو ما أدّى إلى وجود طبقتين فئن

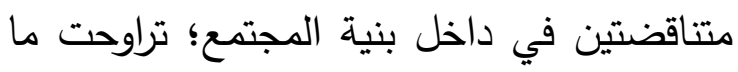

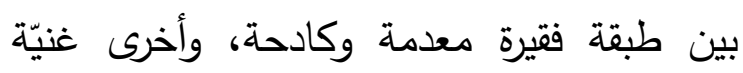
تانتعم بفاحش الثّراء.

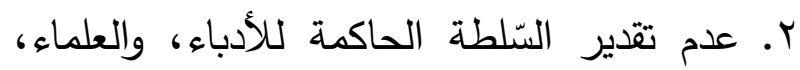
والثّعراء، وأصحاب المواهب، حتى وصل بهم الحال إلى اتِّخاذ الكدية والحيلة سبيلاً للمخاتلة واهلة من أجل لقمة العيش. r. تدهور في القيم، وانفلات في الأخلاق، وانعدام التكافل والتّعاون ما بين أفراد المجتمع؛ فضلاًا عن الأنانية الفرديّة، والإحساس بالغربة الذانية الذاتيّة والمجتميّّة، فأصبح الفرد في عصر التئه الكاتب ضحية للظّروف الاجتماعيّة والسياسيّة. ـ. اتّّم النّصف الثاني من القرن الرابع الهجري بتناقضات حادّة، أنتجت تفاونًا واضحًا واختلالاً اجتماعيًّا تجلّى في العوز والحاجة، وقلّة ذات وات اليد؛ حتى طال الكتّاب والأدباء.

؟ - ب إستراتيجيّة القراءة

ويقصد بها "الآلية التي يتم من خلالها قراءة

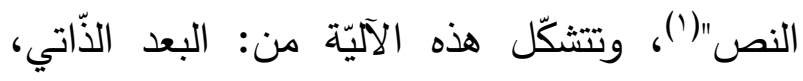
والصّوري، والباطني، والجدلي، والوظيفي. 
عناصرها الجماليّة، والفنيّة، واللغويّة، والسرديّة، وفق

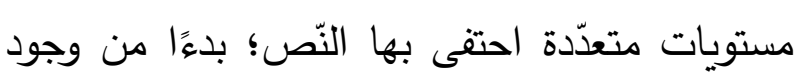

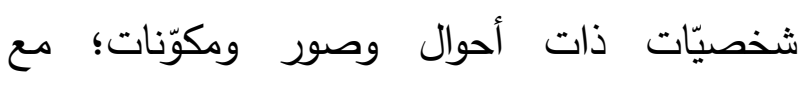
اختلاف في مواقفها واتِجاهاتها وردّات أفعالها، إضافة إلى تعارض مصالحها وتباين غاياتها، مع ما فا فواتيات

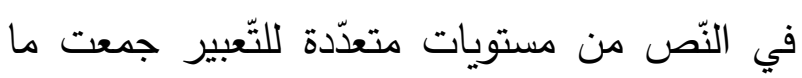
بين السرديّة، والوصفيّة، والحواريّة، والجدليّة، وبهذا يمكن ملاحظة أنّ الصورة تتجاوز نطاق الخيال البسيط الذي يقف عند حدود السخرية والتّلية والإضحاك.

ولا شكّ أنّ هذا المستوى من القراءة يعدّ مثمرًا، سواء

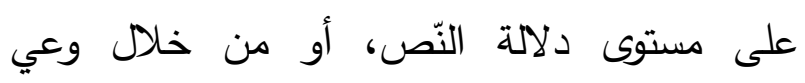
المتلقّي؛ لأنّ الاتّجاه إلى صنى صنع حياة متحرّكة،

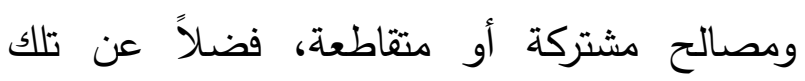
الأهواء المتضاربة غير المتجانسة تحتاج إلى طاقة

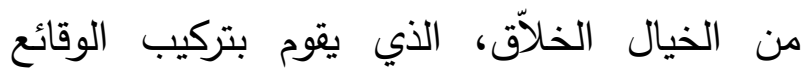

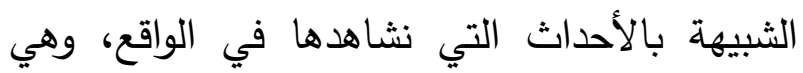
شعواء، عزلاء، متفرّقة، مبعثرة، غير جذابة؛ ولكنّها

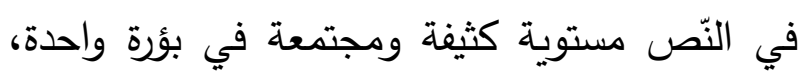

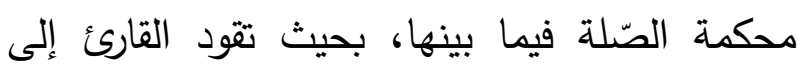

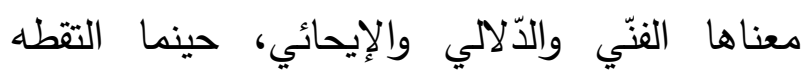

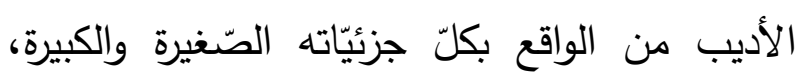

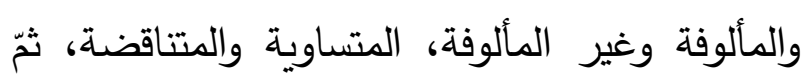

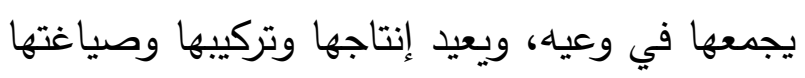
هن مخزون وعيه المعرفي، وثقافته، وخبراته، فإذا هي في النّص ذات حياة نابضة، ووجود متميّز .

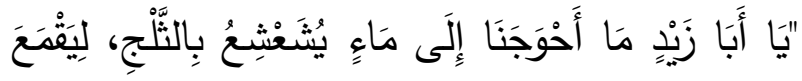

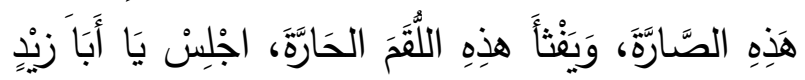

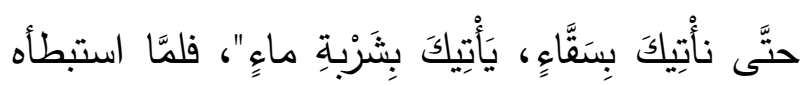
السَّوادي قام إلى حماره منصرفًا، فبادره الثَّوَّاء : "أَيْنَ

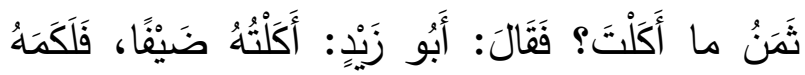

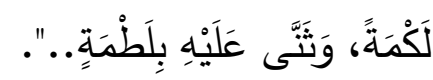
فإذا كانت المقامة قدّمت للقارئ صورة من صور الحيل والكدية، في قالب ساخرٍ مضحك؛ فإنّ مثل

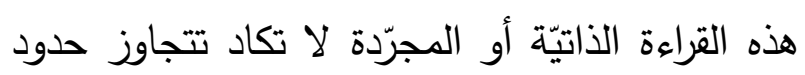

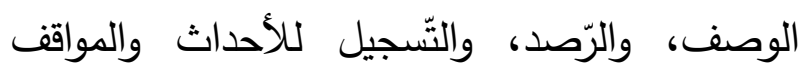
والثخصيّات دون أن يُضفي عليها القارئ أيّة أبعادٍ، والئ

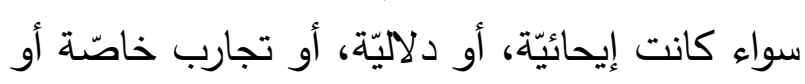
عامّة، إلاّ في حدود وعيه المعرفي، وخلفيته الثقافيّة،

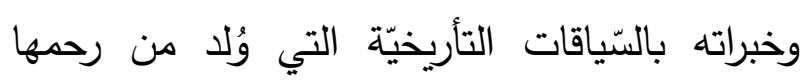
النّص، وهذا ما يمكن تسميته بالمستوى الأوّل للقراءة. ع - ب-r البعد الصُّوري يأتي هذا البعد في المرتبة الثانية من مراتب القراءة الإستراتيجيّة للنّص بعد البعد الذاتي؛ لأنّه يتشكّل

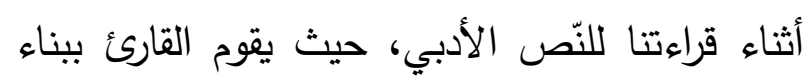
صورة التّركيب السّلبي، وهو التصوّر الذي يتشكّل في الوعي أثناء القراءة، وهو ركن أساس في الخيال الإبداعي الذي ينتج في النهاية الموضوع الجمالي. والملاحظ في المقامة البغداديّة أنّ هناك انسيابًا

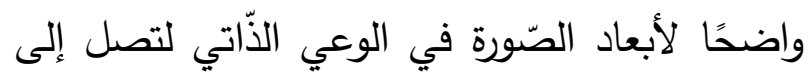

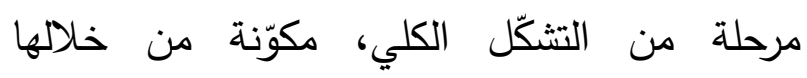


الحدث: "فَفَرْجْتُ أَنْتَهِزْ مَحَالَّهُ"؛ يوحي بسعي هذا

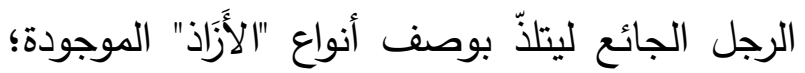

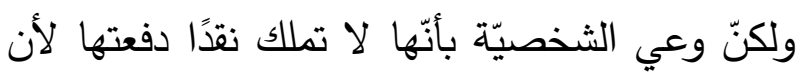

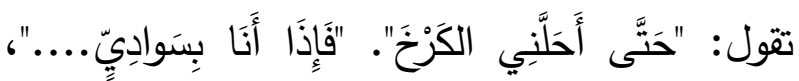

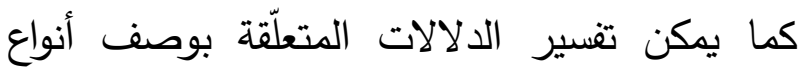

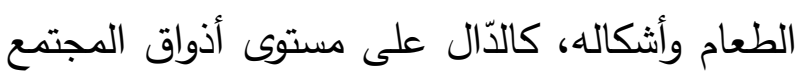

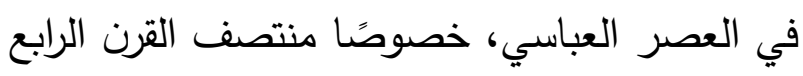

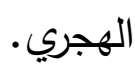

\section{ع - - ب-r البُعد الباطني}

أي "استكثاف بنية النص الباطنية من خلال فهم القارئ للنص"(')، وهذا البعد الإستراتيجي يشكّل

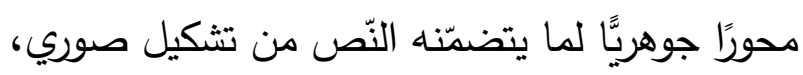
وسياقي، ودلالي. - ولي. فإذا كان نص المقامة يبدأ بجملة "حدّثنا عيسى بن ودلا بن

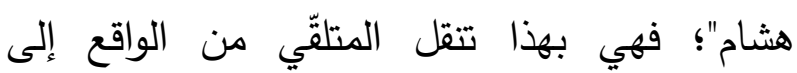
المتخيّل، ومن الحاضر إلى الماضي، وهكذا يعبر

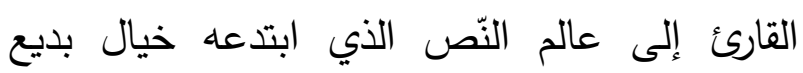

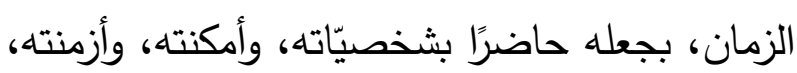
ثمّ أخذ يحشوه بما شاء من أحداث متسلسلة، وصراعات مختلفة تتّصل بطبائع عصره، خاصّة فيما منّاء يرتبط بعالم الكدية والاحتيال، بجانب عالم السخرية

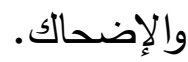
لقد قدّم نصُّ المقامة للقارئ مشيرات حيّة تنبض

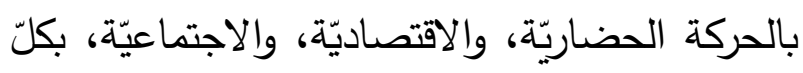

(1) ينظر : مبروك، عبدالله، ضباب، نظرية الاتصال الأدبي بين التنظير

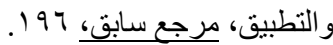

وما ذلك الوصف الذي أمدّنا على هيئة هذا البدوي الذّاخل إلى المدينة، وعلى أحواله، ونفسيته، وشينًا

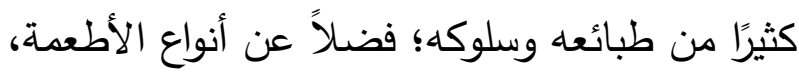

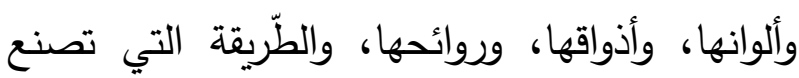

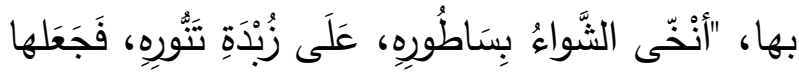

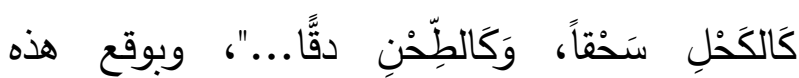

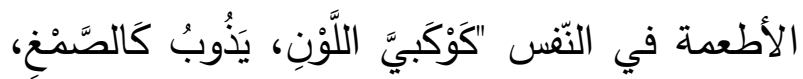

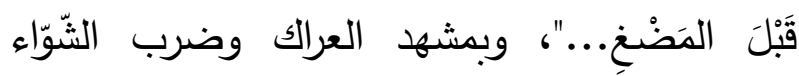
للسّوادي في آخر النّص، وما فيه من زيادة في

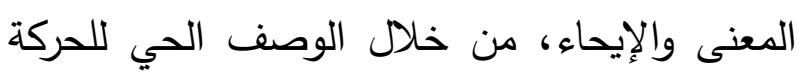

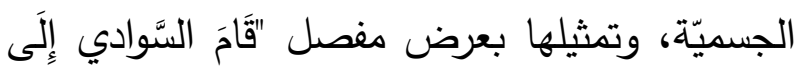

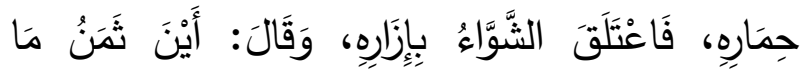

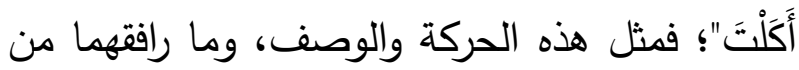

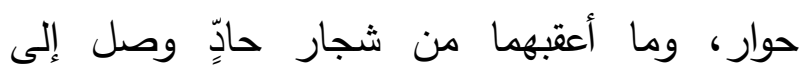
الضّرب، كلّ ذلك من شأنه إحداث مشاركة وجدانيّة

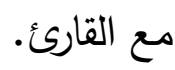

لقد كثفت الجمل السرديّة التي حملت الوصف المكاني -مثلاً- العديد من الأبعاد الحضاريّة للمكان والإنسان، وبذلك يمكن ربط العلاقة ما بين الصّورة الحضاريّة في النّص، والطبيعة البشريّة لشخصيّات ونيّات

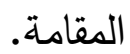
فققول عيسى بن هشام على سبيل التَشَيل: "اشنَتَهَيُُْ"؛

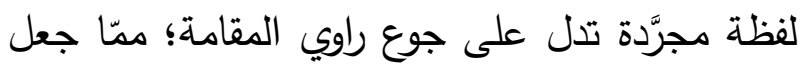
الأنماط السرديَّة في المقامة تتشكَّل وفقًا لمفتاح

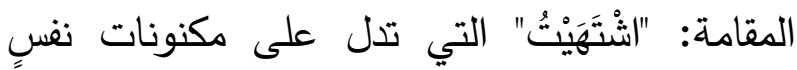

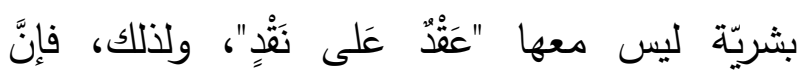


للقارئ أن يسافر عبر النّص، كاشفًا بذلك كثرة

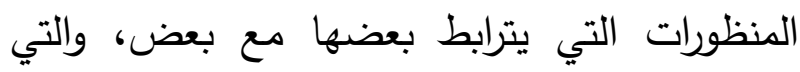
تعدَّل كلمّا حدث انتقال من واحد منها إلى الآخر (؟). ومثل هذه القراءة تعمل على بناء التألق ما بين التى لاحن

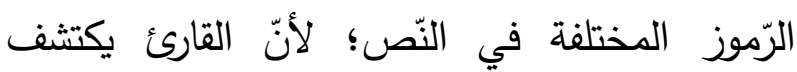

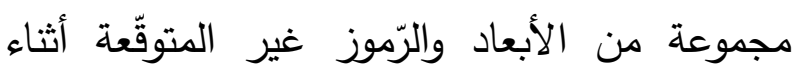

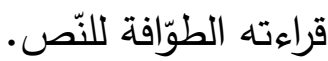

وهذا ما يلاحظ في علاقة عيسى بن هشام بالسّوادي؛ كونها تشي إلى رمزين؛ الأوّل رمزٌ يتعلّق

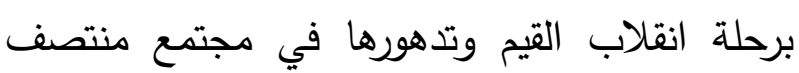
القرن الرابع الهجري، حينما أصبحت الكدية وسيلة من وسائل التّحايل والارتزاق = ابن هشام، والثاني

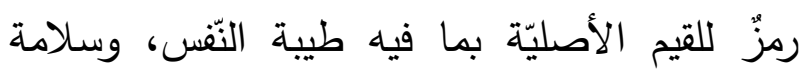

$$
\text { القلب = السّوادي. }
$$

فإن كان الهمذاني يسعى إلى رسم حوار بين الثخصيتين الرئيستين في أحداث المقامة، فهو يقدّم

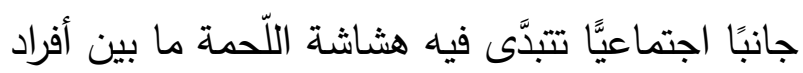

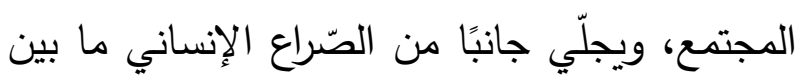

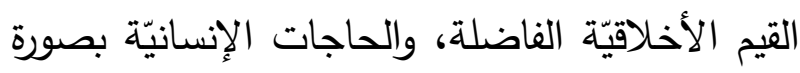

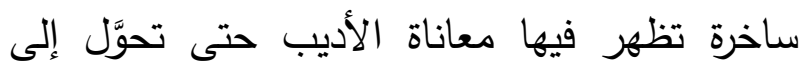
صعلوك تسوقه النّقمة، وتحدوه الحاجة، ومن خلالها يسوِغ الهذاني طريقة الكدية، ويبسط بالتّالي طرق وندون

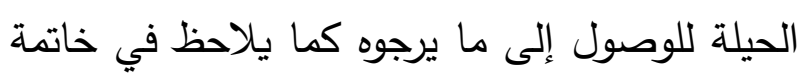

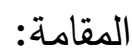

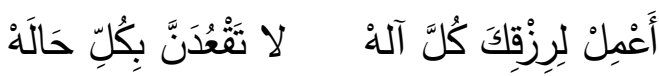

ما فيها من تتاقضات وممارسات، وشخوص وصراعات، وفق مركة نصّ المقامة الزمانيّة والمكانيّة، والإنسانيّة، فكأنّه عين بآلة تصوير تقدّمها للرائي، من خلال بؤر راصدة لجميع حركات

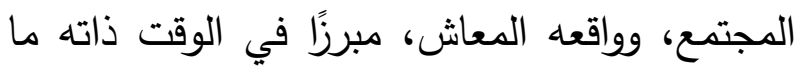
أصابه من خلخلة طالت بنيته، فغدا النّص محمّلاً

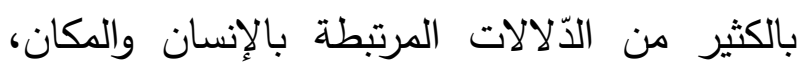

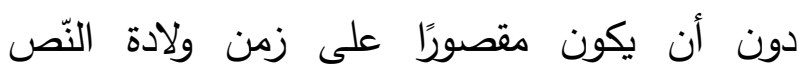

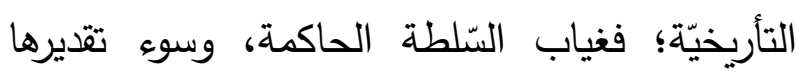

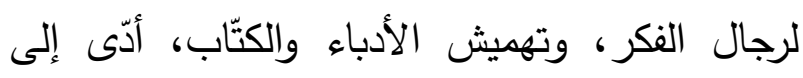

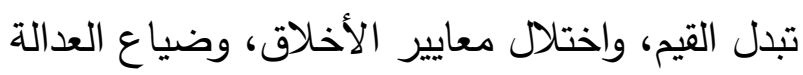
الاجتماعيّة في توزيع الثّروة، وهو ما أنتج طبقتين والتين

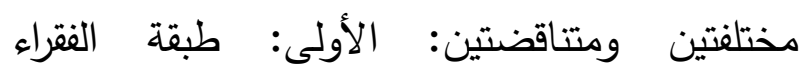
والمحتاجين. والثانية: طبقة الأغنياء والمترفين. ع - و- البعد الجلأي ونعني به جدليّة التوقّع والذاكرة، أو وجهة النّّر

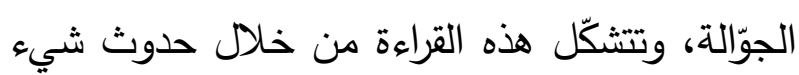

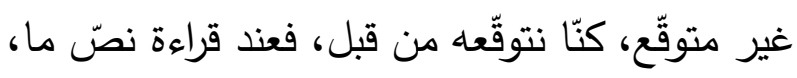
فنحن نمضي على نحو متّصل في تقويم الأحداث

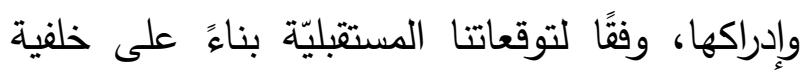
الماضي ('). ولذلك؛ فإنّ حدوث شيء غير متوقَّع من شأنه، أن

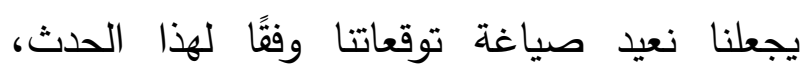
بالتالي نعيد تفسير المعنى الذي نسبناه إلى ما سبق لتقاعل وقوعه، وعلى هذا؛ فإنّ وجهة النّظر الجوّالة تتيح 
سواء على مستوى اللفظة المفردة، أو من خلال معانيها ودلالاتها؛ فالبدء بالأعاء بوصفه تحيّة، والتحيّة سلوك اجتماعي لله دور علائقيّ ما بين الطرفين، كونها تذيب الجليد ما بين طرفي التّاعل

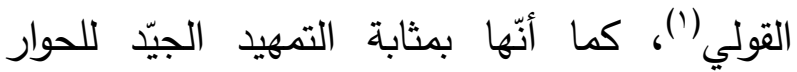

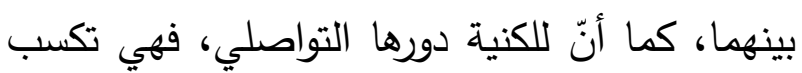

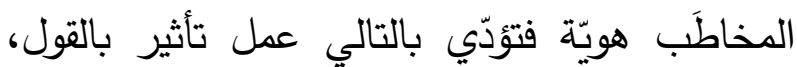

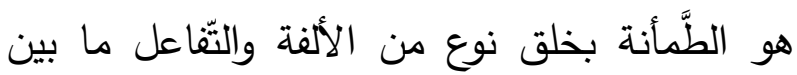
المتكلم والمخاطَب. وهي أعمال تشارك في إنجان نوع النهاز آليّة السيّؤال، وأدوات الدّعوة (؟). والملاحظ أنّ عيسى بن هشام بدأ بطرح السؤال

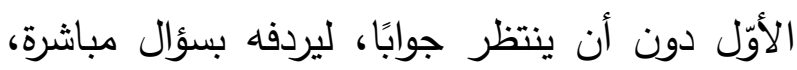

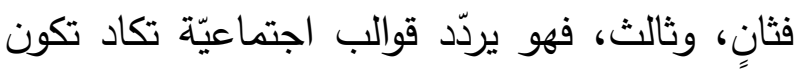
محفوظة، تقتضي معرفة مسبقة ما مان بين المتخاطبين (r). ولعلّه يسعى من خلال ذلك إلى تحقيق الإيهام بأمرين؛ أوّلهما: الامتثال للأعراف الاجتماعيّة في لهي مقام لقاءِ مَن تربط بينهم سابق معرفة، وثانيهما:

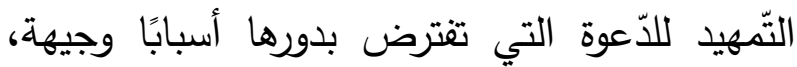
منها ما تكثّلت باه التحيّة بمكوّناتها من كنية، وأسئلة تطرح على المعارف من الأشخاص. ومنها ما يقدّمه بهـ

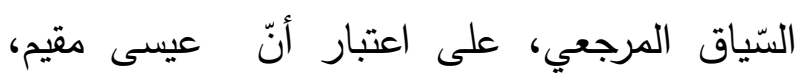

(1) ينظر : العمامي، مقاربة النص السردي النخييلي من وجهة تداولية، مرجع سابق.

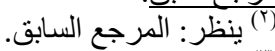

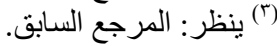

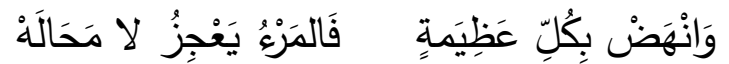

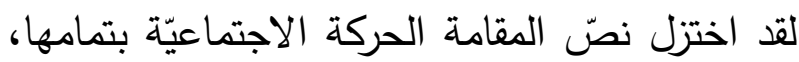
فقد انتقل من مجرّد ظهور الرّغبة في تتاول الطعام

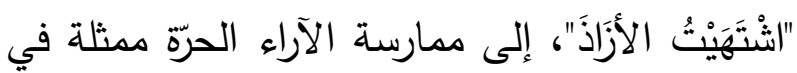

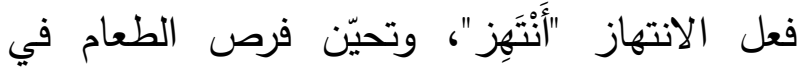

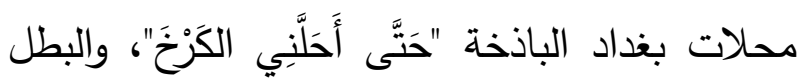
مع ذلك فقير معدم "وَلَيِسَ مَنْي عَقْدُ عَلى نَقْدِ".

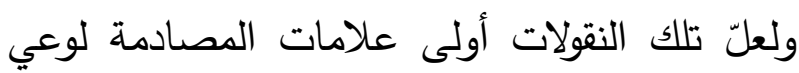

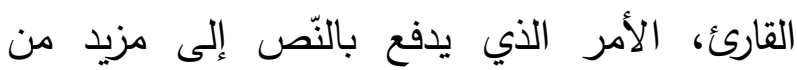

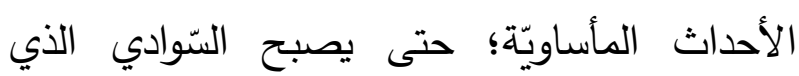
"يَسُوقُ بِالجَهِْْ حِمِارَهُ" أوّل ضحايا في النّص.

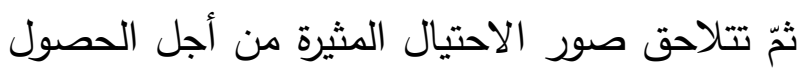
على لقمة عيش، ويالها من صرخة حادّة قويّة مدوّية

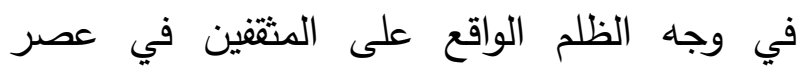
المؤلّف، وهذا بدوره ما أثر عن مضمون ذلى ذلك الشعر في آخر النّص.

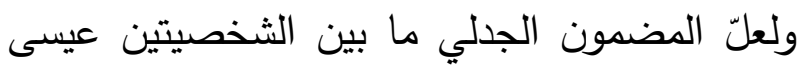
بن هشام والسّوادي يبدو جليَّا ضمن تقديم الكثير من

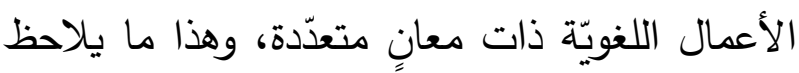
في بعض أقول عيسى بن هشام المحمّلة بالكثير من السلوكيّات الدينيّة، والأعراف الاجتماعيّة، فهناك لئك الدعاء: "حيّاك الله"، والتكنية "أبا زيد"، فضلاً عن الاعنيّة

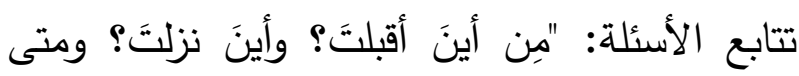

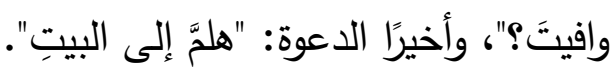
وبهذا استطاع عيسى بن هثام إقامة جسر من العلاقة، من خلال بعض الأعمال اللغويّة المنجزة، هلهن 


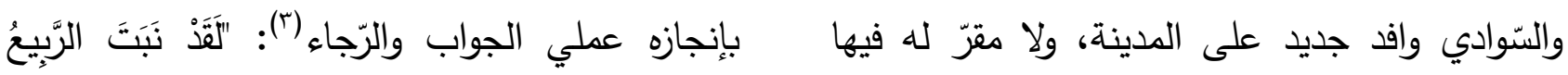

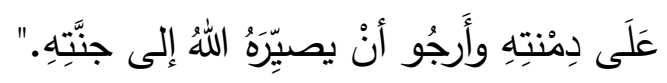

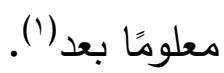

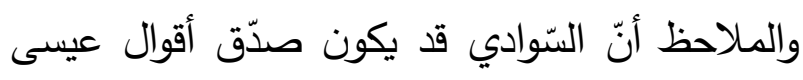

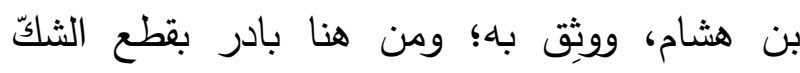

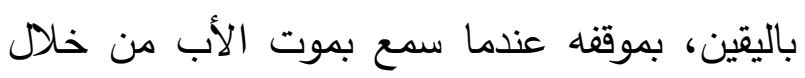

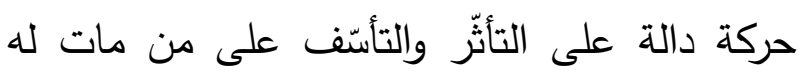
قريب، أو عزيز إلى النّفس. ومن هنا استطاع ابن هشام تضييق الدائرة على الى لئى

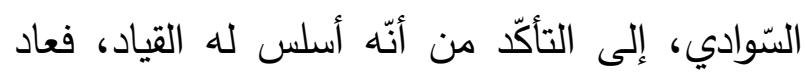

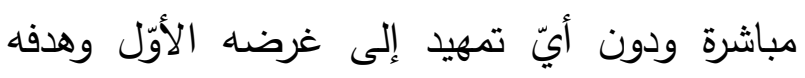

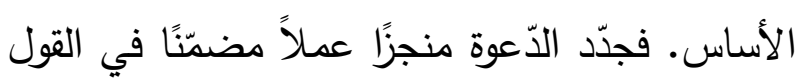
مباشرًا هو التّخيير، وعمل تأثير بالقول هو الإجبار.

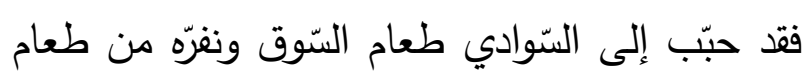

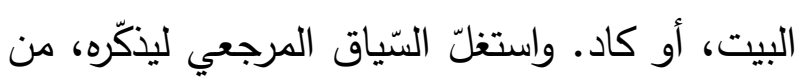

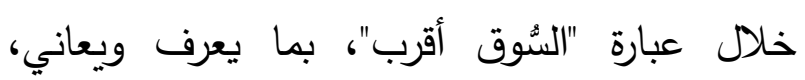
إرهاقه وجوعه. وأوحى إليه، في الآن نفسه، بطول

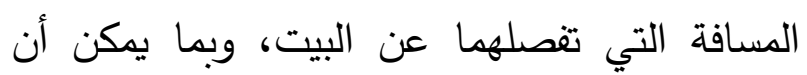

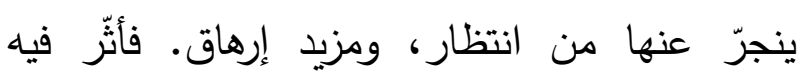
بالقول، وأسال لعابه، وأفقده القدرة على الكلام. فمال

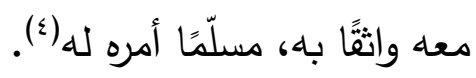

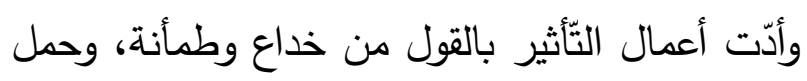

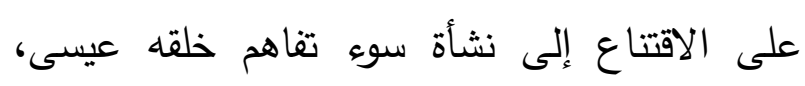
ولعله سيسعى إلى تعميقه. فما دام سوء التفاهم

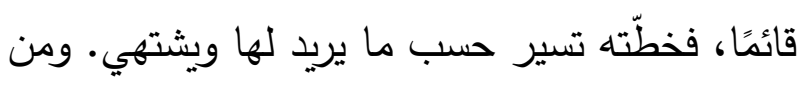

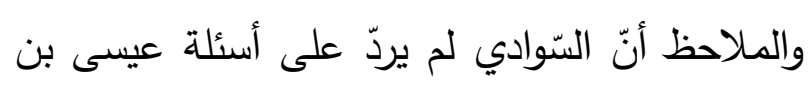

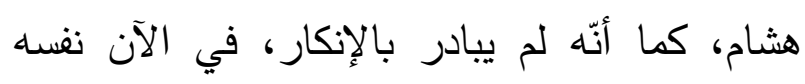

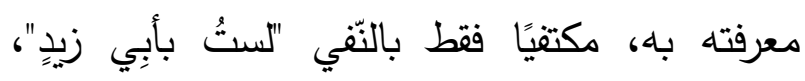
واقتصر بالقول: "ولكنّي أبو عُبيد". والملاحظ -أيضًا - أنّ عيسى بن هشام استطاع من الن

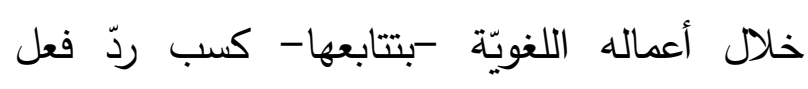
السّوادي، ومن ثمّ دفعه في الاتِّجاه الذي يحبّنِه ويسعى إليه، ولهذا استطاع توظيف كلّ ذلك في مصلحته؛ ليحصر كلامه في موضوع العلاقة ولة

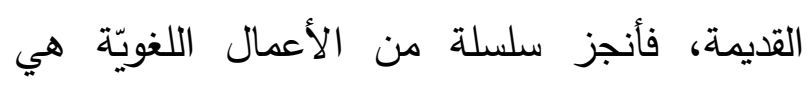

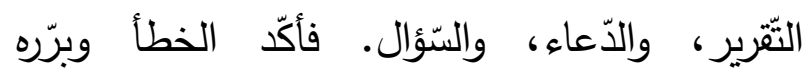
بالنّسيان، ودعم المعرفة السّابقة بالسّوادي بالسئوال: والئ

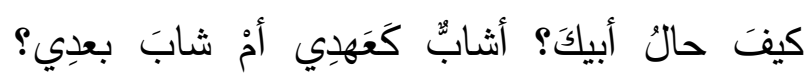
وللسئوال هنا وظيفة حجاجيّة، إذ يهدف إلى إقناع

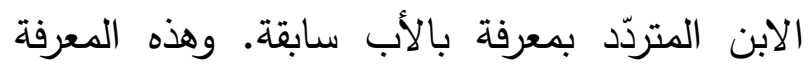
ليست معطىً من معطيات خطاب عيسى؛ وإنّما هي مضمّنة فيه(r). وقد أثمرت أعمال عيسى بن هثام اللغويّة، وأدّت المنتظر منها. وهو عمل تأثير بالقول يمكن تسميته بزرع الثّّة في نفس السّوادي. وقد زال شكّه، وانخرط في الحوار طبقًا لخطّة عيسى بن هشام. وذلك ولك (1) ينظر : المرجع السابق. (1) 
ع - الب-ه البعد الوظيفي

يتمثل البعد الوظيفي للقراءة الإستراتيجيّة في جعل المألوف غريبًا، وذلك من خلال مستويين هما:

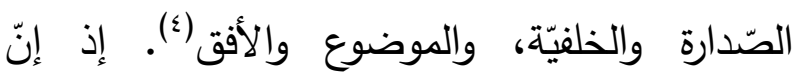

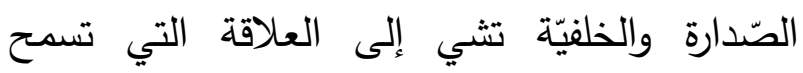
لعناصر معيّنة بأن تبقى في الخارج، في حين ترتدّ لعند

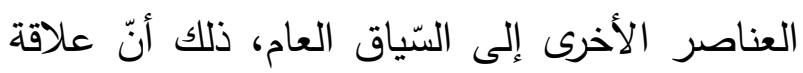

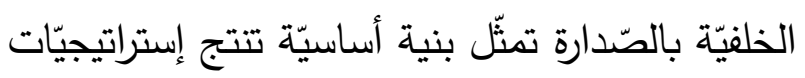
النّص عن طريقها توترًا يفجّر سلسلة من الأفعال

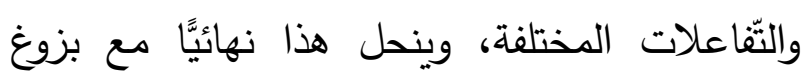

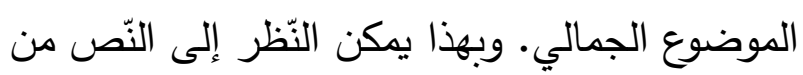
منظورين؛ الأوّل يرتبط برؤية النّص في ذاته، والثاني يتعلّق برؤيته في إطار سياقه العام.

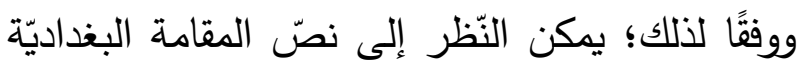

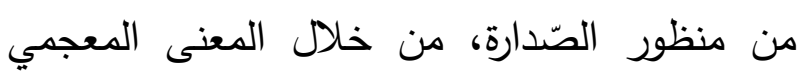

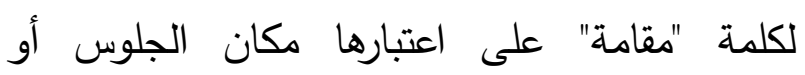
المجلس، وكذا الحال في المعنى المباشر لكلمة "البغداديّة" المنسوبة مكانًا إلى مدينة بغداد بالعراق،

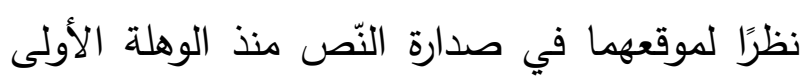

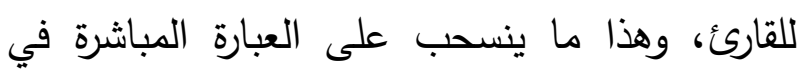

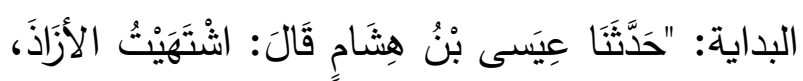

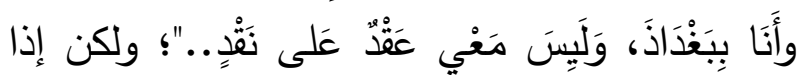

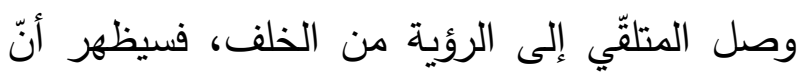
خلف عيسى بن هشام يختفي الهذاني، باعتباره

(؛) ينظر : مبروك، من صوت الذات إلى سلطة النص، مرجع سابق،

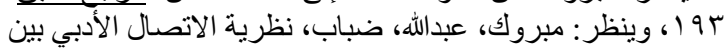

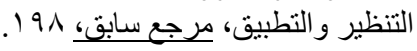

زاوية التلقي يستدعي العمل غير المباشر سيناريو

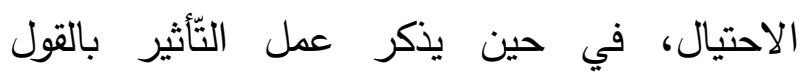
بسيناريو الضّيافة. فهل سيظلان متراكبين إلى نهاية المقامة؟ أم هل سينفصلان؟ وكيف؟! ('). الملاحظ أنّ عيسى بن هشام هو مَن تكلّم، ومَن حدَّد

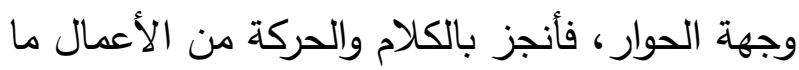
يمكن أن يسير به قُدمًا نحو الغاية المنشودة، في حين يلاحظ أنّ السّوادي أصبح مجبرًا - -دون أن

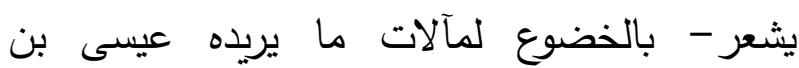

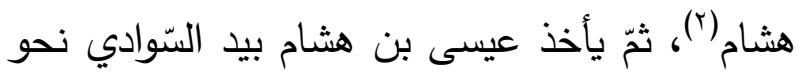
سوق الأطعمة، ويتحدَّث إلى الثَّوّاء فينجز أعمالاً لغويّة ذات صيغة مباشرة هي الطّلب: "افْرِزْ لأبِي

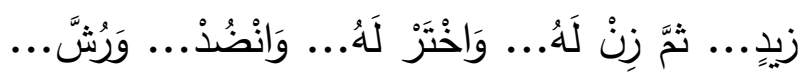

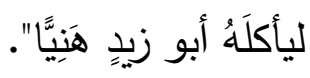
فجملة تلك الأعمال اللغويّة أنّها أعمال ناجحة، بناءً

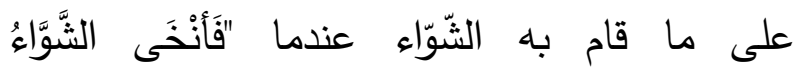
بََِاطُورِه..."، وقد أجاد ابن هشام، فتحكّم في الكلام،

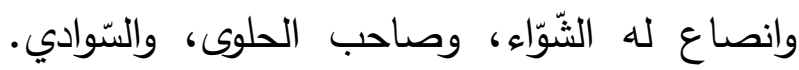

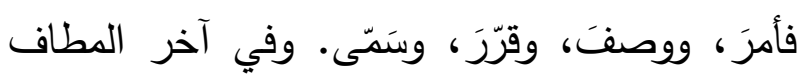

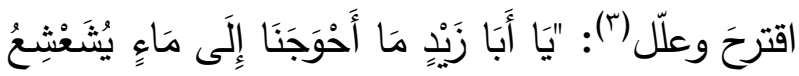

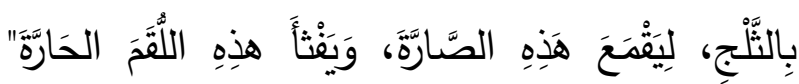
صدَّقه السّوادي، وبقي ينتظر الماء. 
الأديب قُرَيدًا لِيكسب قوت يومها: "كَْْ قُلْتُ لِذَذَكَ القُرَيْدِ؛ ولكن في ثوب من السخرية والإضحاك....؛؛

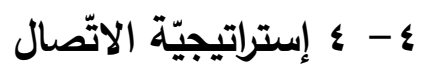
ويعنى بها عمليّة التواصل التي تتمّ ما بين النّص

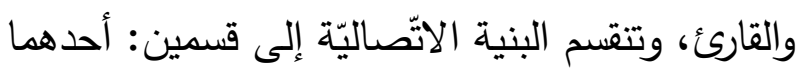
يطلق عليه الآتِصال المتعادل ما بين النّص والقارئ، والآخر يطلق عليه الآتِصال المنحرف ما بين النّص

والقارئ(')

ع - - - 1 الاتِّصال المتعادل

ويقصد به توافق الرؤية ما بين النّص والقارئ، أي الئي

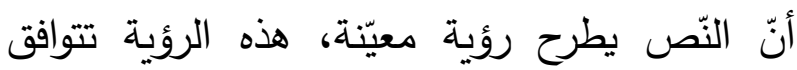

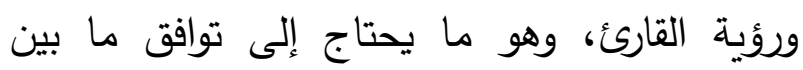
الرؤية والأداة في النّص. فإذا توافقت الرؤية الفكريّة

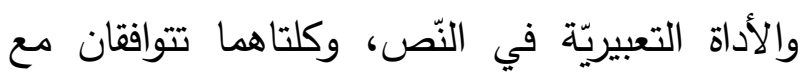
رؤية القارئ، كان الاتِّصال متعادلاً بينهما (؟).

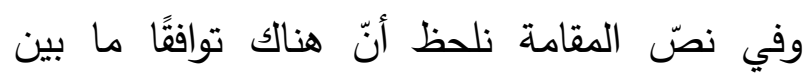

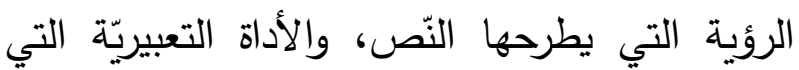
اشتغل عليها، ولعلّ الحالة الثعوريّة والتَّأثير اللذين

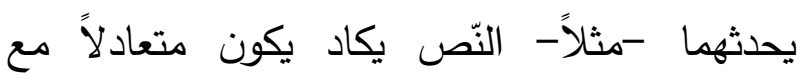
الحالات الشعوريّة التي يشعر بها المتلقّي؛ انطلاقًا

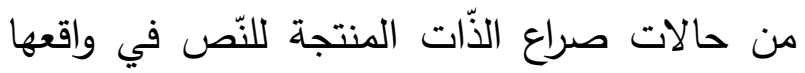

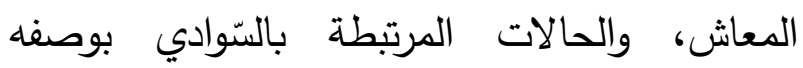
الشخصيّة المركزيّة في النّص.

(1) ينظر : مبروك، عبدالله، ضباب، نظرية الاتّصال الأدبي بين التنظير

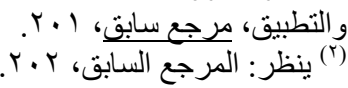

الباثّ الأوّل للخبر، وصانع الحدث؛ لأنّه صاحب الأب الذّور الفاعل منذ العنوان، بوصفه النواة التي تختزل النّص، وتوحي بمراميه من جهة، ومن جهة أخرى للأل على اعتبار العنوان وظيفة تأثيريّة تقبل التّحفيز لاكتشاف النّص من خلال تأسيس دافعيّة تغري تأيريه تئيل القارئ وتستقزه منذ البداية، بتوجيه المتقبّل نحو نتيجة يضمرها صاحب النّص، بدليل ما يمكن ملاحظته في عمل "الإسناد" -مثثلاً- حينما عمل على قواعد لئل السّند، وشروط الضّبط والعدالة التي اشترطها المحدّثن لرواية الحديث، فكأنّ الهذذاني مع ذلك يهزأ بالإسناد؛ ولكنّه يشتغل عليه بغية المحاكاة لران

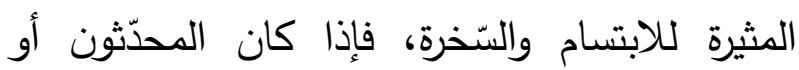
الحديثيّون يسقطون رواية المجهول؛ فإنّ صاحب النّص في الأدب يجيزها، ويسند حكاية الحدث إلى لى لئل

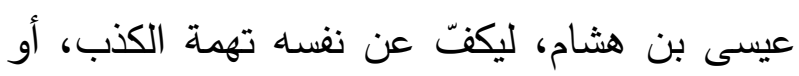

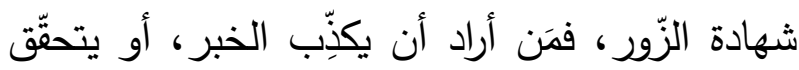
من صحة وقوعه، فعليه مساءلة عيسى بن هشام.

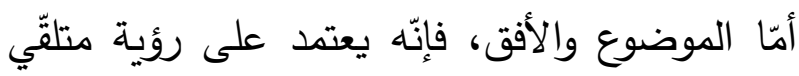
النّص أو قارئه، فله أن يختار منظوره الخاصّ ليصل لئند

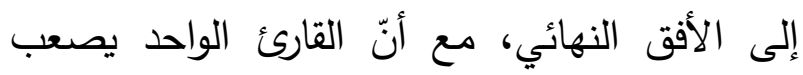

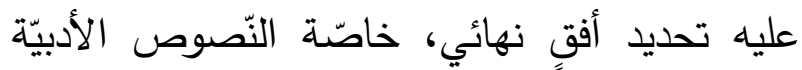

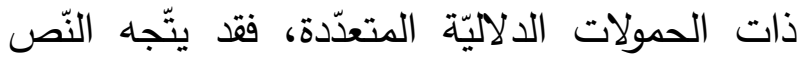

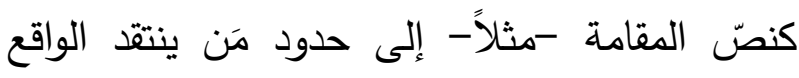
المعاش، في ظلّ اختلال موازين السّلطة، وإهمال المكانة المرموقة لأهل العلم والأدب، خاصّة في في في منتصف القرن الرابع الهجري، بعد أن استحال 
ولهذا الانحراف أسباب، منها عدم إدراك القارئ لفهم

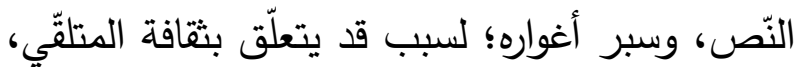

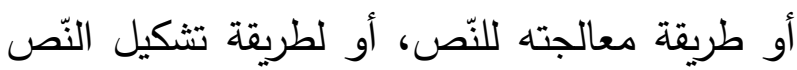

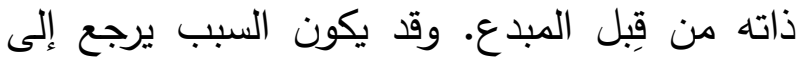
غياب السّياق الضّابط ما بين النّص والقارئ، أي الي

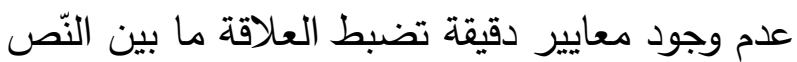
والقارئ. وسبب ثالث يتمثّل في الثراء الدّلالي الكثيف لئن

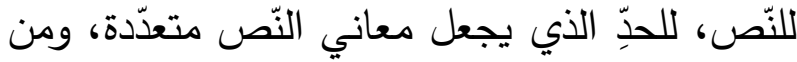
ثُّ، تتعدّد الرؤى النقديّة للقارئ، فيحدث الانحراف

$$
\text { الاتِّصالي، ومن ثمّ الدّلالي (r). }
$$

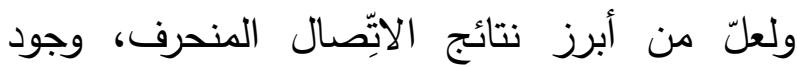

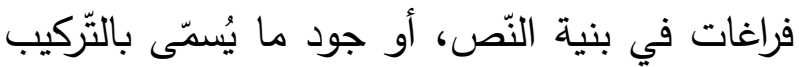

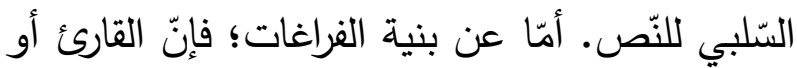

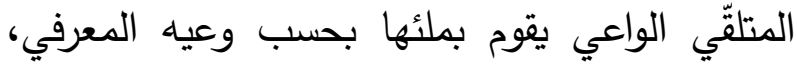

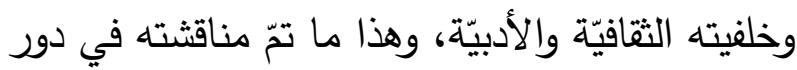
القارئ. أمّا التركيب التّلبي للنّص، فإِّنه ينقسم إلى قسمين:

$$
\begin{aligned}
& \text { r- r (1-) مقوّمات الترّكيب الستّلبي. } \\
& \text { r- r - وظائف التّركيب التّلبي. }
\end{aligned}
$$

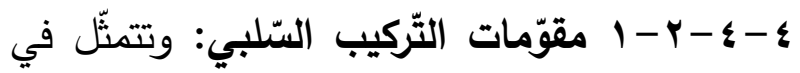
المقوّم الثّكلي، والمزدوج، والمجاوز للعالم.

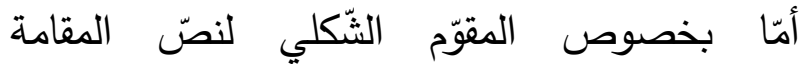
البغداديّة، فالملاحظ أنّ النّص يقوم على: 1- البناء النثري التقليدي. r- الاعتماد على السّجع، والجمل القصيرة. (1) ينظر : المرجع السابق، نس الصفحة.
فحالات الفقر، والجوع، والفاقة، والحاجة؛ كلَها صراعات وجوديّة تعتور الإنسان في كلّ مكان وزمان، وهذا بدوره ما يدفع المتلقيّي بالتفاعل الوجداني والعاطفي والإنساني مع شخصيّة السّوادي؛ بوصفه لئه الضحية الأكثر تأثرًا وتأثيرًا في النّانَ، ولعل المشاركة التفاعليّة مع السّوادي تكاد تتضّح بشكل لافت خاصَّة في نهاية النّص حينما "قامَ السَّوادي

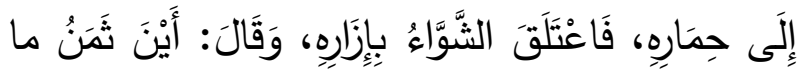

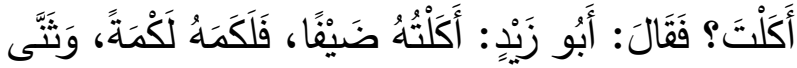

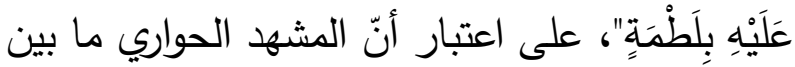

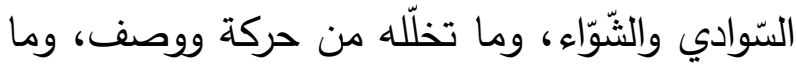
أعبهها من ضرب وعرالك بالأيدي شكّلا صورًا متتالية مثيرة، من شأنها إحداث مشاركة وجدانيّة من جهة القارئ، وهذا ما يمكن وصفه بالمعادل الموضوعي الذي طرحها ت.س. إليوت حينما تحدَث تصن الحالة الثعوريّة والدلاليّة المطروحة في النّص تأثيرًا متبادلاً في المتلقّي بالرؤية نفسها التي طرحها النّص(') צ- ـ - ب الاتِّصال المنحرف

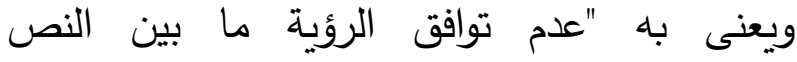

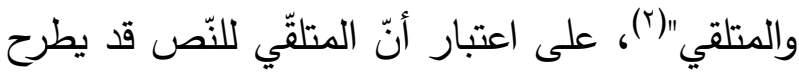

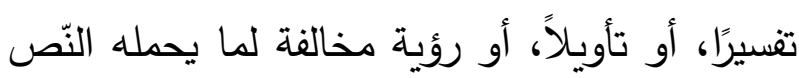
من المعاني والدّلالات قد لا يكون بالضرورة متوافقًا والرؤية التي يطرحها النّص.

\footnotetext{
(1) يظرك : مبروك، من صوت الذات إلى سلطة النص، مرجع سابق، 197.

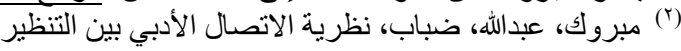
و التطبيق، مرجع سابق ب r. r.
} 
؟ - ؟ - - - وظائف الترّكيب السّلبي

تتمثل وظـائف التركيب السلبي في ثلاثة جوانب؛ هـي: خاصـيّة التقـويم الأدبـي، والقـوة الأساسـيّة

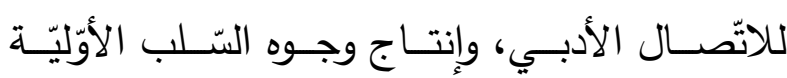
والثّانويّة (1).

أمّا فيمـا يتعلّق بخاصية التقويم الأدبي، فالملاحظ أنّ النّص يتشكّل من مجموعة من الخواص الأدبيّة

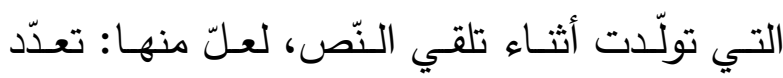

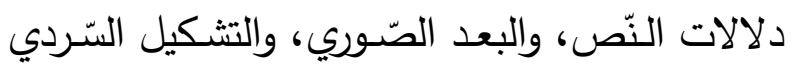

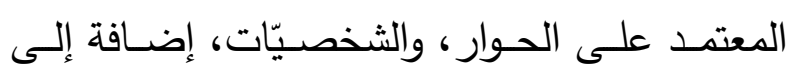

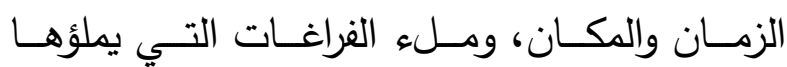
المتلقّي.

أمّا القوّة الأساسيّة للاتّصال الأدبي، بوصفها عنصرًا

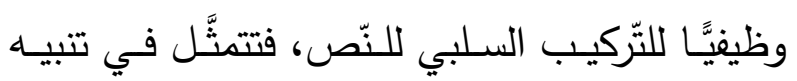
القارئ لعناصر مخبوءة لم تتم صياغتها بعد في للتئي النّّص الأدبـي، ومنهـا يبحـث القـارئ في آليّات

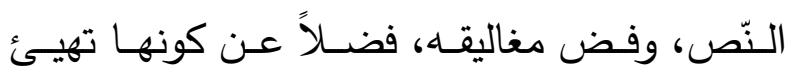

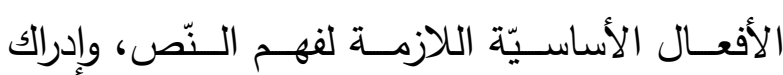

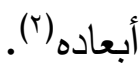

أمّــا فيمـا يتّصـل بعمليـة السّلب التي يعتمــ عليهـا

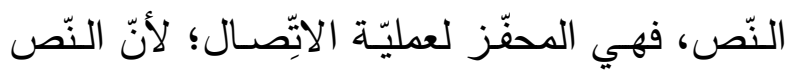

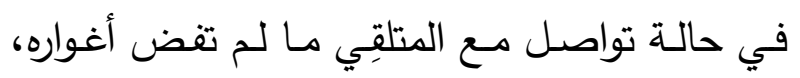
وتكثف معانيه، فإذا كثفت جميعها توقّقت عمليّة

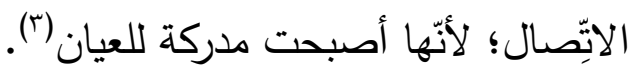

r- الاتِكَاء على المشاهد الحواريّة، والصّور المتتالية. ع - توظيف الاقتباسات القرآنيّة، والأمثال الدراجة. ومع كلّ ذلك؛ فإنّ دلالة النّص تقوم على بنية من

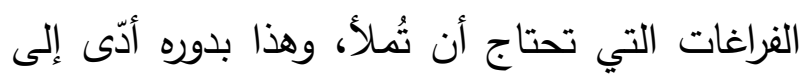

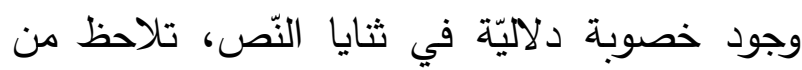
خلال حزمة من الألفاظ والجمل والعبارات، فكأنّما المقامة شاهدُ على عصر الهمذاني وضميره الحيّ الهيّ في وجه التتاقضات المجتمعيّة التي يعيشها الإنسان في منتصف القرن الرابع الهجري.

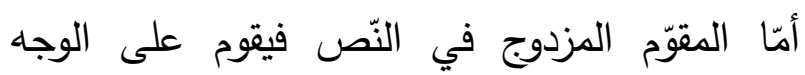
المعكوس الذي صوّره النّص؛ فقد استحالت بؤرة النّص ودلالاته الباطنة، من مجرّد نصٍّ للإضحاك

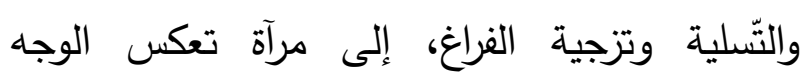
الحقيقي للمجتمع في العصر العباسي خلال القرن الرابع الهجري، وما فيه من صراع وتناقض، وتهميش طال العلماء والأدباء. أمّا المقوّم المجاوز للعالم فيتمثّل في أنّ ما لم تتم صياغته هو ما لم يفهم بعد، وهذا يتّضح من خلال

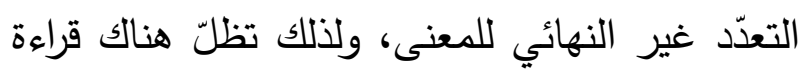
في النّص لم يتم اكتشافها بعد، كون اللغة في هذا

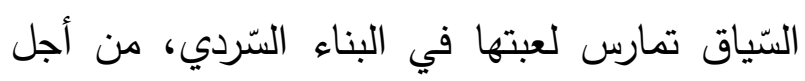

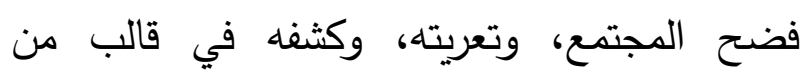
التشكيلات القوليّة. 
ذلك دراسة محمد نجيب العمامي "مقاربة النَّص السرديّ التخييلي من وجهة تداولية: المقامة البغدادية للهمذاني أنموذجا"، التي صدرت ضمن كتابه "بحوث في السّرد العربي، مكتبة علاء الدين، تونس، 0. . بر"، ولهذا سنقف على هذه الدراسة، بوصفها ارتدادًا عكسيَّا غير مباشر • يبدأ العمامي مقاربته التداوليّة بالوقوف عند عتبة العنوان في المقامة، معتبرًا العنوان مركًَّا نعتيًّا طرفه الأوّل يحيل إلى جنس أدبي يخضع لقواعد وإكراهات بنائية مخصوصة، باعتباره جزءًا من موسوعة القارئ المتعاون. أمّا الطرف الثاني فيحيل إلى مكان يرجّح القارئ، اعتمادًا على كفاءته الموسوعيّة، وتحديدًا على معرفته بمقامات الهمذاني الأخرى، أنّه مكان

$$
\text { الأحداث المرويّة. }
$$

فبين مقامة الهمذاني وقارئها عقد قراءة، تكوّن خصائص الجنس بنودَه الكبرى، على اعتبار أنّ القارئ -غالبًا - ما ينتظر تحقّق ما توقّع في مستوى مكوّني العنوان، ومستوى البنى الملزمة؛ لأنّ القارئ متلفّظ مشارك ماثل في خطاب المؤلّفَ، والنّص منتوج يجب أن ينتمي مصيره التأويلي إلى آليّه التكونيّة الخاصِّة، ومن هذا المنظور فالمؤلّف والقارئ إستراتيجيّتان نصّيتان لا كائنان تجريبيّان. يتلمّس العمامي الكثير من الجوانب المسكوت عنها في متن المقامة، محاولاً تنشيط التّراكيب من خلال توليد الأسئلة وعرض سيناريوهاتها، فمع نمو الحكاية ينمو التحليل لدى العمامي، فيتأمّل قصة عيسى بن
•- - الارتداد العكسي

يعتبر الارتداد العكسي آخر آليّة من آليّات معالجة النّص، من منظور نظريّة الاتِّصال الأدبي، وهي رد فعل النّص على وعي القرّاء والمتلقِين لله، ويعنى باه النّص الذي ينتجه القارئ، أو المتلقّي للنّص، بناء على وعيه وخلفيته المعرفيّة، وذلك عندما يقرأ نصَّا أدبيًّا بعينه، وينتج بعد القراءة نصَّا آخر نتيجة تأثنّه بالنّص المقروء، ففي هذه المرحلة يتحوّل القارئ أو المتلقيّي مبدعًا نصَّا جديدًا، وقد يكون هذا النّص الجديد عكسيَّا أو توافقيَّا مع النّص الذي قرأه أوّلاً، ومهما يكن من أمر، فإنّ النّص الجديد لا يعدو أن

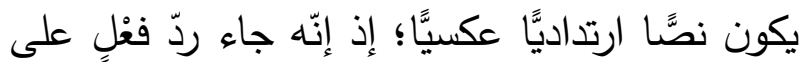
نصٍّ مقروء (') وينقسم الارتداد العكسي إلى قسمين: أحدهما ارتداد عكسي مباشر، وذلك حينما يكون النّص نصَّا يقوم على الإبانة والإفصاح والوضوح، وحينئذ يتشكّل نصُّ عكسي مباشر • وغالبًا ما تكون في النّصوص إن ذات البنية السطحيّة المباشرة كالخطب مثلاً. والآخر ارتداد عكسي غير مباشر "فينتج عندما يتأثر القارئ أو المتلقي بنص أدبي ثري ومتعدد الدلالات"(؟)؛ نظرًا لما يحمله من بنية عميقة، ودلالات موحية، وغالبًا ما تكون الارتدادات العكسيّة دراسة نقديّة تثري النّص، وتتجاوز به حدود بنيته السطحيّة، ومن أمثلة

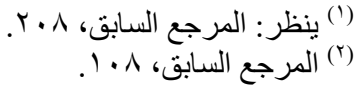


المؤتلف، أو ينِّع داخل المنوال الواحد. وأيَّا يكن

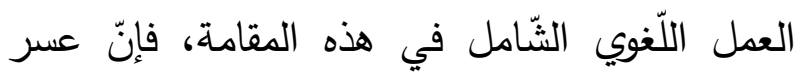
تحديده واختلاف القرّاء على مرّ العصور حول مقاصد تأليف المقامات، وما في النّص من ثغرات

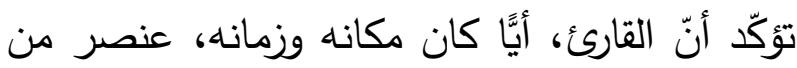
العناصر التكونيّة للمقامة. والملاحظ أنّ التحليل التداولي الذي اشتغله عليه العمامي، له أهميّة في النظر إلى النّص الأدبي، باعتباره فعلاً تواصليَّا، وله أهميّة في تأويل الكلام، إنهي

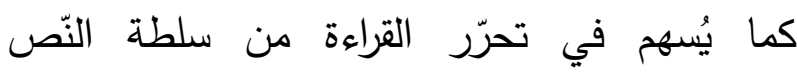
المطلقة، ويخلق حوارًا حقيقيًا بين الذّات المنشئة، والذَّات القارئة؛ ولكنّه في المقابل، أهمل دراسة الخصائص الدلاليّة لنصّ المقامة البغداديّة، كما أنّه اهتمّ بمقاصد القول، وأغفل طرائق القول. كما أنّ المنهج التداولي لا يفي بتحليل خصائص النّص وبواعثه، كما هو الحال من منظور نظريّة الآتِصّال الأدبي، التي استطاعت -بفضل هول معطياتها

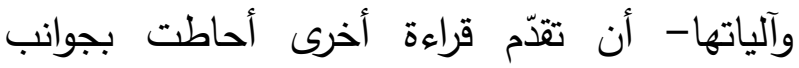
بالنّص؛ بدءًا من الرؤية التكوينيّة للمبدع، مرورًا بالخاصيّة النّصيّة، ثمّ الوسيلة التواصليّة؛ ودور لرئه القارئ في استكثاف المعنى، ومله الفراغات، وربط

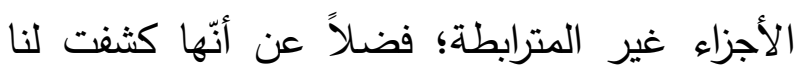
أبعاد إستراتيجيّة القراءة، وما يتبعها من البعد الذّاتي، فماء

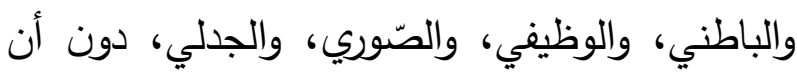
تهمل النظريّة إستراتيجيّة الاتِّصال، التي بدورهاي كثفت عن الآتِّـال المتعادل والمنحرف، ثمّ اكتمل
هشام مع السّوادي، وفق لباس تُحالك فيه خيوط

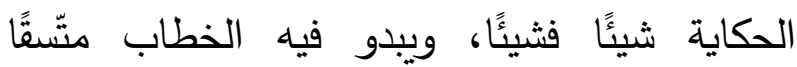

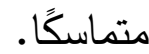

وبما أنّ من مقتضيات التّواصل أنّ إنجاز أي عمل

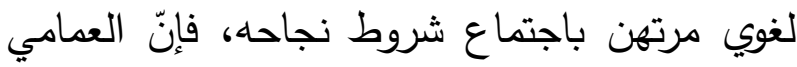
ييني على هذا المقتضى التّّاولي تأويلات مناسبة

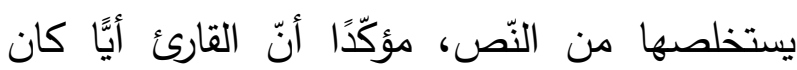
مكانه وزمانه عنصر مهم من العناصر التكوينيّة

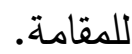

ومع أنّ تحليل العمامي التداولي قد أثبت أهميّته بالنظر إلى النّص الأدبي، بوصفه فعلاً تواصليَّا، وبرهن على قيمة اليّياق في تأويل الكلام، فإنّه لإنه كثف في الوقت نفسه عن الحاجة في تحليل هذا النّص بالذات إلى مزجه بالمنهج الإنشائي؛ لأنّ لهن البّياق لا يمكن أن ينفصل عن الخصائص البنائيّة للخطاب السّردي. وتؤكّد دراسة العمامي أنّ الهمذاني استخدم الثّكل الموروث استخدامًا جديدًا، وقد يكون مبتدع المقامة،

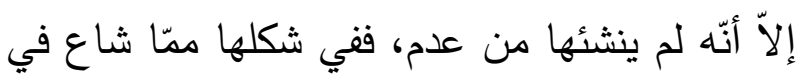

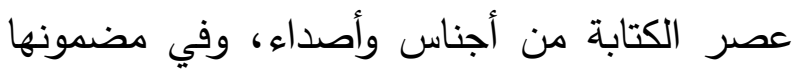
شبه بما حفلت به كتب الأدب من أخبار الشطّار والمتسوّلين، وفيها من العصر الذي أنتجت فيه

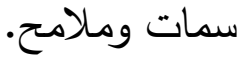
ويشير إلى أنّ المقامة البغداديّة تَنْشّدُ إلى سائر المقامات بأكثر من آصرة، وهذا يحملنا على القول: إنّ الهمذاني لا يصوّر واقعًا؛ بل يُنتج المختلف داخل 
- - كثف النّص عمّا طال منتصف القرن الرابع الهجري من تدهور أخلاقي وقيمي، وهو ما انعكس على مكانة الأدباء والعلماء. - - أبانت إستراتيجيّة القراءة عن البعد الذّاتي، والصّوري، والباطني، والجدلي، والوظيفي للنّص. - يتشكّل البعد الصّوري في النّص من خلال بنية الشخصيّات، ومستويات التعبير سواء كان سردًا، أو وصفًا، أو حوارًا.

- أبرز البعد الباطني للنّص عن وجود طبقتين إحداهما تمثِّل الفتراء والمحتاجين، والأخرى تتشكّل من طبقة الأغنياء والمترفين. - البعد الجدلي للنّص يتمثّل في رمزين أحدهما يعبّر عن انقلاب القيم وتدهورها في منتصف القرن الرابع الهجري، والثّاني يعبّر عن القيم الأصلية.

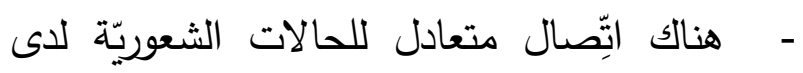
متلقّي النّص، واتّصال منحرف نتيجة بنية الفراغات التي يحملها النَّص.

\section{ثانيًا: التّوصيات}

- - يحفل تراثنا العربي النثري بالكثير من الخصائص النّصيّة التي تحتاج إلى مزيد من العناية والدراسة، في ظلّ تنوّع النظريّات النقديّة الحديثة، ومنها نظريّة الاتِّسال الأدبي. - تعدّ المقامات جزءًا أصيلاً من تراثنا الأدبي، الأمر الذي يدعو إلى مزيد من الذّراسات النقديّة، وذلك من خلال توجيه الباحثين والدّارسين للعناية
عقد النظريّة بالارتداد العكسي سواء كان مباشرًا أو

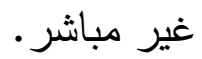
خرجت الدراسة بعددٍ من النتائج والتّوصيات، فيما يمكن إجماله في: أوّاًاً: النتائج - - هناك علاقة قويّة ما بين أبعاد النّص وسياقاته وخصائصها، والرؤية التكوينيّة لبديع الزمان الهمذاني. - تحقّت الكثير من الخصائص النّصيّة في النّص؛ دلالةً وإيحاءً، ومعنَئ، وفراغاتٍ، وتفاعلاً نصيَّا. - وجود علاقة ما بين البنية النّصيّة والبينة الاجتماعيّة؛ نظرًا لما يحمله الواقع من صراعات وتتاقضات. - ق قرّاء النّص ضمنيون؛ بناءً على ما كشفه السّياق التّركيبي، والصّوري، والدّلالي. - البنية النّصيّة كشفت عن ثنائيّة التضاد ما الفقر والغنى، والاحتيال والطيبة، وحياة القرية والمدينة. - - كثفت آليّة استكثاف المعنى عن غياب العدالة الاجتماعيّة، وسوء تقدير السلطة لرجال الفكر والأدب، وأصحاب المواهب. - النّص غني بالمعاني والدلالات ما يستوجب على القارئ القيام بدوره لمله الفراغات، وربط الأجزاء غير المترابطة، وضبط البنتى المتحولة، وتأسيس البنية النهائيّة. - النّص لا يصرّح بماهية الصّراع ما بين توهج الموهبة الأدبيّة، وبين سلبيّة الواقع الاجتماعي. 
- عوض، يوسف، (979 (م)، فن المقامات بين المشرق والمغرب، بيروت: دار القلم.

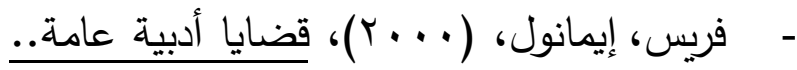
آفاق جديدة في نظربة الأدب، الكويت: عالم المعرفة.

- القاضي، محمد، الخبو، محمد، السماري، أحمد، نجيب، محمد، عبيد، علي، بنخوذ، نور الدين، النَّصري، فتحي، ميهوب، محمد، (· ( • (rم)، معجم السرديات، تونس: دار محمد علي. - مبارك، زكي، (90 باهـ)، النثر الفني في القرن الرابع الهجري، بيروت: دار الجيل.

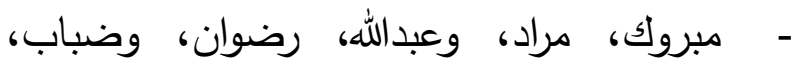

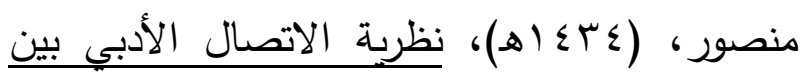

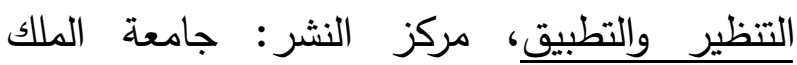

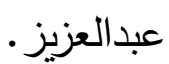

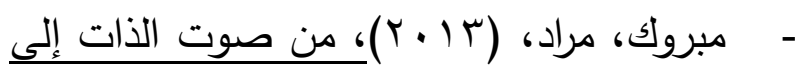
سلطة النص.. قراءة في شعر عبد يغوث الحارثي في ضوء نظربـة الاتصال الأدبي، نجران: نادي نجران الأدبي.

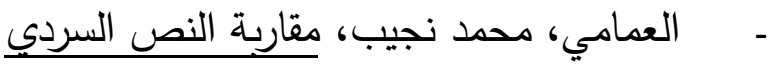
التخييلي من وجهة تداولية: "المقامة البغدادية" للههذاني أنموذجًا. http://webcache.googleusercontent.com/search?q=ca che:mdgdR3Bht4QJ:laamaminajib

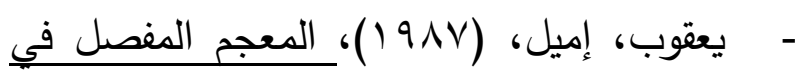
اللغة والأدب، بيروت: دار العلم للملايين.

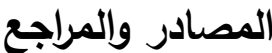

- أمين، أحمد، (979 (م)، ظهر الإسلام، طه، بيروت: دار الكتاب العربي.

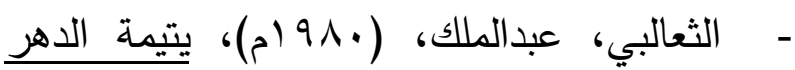
في أهل العصر، تحقيق: محمد محيي الدين عبدالمجيد، بيروت: دار الفكر . - حتي، فيليب، جبور، جبرائيل، جرجي، إدورد،

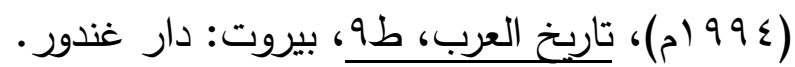
- خلكان، أحمد، (د.ت)، وفيات الأعيان وأنباء أبناء الزمان، تحقيق: د. إحسان عباس، بيروت: دار

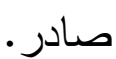
- - الزعيم، أحلام، (99 (م)، قراءعات في الأدب العباسيـ.. الحركة النثريـة، دمشق: مطبعة الاتحاد.

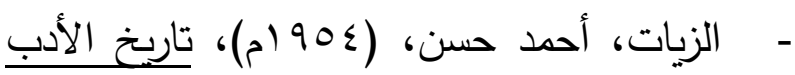
العربي، القاهرة: دار المعارف.

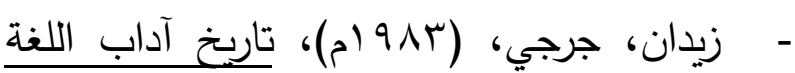
العربية، بيروت: دار الحياة.

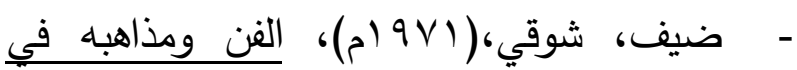
النثر العربي، القاهرة: دار المعارف. القاهرة: دار المعارف.

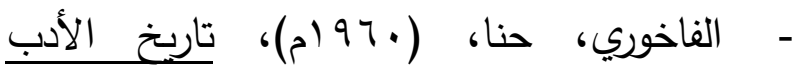
العربي، طا، بيروت: المطبعة البوليسية.

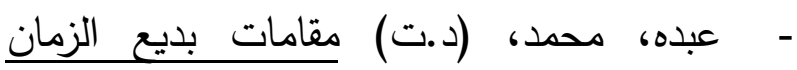
الهمذاني، القاهرة: دار الفضيلة.

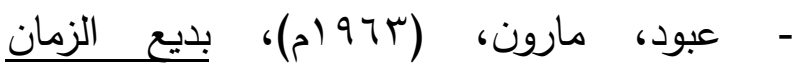
الهمذاني، القاهرة: دار المعارف. ماف، 


\title{
Alhamazani's Baghdadi Maqama: An Applied Critical Study in the light of the literary Communication Theory
}

\author{
Dr. Sari Bin Mohammed AL Zahrani \\ Assistant Professor in Literary Criticism \\ College of Sciences and Arts in Almandaq \\ Albaha University
}

\begin{abstract}
Alhamazani's Baghdadi Maqama in the light of the literary Communication Theory as the text is laden with connotative dimensions, multiple semantic aspects as well as artistic and aesthetic features. The researcher has started with the author's textual creativity denoting social, cultural, and psychological perspectives; handling in the meantime textual features, interactions and structure and communicative channel; ending up with reading and communication strategies and feedback. Besides, the study tackles the relationship between the author as the text creator and the text itself as the mirror of social life in the middle of the fourth Hijri century in accordance with the criteria of the literary communication theory. This is due to the fact that the theory shows interest in the author, the text and the receiver. The paper has reached the conclusion that there is a strong connection between Alhamazani's formative vision and the Textual and social context included in Baghdadi's Maqama depending on the meanings, connotations, symbols and implications included in the text.
\end{abstract}

Key Words: Baghdadi Maqama-literary communication theory 